\title{
EFEITO DO DESLINTAMENTO A FLAMA SOBRE A QUALIDADE FISIDLÓGICA E SANIDADE DE SEMENTES DE ALGODXO
}

\author{
Flávia Rodrigues Alves Patricio \\ Engentieira Agrônoma
}

ORIENTADOR: PROF. DR. JOSÉ OTÁVIO MACHADO MENTEN

Dissertação apresentada à Escola Superior de Agricultura "Luiz de Queiroz". da Universidade de são Paulo, para obtencão do titulo de Mestre em Agronomia, Área de Concentração: Fitopatologia.

PIRACICABA

Estado de São Paulo - Brasil

Dutubro - 1991 
Ficha catalográfica preparada pela Seção de Livros da Divisão de Biblioteca e Documentação - PCAP/USP

Patricio, Flávia Rodrigues Alves

314 e Efeito do deslintamento a flama sobre a qualidade fi siológica e sanidade de sementes de algodão. Piracica ba, 1991.

122p.

Diss.(Mestre) - ESALQ

Bibliografia.

1. Algodão - Semente - Efeito do deslintamento 2. Algo dão - Semente - Flambagem 3. Algodão - Semente - Qualidade 4. Algodão - Semente - Sanidade 5. Semente - Deslinta mento - Flambagem I. Escola Superior de Agricultura Luiz de Queiroz, Piracicaba 
EFEITO DO DESLINTAMENTO A FLAMA SOBRE A QUALIDADE FISIOLOGICA E SANIDADE DE SEMENTES DE ALGODXO

FLÁVIA RODRIGUES ALUES PATRICIO

Aprovado em 21/11/1991

Comissão Julgadora:

Prof. Dr. José Otávio Machado Menten

Prof. Dr. Eric Balmer

Prof. Dr. Walter Rodrigues da Silva
ESALQ/USP

ESALQ/USP

ESALQ/USP

Prof. Of. José otávio Machado Menten - orientador - 
Aos meus pais

Carlos e Eda

e ao meu esposo

Heitor

DEDICO 
AGRADECIMENTOS

A autora externa seus agradecimentos a todos que de alguma forma colaboraram para a execucão deste trabalho e em especial:

Ao Departamento de Sementes Mudas e Matrizes, da Coordenadoria de Assistência Técnica Integral, pela oportunidade concedida de realizacão do curso de PósGraduacão.

Ao Departamento de Fitopatologia da Escola Superior de Agricultura "Luiz de Queiroz", por possibilitar a participacão no curso de Pós-Graduacão.

Ao Prof. Dr. José otávio Machado Menten, pela orientacão, incentivo e sugestões.

Ao Conselho Nacional de Desenvolvimento Cientifico e Tecnológico (CNPq), pela concessão de bolsa de estudo.

Ao Laboratório Central de Sementes do Servico de Controle de qualidade, pela possibilidade de execucão dos testes.

A todos os funcionários do Laboratório Central de Sementes pelo inestimável auxilio para execucão dos testes. 
As Engenheiras Agrônomas Dirce Bissoli Ortolani e Rosângele B. R. Gomes pela amizade, incentivo e colaboraça na conducão dos trabalhos.

Ao Engenheiro Agrânomo Francisco Grillo Júnior, do Servico de Producão de Sementes de Ibitinga, pela pronta colaboracão na obtencăo e envio das amostras.

A Secão de Algodão do Instituto Agronômico de Campinas, pela utilizacão de seu equipamento para flambagem e pela consulta a seus periódicos.

Ao Engenheiro Agrônomo João Brunelli e aos funcionários da ASPLAN/Informática e à Engenheira Agrônoma Leila Martins pela colaborarão e permissão do uso dos computadores sob sua responsabilidade.

Ao Engenheiro Agrônomo Roberto Usberti pelas sugestões e incentivo para realizacão deste trabalho.

A Pesquisadora Cientifica Maria Aparecida de Souza Tanaka, pela amizade, sugestões e pela revisão deste trabalho.

Ao Pesquisador Cientifico Altino ortolani e à Secão de Climatologia do Instituto Agronómico de Campinas pelo fornecimento dos dados meteorológicos de Campinas.

A Seção de Fitopatologia do Instituto Agronômico de Campinas, pela possibilidade de consulta de seus livros e periódicos. 
SUMARIO

Página

LISTA DE FIGURAS................... vii

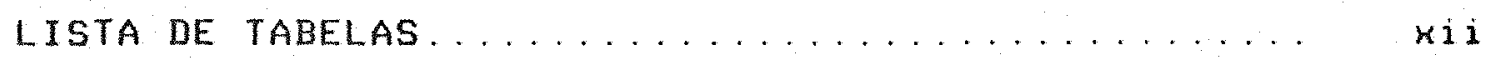



SUMMARY ...........................

1. INTRODUCAO ...................... 1

2. REUISAO DE LITERATURA................ 4

2.1. Caracteristicas da semente de algodão..... 4

2.2. Tipos de deslintamento............. 5

2.3. Efeito do deslintamento sobre a qualidade fisiológica das sementes de algodão....... 9

2.3.1. Germinacão e emergência......... 9

2.3.2. Envelhecimento acelerado......... 11

2. 4. Métodos de deslintamento e separacão por densidade das sementes.............. 13

2.5. Efeito do deslintamento sobre o armazenamento de sementes de algodão.......... 14

2.6. Microrganismos associados as sementes de



2.6.1. Colletotriehum gossyfi.......... 20

2.6.2. Fusarium spp .............. 21

2.6.3. Eotrsodiflodia sp ............. 23

2.6.4. Fhizopus sp ............. 24 
2.7. Efeito do deslintamento sobre a incidência de fungos em sementes de algodão.

2.8. Comportamento de patógenos de sementes de a) godão durante o armazenamento......... 25

2.8.1. Patógenos de campo............. 25

2.8.2. Patógenos de armazenamento...... 27

3. MATERIAL E MÉTODOS................... 30

3.1. Amostras de sementes de algodão.......... 30

3.2. Deslintamento................. 32

3.3. Armazenamento das amostras de sementes..... 33

3. 4. Avaliacões de qualidade das sementes...... 33

3.4.1. Umidade ......................... 33

3.4.2. Germinacão e vigor (emergência em areia) .......................... 34

3.4.3. Vigor (envelhecimento acelerado)... 34

3.4.4. Sanidade................. 35

3.5. Delineamento e análise estatística...... 36

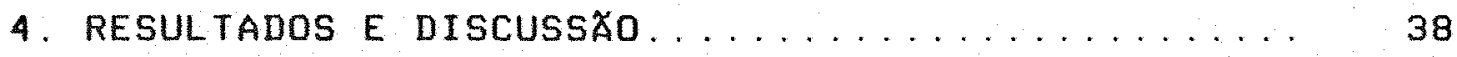

4.1 Umidade........................ 38

4.2. Germinacão e vigor (emergência em areia)... 40

4.3. Vigor (envelhecimento acelerado)......... 56

4.4. Sanidade....................... 65

4.4.1. Colletatrithum gossypii......... 65

4.4.2. Fusariun spp ................ 71

4.4.3. Botrgodiplodiz sp ............. 74 
Página

4.4.4.Aspergillus spp ............. 82

4.4.5. Fentilitiun spp ........... 89

4.4.6. Discussão geral .............. 95

5. CONCLUSŏ́S........................ 9

REFERENCIAS BIBLIOGRÁFICAS ............... 100 
LISTA DE FIGURAS

Página

Figura 1. Dados meteorológicos (Decendiais), coletados na cidade de Campinas, de umidade relativa média e temperatura média, do periodo de janeiro de 1988 a julho de 1989, fornecidos pela Secão de Climatologia do Instituto Agronômico de Campi-

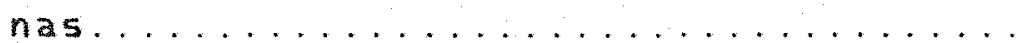

Figura 2. Umidade das sementes de algodão (Método da Estufa, $24 h$ a $105^{\mathrm{co}} \mathrm{C}$ ), da cultivar IAC -19. submetidas a dois tipos de deslintamento e avaliadas a cada três meses. durante o armazenamento por 18 meses em condicões de ambiente não controlado...

Figura 3. Umidade das sementes de algodão (Método da Estufa, $24 h$ a $105^{\circ} \mathrm{C}$ ), da cultivar IAC -20. submetidas a dois tipos de deslintamento e avaliadas a cada três meses. durante o armazenamento por 18 meses em condicões de ambiente não controlado...

Figura 4. Germinação de sementes de algodão, das seis amostras da cultivar IAC-19, submetidas a dois tipos de deslintamento e armazenadas por 18 meses, com avaliacão 


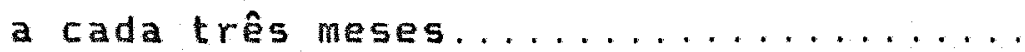

Figura 5. Germinação de sementes de algodão, das seis amostras da cultivar IAC-20, submetidas a dois tipos de deslintamento e armazenadas por 18 meses, com avaliąão a cada três meses..................

Figura 6. Germinacão de sementes de algodão, das cultivares IAC-19 e IAC-20, submetidas a dois tipos de deslintamento, durante o armazenamento por 18 meses em condicões de ambiente não controlado.

Figura 7. Germinacão de sementes de algodão, com germinação inicial maior e menor que $85 \%$ submetidas a dois tipos de deslintamento, durante 0 armazenamento por 18 meses em condicões de ambiente não contro-

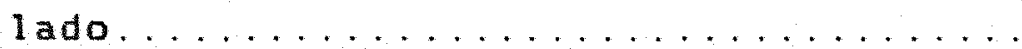

Figura $\mathrm{B}$. Emergência em areia de sementes de algodão submetidas a dois tipos de deslintamento e armazenadas por 18 meses, com



Figura 9. Envelhecimento acelerado das sementes das seis amostras da cultivar IAC-19, submetidas a dois tipos de deslintamento e armazenadas por 18 meses, com avalia- 




Figura 10. Envelhecimento acelerado das sementes das seis amostras da cultivar IAC-20, submetidas a dois tipos de deslintamento e armazenadas por 18 meses, com avalia-

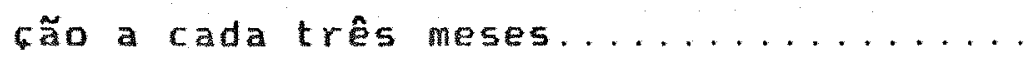

Figura 11. Incidência de calletotrichum gossupii em sementes de algodão, nas amostras da cultivar IAC-19, submetidas a dois tipos de deslintamento, durante o armazenamento por 18 meses em condicões de ambiente

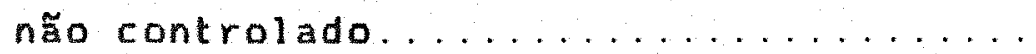

Figura 12. Incidência de Colletotrichum gossgrizi em sementes de algodão nas amostras da cultivar IAC-20, submetidas a dois tipos de deslintamento, durante o armazenamento por 18 meses em condicões de ambiente



Figura 13. Incidência de Fusariur spp. em sementes de algodão nas seis amostras da cultivar IAC-19, submetidas a dois tipos de deslintamento, durante o armazenamento por 18 meses em condicôes de ambiente não



Figura 14. Incidência de Fusarium spp. em sementes 
de algodão nas seis amostras da cultivar IAC-20, submetidas a dois tipos de deslintamento, durante o armazenamento por 18 meses em condicớes de ambiente não

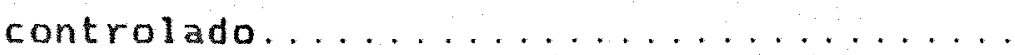

Figura 15. Incidência de Aspergillus spp. en sementes de algodão, nas seis amostras da cultivar IAC-19, submetidas a dois tipos de deslintamento, durante o armazenamento por 18 meses em condicões de ambiente

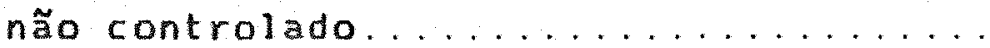

Figura 16. Incidencia de Aspergillus spp. en sementes de algodão, nas seis amostras da cultivar IAC-20, submetidas a dois tipos de deslintamento, durante o armazenamento por 18 meses em condicões de ambiente

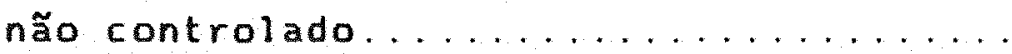

Figura 17. Incidência de fenicillium spp.em sementes de algodão, nas seis amostras da cultivar IAC-19, submetidas a dois tipos de deslintamento, durante o armazeriamento por 18 meses em condicões de ambiente não controlado................

Figura 18. Incidência de fenteillium spp. en sementes de algodão, nas seis amostras da 
Página

cultivar IAC-2O, submetidas a dois tipos de deslintamento, durante o armazenamento por 18 meses em condicóes de ambiente

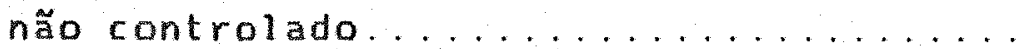




\section{LISTA DE TABELAS}

Página

Tabela 1. Amostras de sementes de algodão empregadas para verificaça do efeito do deslintamento e armazenamento na qualidade fi-

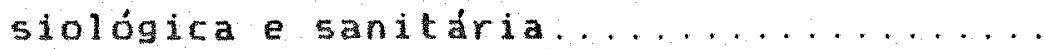

Tabela 2. Umidade das sementes de algodão (Método da Estufa, $24 \mathrm{~h}$ a $105^{\circ} \mathrm{C}$ ) submetidas a dois tipos de deslintamento durante o armazenamento por 18 meses em condicôes de ambiente não controlado. Resultados médios de 12 lotes de sementes de algodão......

Tabela 3. Umidade média de doze amostras de sementes de algodão durante 18 meses de armazenamento sob condicôes de ambiente não

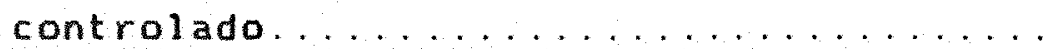

Tabela 4. Germinafão de sementes de algodão (Rolo de Pano, avaliąão após 4 dias de incuba6ão a $30^{\circ} \mathrm{C}$ ), submetidas a dois tipos de deslintamento e armazenadas por 18 meses em condicôes de ambiente não controlado. Resultados são médias de 12 amostras de

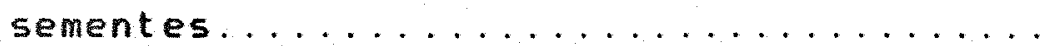

Tabela 5. Germinação média de 12 amostras de sementes de algodão durante 18 meses de armazenamento sob condicões de ambiente não 
Página

controlado...................

Tabela 6. Envelhecimento acelerado das sementes de algodăo (mantidas por 96 horas em câmara a $42^{\circ} \mathrm{C}$, com $100 \%$ de Umidade Relativa, com a realização, em seguida, do teste de germinacão) submetidas a dois tipos de deslintamento durante o armazenamento por 18 meses em condicões de ambiente não

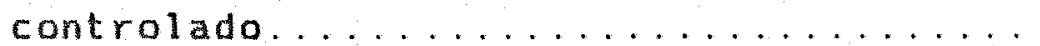

Tabela 7. Resultados médios da aplicacão de envelhecimento acelerado em 12 amostras de sementes de algodão durante 18 meses de armazenamento sob condiçôes de ambiente não controlado.

Tabela $B$. Incidência, durante o armazenamento por 18 meses em condicões de ambiente não controlado, de Colletotrithum gossypil em sementes de algodão (Método do papel de filtro, 7 dias de incubação) submetidas a dois tipos de deslintamento. Resultados são médias de doze amostras de sementes.

Tabela 9. Incidência média de Colletotrichum gossypiz em sementes de algodão durante 18 meses de armazenamento sob condicões

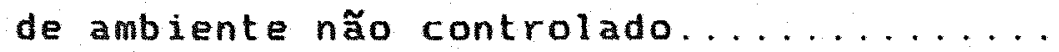


Tabela 10. Incidência, durante o armazenamento por 18 meses em condicốes de ambiente năo controlado, de Fusarium spp. em sementes de algodão (Método do papel de filtro, 7 dias de incubacão) submetidas a dois tipos de deslintamento. Resultados são médias de doze amostras de sementes.......

Tabela 11. Incidência média de Fusarium spp. em sementes de algodão durante 18 meses de armazenamento sob condiç̃es de ambiente não

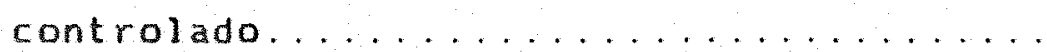

Tabela 12. Incidência, durante o armazenamento por 18 meses em condicôes de ambiente não controlado, de Botryodiplodia sp. em sementes de algodão (Método do papel de filtro, 7 dias de incubacão) submetidas a dois tipos de deslintamento. Resultados são médias de doze amostras de sementes..

Tabela 13. Incidência média de Botryodiflodia sp. em sementes de algodão durante 18 meses de armazenamento sob condicões de ambiente

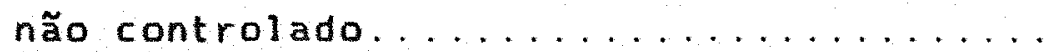

Tabela 14. Incidência de Aspergillus spp., durante o armazenamento por 18 meses em condicões de ambiente não controlado, em sementes 
Página

de algodão (Método do papel de filtro, 7 dias de incubacáo), submetidas a dois tipos de deslintamento. Resultados são médias de doze amostras de sementes......

Tabela 15. Incidência média de Aspergillus spp.em sementes de algodão durante 19 meses de armazenamento sob condicôes de ambiente



Tabela 16. Incidência de Penicillium spp., durante o armazenamento por 18 meses em condicões de ambiente não controlado, em sementes de algodão (Método do papel de filtro, 7 dias de incubacão) submetidas a dois $t i-$ pos de deslintamento. Resultados são médias de doze amostras de sementes.......

Tabela 17. Incidência média de fenteillium spp em sementes de algodão durante 18 meses de armazenamento sob condicões de ambiente

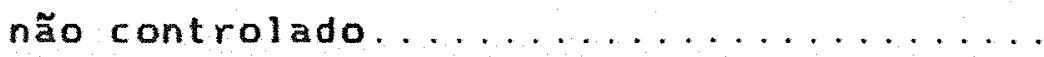

Tabela 18. Matriz de correlação entre as variáveis germinacão, envelhecimento acelerado, umidade, Colletotrichun gossypii, Botrsodiplodia SP. Fusarium SPP., Aspelgillus

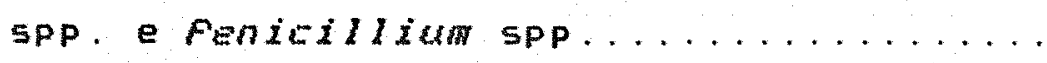




\section{EFEITO DO DESLINTAMENTO A FLAMA SOBRE A QUALIDADE FISIOLÓGICA E SANIDADE DE SEMENTES DE ALGODX̃O}

Autora: Flávia Rodrigues Alves Patricio Orientador: Prof. Dr. José otávio Machado Menten

RESUMO

Este trabalho foi realizado com o objetivo de verificar o efeito do deslintamento através da flambagem, quando comparado ao mecanico, sobre a qualidade fisiológica e sanitária de sementes de algodão, logo após o deslintamento e durante o armazenamento por 18 meses.

Foram avaliadas a umidade, a germinacăo, o vigor (emergência em areia e envelhecimento acelerado) a a sanidade das sementes de algodão submetidas aos deslintamentos por flambagem e mecânico.

Para avaliagão da umidade utilizou-se o método da estufa a $105^{\circ} \mathrm{C}$ por 24 horas. Para a avaliacão da germinacão foram seguidas as Regras para análise de sementes (BRASIL, 1980) e a emergência em areia foi efetuada plantando-se as sementes em bandejas plásticas e contando-se as plântulas normais após 15 dias. 0 outro teste de vigor (envelhecimento acelerado) foi avaliado por intermédio do teste de envelhecimento acelerado, que se 
processou com a colocąẫo das sementes em câmara a $42 \%$ c por 96 horas. A avaliacão da sanidade foi realizada com a utilizacão do método do papel de filtro, com a incubacão das sementes por 7 dias a $20 \% \mathrm{C}$.

Ds resultados mostraram que as sementes flambadas mantiveram teores de umidade constantemente inferiores aos das sementes deslintadas mecanicamente, durante os 18 meses de armazenamento. Como aparente consequiência, a germinaçăo e a emergência em areia das sementes flambadas foram $n$ itidamente superiores às das sementes unicamente deslintadas mecanicamente, durante o periodo de estocagem, acentuando a diferenciacão com o passar do tempo.

Quanto ao vigor, estimado pelo envelhecimento acelerado, considerando todo o periodo do experimento, os dados mostraram que, embora as sementes flambadas tenham apresentado indices superiores aos das deslintadas mecanicamente, a diferenca não foi tão expressiva quanto para a germinafão. Considerou-se que o periodo de manutencăo das sementes na câmara tenha sido prolongado.

Com relação à sanidade, muitos fungos saprófitas ocorreram, mas só foram considerados os fungos com atividade patogênica: Colletotrichum gossyfic, Fusarium SPP. e Botryodiplodia sp. e os fungos de armazenamento Aspergillus SpP. e fenimillikm spp. 
Näo houve diferenca quanto à incidência de $C$. gow as deslintadas mecanicamente. Para Fusarium spp. não houve diferenca logo após o deslintamento, mas o decréscimona viabilidade do fungo durante o armazenamento foi mais acentuado nas sementes flambadas. Aspergillus SpP. e Penicillikn spp. acorreram em maiores niveis em sementes deslintadas mecanicamente, possivelmente devido ao maior teor de umidade que as mesmas possuiam durante todo o periodo de estocagem. Os fungos de campo perderam a viabilidade durante o armazenamento, com decréscimo mais rápido para C. sossypil e mais lento para fusarium spp. Os fungos de armazenamento apresentaram aumento na incidência com o transcorrer do periodo de estocagem.

Não houve correlaçăo entre germinação e emergência em areia, possivelmente devido à interferencia do fungo fhizopus sp. que foi observado, mas não quantificado, prejudicando a germinacão das sementes. Destaca-se que o referido fungo encontra condicốs ideais para se desenvolver no ambiente em que é conduzido o teste de germinação. 
EFFECT OF FLAME DELINTING ON PHYSIOLOGICAL QUALITY, HEALTH, AND STORAGE OF COTTON SEEDS.

Author: Flavia Rodrigues Alves Patricio Adviser: Prof. Dr. José ot ávio Machado Menten

SUMMARY

The objective of this work was to study the effect of flame and mechanical delinting on physiological quality and health of cotton seeds along 18 months storage. Seed moisture content was determined by 1055 of weight after 24 hours in an oven at $105^{\circ} \mathrm{C}$. Percent germination was measured according to the Rules for seed Testing (BRASIL, 1980). The accelerated ageing test was evaluated after maintaining the seeds at $42^{\circ} \mathrm{C}$ for 96 hours. Health assessment was made by the blotter test, after incubating the seeds for 7 days at $200 \mathrm{C}$.

The results obtained showed that the flame delinted seeds kept a smaller degree of moisture content than the mechanically-delinted seeds along the 18 -month period of storage. As a consequence, germination and emergence in sand of the flame-treated seeds were significantly higher throughout the experiment period, and the difference increased with time. 
In the average of the 18-month interval, data of accelerated-aged seeds showed higher germination for flame delinted seeds as compared with the mecanicallydelinted ones, although the differences were not as marked as for the conventional germination test. It was concluded that the duration of the ageing treatment in the chamber was too long.

Health evaluation revealed the presence of many saprophytic fungi but only those with pathogenic activity Collecotirthum gossspit, fusariam spp., Botrgotiflodia sp.) and the storage fungi (Agpelgillus spp. and Pentillidur spp.) were measured.

There was no difference of occurrence of $C$. gossypit and Botryodiplodia sp. between flame or mechanically-delinted seeds. The same thing was observed for Fusalium spp. soon after the delinting, but later the reduction in the viability of this fungus was more pronounced in the flame-treated seeds. Aspelgillas spp. and Pentillitum SPP. occurred at a higher degree in mechanically-delinted seeds, probably due to the higher moisture content of this treatment along all the storage period. Field fungi lost viability during storage; the decline of viability was faster for $C$. gosgyfi $i$ and slower for Fusalium spp. On the other hand, the incidence of storage fungi increased as the storage time advanced. There was no correlation between germination and emergency in 
$x \times \dot{I}$

sand, possibly due to the interference of fhizopus 5 P., whose presence was observed, but not quantified, reducing seed germination. Ideal conditions for the development of this fungus are the same ones in which the germination test is performed. 


\section{INTRODUC:ั0}

o algodão é cultivado em 17 Estados do Brasil, alcancando em São Paulo um dos mais elevados niveis tecnológicos. As sementes utilizadas para plantio neste Estado são selecionadas pelo Instituto Agronômico de Campinas e produzidas e distribuidas em regime de exclusividade pelo Departamento de Sementes Mudas e Matrizes, da Coordenadoria de Assistência Técnica Integral, da Secretaria de Agricultura e Abastecimento.

A semente de algodão é naturalmente revestida pelo linter, uma fibra curta que a envolve e dificulta o tratamento quimico e o plantio com semeadeira. Além disso, - linter impede a passagem pela mesa gravitacional, operacão que tende a melhorar a qualidade das mesmas.

Atualmente as sementes de algodão, no Estado de São Paulo, sofrem o deslintamento mecânico, nos Servicos de Producão de Sementes da Secretaria da Agricultura. A Cooperativa central de Campinas realiza deslintamento adicional com ácido sulfúrico em sementes adquiridas por seus cooperados.

Embora o deslintamento quimico adicional das sementes, retirando totalmente o linter, permita seu 
processamento e facilite as operacóes de tratamento e plantio, para a Secretaria da Agricultura, o mesmo é praticamente inviável. Isto devido ao volume elevado de sementes a serem processadas em um curto espaco de tempo e à necessidade de vultosos investimentos. Como a quantidade de sementes produzidas é elevada (aproximadamente 400.000 sacos de $30 \mathrm{~kg}$ por anol, muito superior ao volume processado pela Cooperativa, haveriam riscos para o meio ambiente.

Como uma alternativa para melhorar a qualidade da semente produzida pela secretaria, esta em implantacão um projeto para realizar a flambagem das sementes. 0 processo realizado após o deslintamento mecânico, consiste na passagem das sementes por uma chama que consome parte do linter remanescente. Este deslintamento adicional tem o objetivo de facilitar o manejo do lote nas operacóes posteriores de beneficiamento, tratamento quimico e semeadura.

$$
\text { Periodicamente ocorrem safras com condicões }
$$
climáticas adversas, com chuvas no periodo da colheita, afetando negativamente a qualidade das sementes e obrigando a Secretaria da Agricultura a manter estoques reguladores que serão armazenados de um ano para outro. É preciso, portanto, conhecer o comportamento das sementes após a flambagem e verificar se é possivel e vantajoso o armazenamento de sementes flambadas. 
Poucos trabalhos foram feitos a respeito da presenca de patógenos em sementes, como colletotrichum gossgrii, fusariam spp. e Botrgadiflodia sp, após a flambagem e durante o armazenamento. Paralelamente ocorre, neste periodo, o desenvolvimento de fungos de armazenamento, como Aspergillus spp. e feniaillium spp. que podem provocar deterioracóes, decrescendo a qualidade de sementes.

o objetivo deste trabalho foi o de verificar o efeito do deslintamento adicional a flama sobre a germinacão, vigor e sanidade de sementes de algodão em comparação ao deslintamento mecânico, imediatamente após o processo e durante o armazenamento por 18 meses. 


\section{REUISZOO DE LITERATURA}

2.2. Caracteristicas da semente de algodão

A qualidade de sementes de algodão para plantio é baixa, quando comparada à de cereais como milho, trigo e até de soja. A qualidade é influenciada por diversos fatores, antes, durante após a colheita (DELOUCHE, 1981).

A deterioracão de sementes inclui todos os decréscimos na qualidade, desde a fecundacão até a germinacão (HALLOIN, 1986), tendo portanto, início no campo. Sementes deterioradas produzem estandes esparsos, ocasionando, muitas das vezes o replantio. plantulas oriundas de sementes deterioradas podem apresentar cotilédones necróticos, raizes anormais e aumento na suscetibilidade a patógenos. As plântulas apresentam, também, decréscimo no vigor e atraso na maturacão (WATKINS, 1981). A deterioracão de sementes de algodão se processa no campo, durante o armazenamento ou após o plantio. Independentemente da causa, para haver deterioracăo há necessidade de elevada umidade e condicóos que favoreçam 0 desenvolvimento de microrganismos, particularmente fungos (WATKINS, 1981 ). 
No campo, o periodo entre a fecundacão e a maturidade, onde as condicões climáticas influenciam decisivamente a qualidade de sementes de algodão, dura entre 65 e 75 dias (NOGLE, 1973).

Devido ao extenso periodo de florescimento, a formacão dos capulhos está sujeita a una série de condicães ambientais estressantes (NDGLE, 1973). A colheita parcelada permite diferenciar lotes de acordo com a idade dos capulhos. Os capulhos formados na parte intermediária da copa da planta parecem fornecer as melhores sementes, pois para os capulhos formados muito cedo há menor quantidade de produtos fotossintetizados, por causa da competicăo com outros capulhos sendo formados ao mesmo tempo. A localizacão baixa na planta sujeita-os à excesso de umidade, baixa aeração e temperaturas elevadas. A semente formada em capulhos mais tardios perde em qualidade por causa do crescimento restrito, sendo as sementes menores, mais leves e com maior proporcão óleo:proteina (LEFFLER, 1981). Devido a estes fatores, os lotes, de idades diversas, frequentemente produzem sementes diferenciadas, com velocidades de germinacão distintas (NOGLE, 1973).

\section{2.e. Tipos de desilintamento}

A semente do algodoeiro, é revestida por fibras longas e pelo linter, composto por densas fibras curtas 
dispostas em volta da semente e que a isolam de seu envoltório, diminuindo a absorcão de àgua e atrasando a germinaço. Abaixo do tegumento há um endosperma fino e o embrião que possui uma radicula e cotilédones mostrando glândulas de gossipol (GELMOND, 1979).

Desta forma o deslintamento é essencial para aumentar a absorcão de água, aumentar a fluidez da massa de sementes e facilitar a emergência no campo. o processo pode ser mecânico ou químico (GELMOND, 1979), sendo o primeiro Processo o mais utilizado mundialmente (SILVA, 1977).

o deslintamento mecânico é realizado com várias serras ajustadas próximas à semente, realizando movimento rotativo. Ocasionalmente é necessário que a operacão se repita mais de uma vez. Durante o deslintamento, podem ocorrer danos nas sementes que proporcionam pontos de entrada aos microrganismos (GELMOND, 1979). As sementes danificadas no deslintamento mostram cortes ou rachaduras profundas. Quanto maior a umidade das sementes no momento do deslintamento, maior a probabilidade de ocorrerem danos mecânicos (DELOUCHE, 1981). 0 dano provoca a morte da semente e anormalidades nas plântulas. 0s cotilédones, muitas vezes, são danificados, podendo apodrecer dentro do tegumento (GELMOND, 1979). Quanto mais intensos forem os danos mecânicos, menor deverá ser a germinaçăo e a capacidade de armazenamento das sementes (DELDUCHE, 1981). - deslintamento mecânico acentua a distincăo entre os 
componentes do lote mas não o suficiente para permitir o processamento, que separa sementes imaturas, com baixa densidade. As sementes deslintadas mecanicamente aumentam a eficiência de semeadura, muito embora ainda mantenham parte do linter aderido ao seu tegumento. As limitacóes do deslintamento mecânico, levaram ao desenvolvimento de outros métodos de deslintamento complementares que possibilitam a retirada mais efetiva do linter (DELDUCHE, 1981). No Brasil grande parte da semente de algodoeiro utilizada é deslintada mecanicamente, sem passar por processos complementares (SILUA, 1977).

No deslintamento químico, realizado após o mecânico, o linter é desintegrado por ácidos (GELMOND, 1979). Há basicamente três sistemas de deslintamento com ácido: via úmida concentrada, via limida diluida e via gasosa o primeiro e o último processos, produzem sementes totalmente livres de linter, e a via limida diluida produz sementes total ou parcialmente liures de linter.

Na via úmida concentrada o deslintamento é realizado com ácido sulfúrico concentrado. 0 equipamento utilizado é simples. As sementes recebem o tratamento com ácido sulfúrico em uma câmara e, após o deslintamento, são lavadas, para retirada do linter degradado, e secas. Ocorrem problemas na qualidade das sementes se a reaça for demorada, a temperatura elevada ou, segundo DELOUCHE(1981), quando houver mais de $12 \%$ de danos mecânicos. 05 principais 
inconvenientes do processo são o alto custo do ácido sulfuirico e o destino dos residuos que são jogados em rios (DELOUCHE, 1981).

No sistema da via úmida diluida é utilizada uma solução com $10 \%$ de ácido sulfúrico. As sementes recebem tratamento com a solucăo, são secas e, assim, ficam com a solucão ácida aderida à sua superficie. o linter degradado é removido por serras, através do uso de forcas friccionais em um tambor rotativo. A neutralizacão do ácido residual é realizada com amônia. A quantidade de ácido consumida é menor que a empregada na via úmida concentrada e o linter hidrolizado pode ser utilizado na preparafão de etanol ou como alimento animal. Problemas na qualidade de sementes parecem estar associados a calor durante a secagem (DELDUCHE, 1981).

- deslintamento pela via gasosa é realizado em regiones semi-áridas dos EUA, pois a umidade das sementes precisa estar abaixo de $9 \%$. As sementes são secas até $\mathbf{5}-\mathbf{7 \%}$. inseridas em uma câmara rotativa, com aquecimento a $60-$ $700 \mathrm{C}$, onde é injetado gás de ácido cloridrico anidro. Após esta operação o linter degradado é retirado por frição e a neutralizaço da acidez, presente nas sementes, realizada com amônia. o equipamento utilizado é sofisticado e Problemas no controle do deslintamento resultam em reducões na germinacão e no vigor (DELOUCHE, 1981). 
As sementes deslintadas com ácido são mais suscetiveis às condicões adversas no momento do plantio, pois são mais sensiveis a baixas temperaturas e excesso de umidade no solo (GELMDND, 1979).

No deslintamento através da flambagem, também realizado após o deslintamento mecânico, as sementes de algodoeiro passam, por gravidade, através de um tubo vertical que possui um bico queimador de gás na sua parte inferior, cujas chamas flambam grande parte do linter. Existem várias versões do método e relatos de temperaturas no interior do tubo de até $1315^{\circ} \mathrm{C}$ (SILVA, 1977). A aparelhagem utilizada é simples, além de possibilitar uma operacão mais econômica em relacão aos outros métodos de deslintamento complementares (SILUA, 1977). A fluidez da massa aumenta, facilitando o plantio, mas não o suficiente para permitir processamento adequado. Após a flambagem é crucial que ocorra rápido resfriamento, para que não haja queima das sementes (DELDUCHE, 1981).

2.3. Efeito do desintamento sobre a qualidade fisiológica das sementes de algodão

\subsubsection{Germinaço e emergênc1a}

Comparando diferentes métodos de deslintamento, sementes que receberam deslintamento complementar a flama 
parecem se situar numa classe qualitativamente intermediária entre a das sementes deslintadas apenas mecanicamente, e a das sementes deslintadas com ácido sulfürico (FERRAZ et alii, 1977; MAEDA et alii, 1977; oTAZú, 1986). Por outro lado, SANTIAGO (1978), estudando a germinacão, e OTAZú (1986), avaliando a emergência em campo, não encontraram diferenca significativa no desempenho das sementes deslintadas por três métodos (flambagem, ácido sulfúrico e apenas mecânico). HELMER (1965), citado por DELOUCHE (1981), fez uma detalhada comparação entre o comportamento em laboratório e no campo de sementes deslintadas mecanicamente, deslintadas a flama e com ácido sulfúrico. A semente deslintada com ácido sulfúrico absorveu umidade, germinou e emergiu mais rapidamente que sementes deslintadas a flama que, por sua vez, foram superiores, quanto ao desempenho, às sementes deslintadas mecanicamente. Em testes envolvendo dois tipos de solo, temperaturas ótimas e sub-ótimas, e vários potenciais hidricos, as sementes deslintadas com ácido se comportaram melhor que sementes deslintadas a flama ou apenas mecanicamente (HELMER, 1965, citado por DELOUCHE, 1981).

1. HELMER, J.D. Field and laboratory performance of cottonseed processed by different methods. Mississippi, M.S., 1965. (Ph. D. - Mississippi State University). 


\title{
2.3.2. Envelhecimento acelerado
}

\begin{abstract}
Uma das maneiras de fazer a diferenciacão qualitativa de lotes é através da submissão das sementes a condicóes de estresse. Há diversos testes de vigor como o de frio, o de velocidade de emergencia, o de crescimento de plântulas, o de tetrazólio o de envelhecimento acelerado (DELOUCHE \& BASKIN, 1970). 0 teste de envelhecimento acelerado pode ajudar a distinguir lotes que resistirão melhor ao armazenamento. Lotes com germinacăo inicial semelhante muitas vezes se comportam de maneira diversa, ao serem submetidos ao armazenamento, provavelmente devido às condicões ambientais adversas por que passam entre o periodo de maturagão e a estocagem. As respostas ao envelhecimento acelerado, também, podem estar associadas ao desempenho dos lotes quanto à emergência, ao crescimento e à produtividade de plantas (DELDUCHE \& BASKIN, 1973).
\end{abstract}

Diversos trabalhos foram realizados utilizando - envelhecimento acelerado em sementes de algodão. A metodologia difere de acordo com os autores, sendo aplicadas condicões de temperaturas de $50^{\circ} \mathrm{C}$ (BOLLENBACKER et alii 1963; WHANJURA et alii 1969), 420 C (SILUA, 1977; BISHNOI \& DELOUCHE, 1980; USBERTI, 1984; LAGO, 1985; OTAZUं, 1986) e 400C (DHARMALINGHAN \& BASU, 1978), periodos de exposicão variáveis de $48,72,84,96,120,144$ horas e $100 \%$ de umidade relativa (BOLLENBACKER et alii, 1963 , 
WANJURA et alii, 1969; SILUA, 1977, DHARMALINGHAN \& BASU, 1978, BISHNOI \& DELOUCHE, 1980; USBERTI, 1984; LAGO, 1985; oTAZu, 1986). Nota-se que sementes de algodão, quando comparadas às de outras espécies, suportam, durante o envelhecimento acelerado, elevadas temperaturas (até $500 \mathrm{C}$ ) e periodos prolongados de exposicão. BOLLENBACKER et alii (1963) observaram considerável reducăo nos indices de vigor somente após exposicão das sementes por 144 horas a $50^{\circ} \mathrm{C}$. Ds autores verificaram que o principal efeito do envelhecimento acelerado foi sobre a velocidade de emergência das sementes, atrasando-a. WANJURA et alii (1969) mostraram que sementes que não sofreram envelhecimento acelerado apresentaram maior germinacão e vigor, e emergência um pouco maior $e$ mais rápida. A produtividade de plantas, oriundas de sementes que sofreram envelhecimento acelerado foi reduzida. BISHNOI \& DELOUCHE (1980), estabelecendo correlacões entre valores de germinacăo e de vigor obtidos em laboratório com a emergência em campo, observaram que as correlaçóes mais altas foram obtidas com os testes de vigor efetuados, entre eles o envelhecimento acelerado. Com o objetivo de identificar diferencas entre lotes submetidos à estocagem, USBERTI (1984) e LAGO (1985), antes de procederem o armazenamento, utilizaram diversos periodos de exposicão das sementes às condicöes do teste de envelhecimento acelerado. Embora tenham encontrado valores elevados de 
correlação entre envelhecimento acelerado e os resultados de germinacão das sementes coletadas nas diversas épocas avaliadas, durante a estocagem, nem sempre este foi o melhor parâmetro para a previsão da qualidade durante o armazenamento.

Alguns trabalhos foram feitos comparando o comportamento de lotes, com diferentes deslintamentos, submetidos ao envelhecimento acelerado. DHARMALINGAM \& BASU (1978) verificaram que sementes com linter residual apresentaram maior germinacão do que as sementes deslintadas com ácido sulfúrico, totalmente desprovidas de linter. SILUA (1977), observou que as sementes flambadas forneceram resultados de vigor (envelhecimento acelerado) semelhantes aos obtidos pelas sementes deslintadas mecanicamente. OTAZú (1986), obteve maiores indices em sementes deslintadas a flama do que com ácido sulfúrico.

\section{4. Métodos de deslintamento e separacăo por densidade das sementes}

Uma das vantagens do deslintamento quimico ou por flambagem é a possibilidade da passagem das sementes, durante o beneficiamento, através da mesa gravitacional. Com este processo, as sementes mais leves e as impurezas săo eliminadas do lote. Foi observado que sementes mais densas possuem maior capacidade de germinafão e vigor 
relatados aumentos na producão de algodão com o plantio de sementes oriundas da fração mais pesada da mesa gravitacional (CHESTER, 1940; JOHNSON et alii, 1973; HOFMANN et alii, 1988). Para várias cultivares, a densidade parece ser um bom indicador da maturidade das sementes no momento da colheita (BARTEE \& KRIEG, 1974). Sementes com menor densidade apresentam maior lixiviaça de acúcares, Ca e K. sendo a densidade diretamente relacionada a taxa de emergência, emergência total e sobrevivência de plântulas (KRIEG \& BARTEE, 1975). Maior incidência de microrganismos patogênicos na cultura de algodão foi encontrada em sementes menos densas (BAIN, 1934; PIZZINATTO et alii, 1983b; PIZZINATTO, 1988) com exceGão do fungo Colletotrythum gossypii, que foi encontrado em maiores quantidades nas sementes mais densas por PIZZINATTO (1988).

\subsection{Efeito do deslintamento sobre o armazenamento de sementes de algodão}

- armazenamento de sementes de algodão engloba três fases distintas. A primeira compreende desde a colheita até a separacão da fibra das sementes; é uma fase critica, pois os capulhos podem ser colhidos sob condifões climáticas variáveis e o periodo de armazenamento ser prolongado. A segunda fase ocorre após a separacão da fibra, quando as sementes permanecem armazenadas até que 
fibra, quando as sementes permanecem armazenadas até que sejam deslintadas e embaladas. Na terceira fase, as sementes preparadas permanecem armazenadas até o plantio, por periodos prolongados (DELOUCHE, 1981).

A longevidade de sementes é afetada por diversos fatores, entre estes, conteúdo de umidade, temperatura, aeração (oxigênio), potencial genético, umidade relativa e sanidade. É também estabelecido que o estado fisiológico (grau de deterioracăo) da semente exerce um importante papel na resposta à deterioracão. Se as condicões de temperatura/umidade forem favoráveis, microrganismos também alteram drasticamente a qualidade de sementes armazenadas. As sementes perdem a habilidade de germinar em virtude de diversos fatores. Pode haver esgotamento ou mobilizacão das reservas, com alteraçóes quimicas nas mesmas, fazendo com que percam a utilidade como fonte de energia. Os lipidios sofrem oxidacão, havendo aumento na quantidade de ácidos graxos livres. As proteinas passam por mudancas, com decréscimo na solubilidade, degradação parcial e diminuicão na digestibilidade. Muitos outros compostos sofrem alteracões qualitativas e quantitativas durante o armazenamento. Ocorrem, também, perda da integridade das membranas, alteracões na atividade enzimática e cromossômica, talvez como consequência de uma quebra nos mecanismos naturais de reparacão das células (ROSS, 1986) 
Durante o armazenamento, o teor de água tem grande efeito sobre a qualidade das sementes. Quanto menor a umidade, maior o período em que o material pode ficar estocado. Fibras a sementes com 8-10\% de umidade podem ser armazenadas por até 30 dias, com 10-12\% por 20 dias, com 12-14\% por 10 dias e com 14-15\% por 3 dias (BASKIN, 1981). outro fator importante é a presenca de materiais estranhos ao lote, tais como restos de caules, folhas e outras partes da planta, normalmente com teores mais elevados de água, que se misturam à fibra e sementes, aumentando o teor de água e diminuindo o periodo de estocagem segura do lote (WILKES, 1978; BASKIN, 1981).

Antes do deslintamento, pode haver considerável redução na qualidade das sementes se a umidade for elevada e não houver aeração da massa. As companhias produtoras de sementes do Delta do Mississipii (EUA) não estocam, destinando à extração de óleo, sementes com mais de $10-12 \%$ de àgua (DELDUCHE, 1981; BASKIN, 1981).

As sementes de algodão de boa qualidade apresentam boa armazenabilidade quando comparadas às de outras sementes oleaginosas (DELOUCHE, 1981). A manutencão da longevidade por periodos mais prolongados também é dependente da umidade e temperatura em que as sementes são mantidas. Os recipientes que impedem a troca de ar e umidade com a atmosfera geralmente aumentam a longevidade de sementes. Comparando-se sementes mantidas em sacos com 
sementes em recipientes herméticos, verificou-se que os ult imos proporcionaram 2 anos a mais de longevidade para as sementes, desde que os niveis de umidade das mesmas estivessem abaiko de 11\% (SIMPSON, 1935; BOCKHOLT et alii, 1969). Estes resultados se devem à variagão na umidade de sementes, que entram em equilibrio higroscópico com o ar. SIMPSON \& WILSON (1944) estabeleceram uma curva comparando a umidade relativa (UR) da atmosfera com a umidade das sementes. Até $65 \%$ de UR a relacão é linear; quando a UR do ambiente for $10 \%$ a umidade das sementes é de $3,5 \%$, quando for $65 \%$ a umidade das sementes é de $9,5 \%$ e quando a UR do ar estiver acima de $70 \%$ a umidade das sementes estará acima de 10\%, valor critico para que o processo da deterioracão se acentue.

Destacando a importância da umidade do ambiente na conservacão das sementes, foi observado por SIMPSON (1946) que sementes armazenadas em diversas regiões Produtoras dos EUA mant inham diferentemente a viabilidade. A vitalidade das sementes foi prolongada na medida em que a região de conservacão se tornava mais seca. Assim, enquanto nas regióes áridas a vitalidade foi mantida por até 14 anos, nas regiôes úmidas não ultrapassou os 3 anos.

$$
\text { Em sementes armazenadas por periodos }
$$

prolongados, quanto maior a umidade e temperatura, menor o periodo de sobrevivencia das sementes, chegando a ser de apenas alguns meses, quando ambas forem elevadas (SIMPSON, 
1935; SIMPSON, 1957; PATE \& DUNCAN, 1964). SOb temperaturas baixas $\left(0,5^{\mathrm{m}} \mathrm{C}\right)$, e teores de umidade de até $11 \%$, sementes de algodão estocadas mantiveram a germinação por até 37 anos (STEWART \& DUNCAN, 1976). As companhias produtoras de sementes nos EUA estocam, em condicões de ambiente não controlado, por até dois anos (DELOUCHE, 1981).

No Estado de São Paulo, vários autores estudaram o armazenamento de sementes. RODRIGUES FILHO et alii (1979) e CIA et alii (1980) observaram decréscimo na germinação de sementes armazenadas em condicões de ambiente não controlado por até 24 meses, tendo este efeito se manifestado a partir dos 6 e 16 meses respectivamente. Já USBERTI (1984) e LAGO (1985), trabalhando cada um com 20 lotes de sementes de algodão mantidas em condicões de ambiente não controlado, observaram decréscimo na germinacão após 12 meses de armazenamento; Para USBERTI (1984), entretanto, após 5 anos de armazenamento, as sementes ainda se encontravam viáveis. OTAZú (1986) não observou decréscimo na germinacão de dois lotes de sementes armazenados por 12 meses.

Com relação ao armazenamento de sementes deslintadas, SIMPSON (1946) observaram que sementes deslintadas com acido sulfúrico concentrado perderam a viabilidade mais rapidamente do que as não deslintadas, provavelmente porque aquelas absorveram maior quantidade de água da atmosfera, Já MAEDA et alii (1977) e RODRIGUES 
FILHD et alii (1979) constataram que sementes deslintadas com ácido sulfúrico concentrado mantiveram a germinacão por até 12 meses, enquanto sementes deslintadas mecanicamente $e$ flambadas apresentaram decréscimo na germinacão a partir de seis meses de estocagem. Dois lotes testados por OTAZú (1986) não mostraram diferenca significativa entre os tipos de deslintamento após o armazenamento.

A previsão do comportamento dos lotes durante o armazenamento tem sido tentada através de diversos Parâmetros. USBERTI (1984) verificou que, para cada período de armazenamento, com análise a cada 2 meses, por até 50 meses, a germinaç̃o inicial poderia prever o comportamento dos lotes durante o armazenamento, já que os valores de $r$ obtidos foram relativamente elevados durante quase todo o Periodo, não havendo necessidade de realizacão de testes adicionais. LAGD (1985) observou que o melhor parâmetro para prever o armazenamento de sementes de algodão em ambiente foi a germinacão a $20^{\circ} \mathrm{C}$, embora tenha obtido coeficientes de correlacão elevados entre a germinacão inicial e os resultados de germinacăo de sementes armazenadas por até 18 meses. 
2.6. Microrganismos associados às sementes de algodão

Foram realizados, no Brasil, alguns trabalhos de levantamento de microrganismos presentes em sementes de algodão na Paraíba (LIMA et alii, 1982), em Minas Gerais (TANAKA et alii, 1984), em São Paulo (PIZZINATTo et alii, 1984) e no Paraná (BUENO, 1986).

Dentre as 48 espécies de fungos detectados no Brasil, apresentam patogenicidade comprovada: Fusarium oxysporum f.SP. . vasinfectum, Fusarium spp., Botryotiflodia theobromae, Colletotrichum gossyrit, Alternaria SP., Verticillium dahliae, fhizoctonia solani, fiacrophomina phaseolina, fythium spp. e Chagtomium SPP. (GERALDI, 1981; PIZZINATTO, 1988; SOAVE, 1985). Foi demonstrado que microrganismos dos gêneros Aspergillus e ntizopus podem prejudicar o armazenamento, deteriorando as sementes (LIMA et alii, 1984).

2.6.1. Colletotrithum gossspil

o microrganismo Colletotrithum gossymi var cephalosporioides é agente causal da ramulose, doenca caracterizada por superbrotamento e encarquilhamento de plantas de algodão (KIMATI, 1980). Foi observado que, embora a transmissão do patógeno de plantas doentes para as sementes seja relativamente baixa, a transmissão de 
sementes portadoras do patógeno para plantas pode ser elevada, ressaltando a importância de sementes contaminadas e/ou infectadas na introducão do microrganismo em novas áreas (LIMA et alii, 1985, TANAKA et alii, 1990).

c. gossypit provoca tombamento em plantulas (ARNDT, 1944; BALMER et alii, 1966; KIMATI, 1980) e podridão de macãs (McCARTER et alii, 1970; KIMATI, 1980). Niveis mais elevados de $C$. gossypix em sementes estão relacionados à ocorrência de chuvas no periodo que antecede a colheita (ARNDT, 1956; SIMPSON et alii, 1973). BUENO (1986) verificou que houve correlafão negativa entre a incidencia de $C$. gossypit em sementes de algodão $e$ a germinacão e BALMER et alii (1966) observaram que quanto maior o inóculo nas plântulas, maior a incidência de tombamento.

\subsubsection{Fusarium SPP.}

Diversas espécies de Fusarium podem ser detectadas em sementes de algodão. 0 fungo $F$. oxysporum $f$. vasinfectum é agente causal da murcha de fusarium, a mais importante doenfa do algodoeiro no Brasil (CIA, 1977). A semente contaminada ou infectada pode introduzir o patógeno em áreas isentas, infestando-as (KIMATI, 1980). Fungos do gênero Fusalium foram relatados como sendo agentes causais 
de tombamento em plantinhas de algodão (AVERNA SACCÁ, 1920, citado por CIA, 1977). Várias especies foram detectadas em sementes e plantulas com sintomas de tombamento, como $F$. moniliforme, F.seirfi, F. seirfi var acuminatum, $F$. equiseti (RAY \& MCLAUGHLIN, 1941). Foi observado, também, que as espécies F. solani, F. oxssforum e F. Equiseti foram patogênicas às plântulas de algodão, causando morte e podridão de raizes. A maior parte dos isolados provocou necrose de raizes e hipocótilo, sendo que poucos isolados acarretaram tombamento (COLYER, 1988). PIZZINATTO (1988) demonstrou que, en casa de vegetacão, não havia diferenca apreciável entre a patogenicidade de isolados das espécies $F$. equiseti, $F$. monilifome, $F$. semitectum, F. fusarioides, F. sambutinum, F. oxysporume F. Mylarioides, sendo os três primeiros muito frequentes em sementes de algodão. Estes fungos foram considerados Patógenos fracos, ocasionando sintomas de necrose no colo das plântulas. Fusarium spp. são microrganismos frequentemente detectados em macãs coletadas antes da colheita no campo (SIMPSON et alii, 1973), mas a incidencia em niveis elevados de fungos deste gênero em sementes está relacionada à maior precipitacão, no periodo entre a abertura das mafãs e a colheita (ARNDT, 1956).

1 AVERNA-SACCÁ, R. Moléstias cryptogámicas do algodoeiro no Estado de São Paulo. Secr. Agr. Com. e Obras Públicas Est. São Paulo. Sevico de Publicąão. 92 P. 1920. 
Fungos do gênero Fusariuan provocam podridão de mąãs, muitas vezes associados a um complexo de microrganismos. Em $30 \%$ de maçãs coletadas com podridão, foram detectadas diversas espécies de Fusalium (BAGGA, 1968) e, as espécies $F$. Moseum, $F$. moniliforme e $F$. solani. foram frequentemente isoladas por MCCARTER et alii (1970). Estes autores verificaram que, provavelmente, a entrada do microrganismo em macãs ocorria através das brácteas. PIZZINATTO \& MENTEN (1990) determinaram que espécies de Fusarium foram patogênicas às maçãs, na seguinte ordem decrescente de importância: F. oxysporum, F. monilifrorme, F. Fusarioides, F. equiseti, F. semitectum, F. rylarioides e F sambucinum. As macãs com apodrecimento produziram sementes portadoras do fungo.

Alguns autores têm demonstrado que a presenca de Fusarium afeta a germinafão de sementes de algodão. RONCADORI et alii (1971) e PIZZINATTO \& MENTEN (1990) observaram decréscimo na germinacão de sementes com niveis elevados de Fusarium spp. Resultados semelhantes foram encontrados por BUENO (1986) com F. MUniliforme.

\subsubsection{Botryodiflouta 5p.}

o fungo Botryoulflodia sp. pode causar morte de plântulas de algodoeiro, embora em plântulas em idade mais avancada não aparegam sintomas de infeção, apesar da 
existência de colonizacão dos tecidos pelo patógeno (PIZZINATTO et alii, 1983a). o mesmo microrganismo causa podridão de maçãs (PIZZINATTo et alii, 1983a) e pode, através desta colonizacão, passar para as sementes e ser disseminado no campo (PIZZINATto et alii, 1983a).

\subsubsection{Akizupus sp.}

Fhizopus sp. tem sido citado como fungo que acarreta decréscimo na germinaça em laboratório. Ftrizopus niglicans foi isolado de muitas sementes e plântulas apodrecidas no teste de germinacão (TOOLE, 1924; HALLOIN, 1975); sendo que a contaminação de sementes ocorre no campo (GELMOND, 1979). LIMA et alii (1984) demonstraram que Rhizopus SP. Provocou decréscimo na germinatão de sementes após a inoculacão e, em outro trabalho, LIMA et alii (1982) verificaram, no teste de germinacão, a presenca de podridões no hipocótilo e nos cotilédones provocadas por este microrganismo. Deve-se ressaltar que a patogenicidade deste fungo sobre plântulas de algodão tem sido relatada em condicôes de laboratório, não tendo sido encontrados relatos de prejuizo à emergência ou de outra moléstia provocada por Rhizopus sp. em campo. 
2.7. Efeito do deslintamento sobre a incidencia de fungos em sementes de algodá

Só foi encontrado um trabalho sobre o efeito do deslintamento sobre a sanidade de sementes de algodão. BAIN (1934) tratou sementes de algodão com ácido sulfúrico concentrado por 15, 30,45 e 60 minutos e observou que mesmo nas sementes tratadas por 60 minutos foram detectados fungos como Fusarium spP., embora em menor incidência do que nas sementes tratadas por 15 minutos.

2.8. Comportamento de patógenos de sementes de algodão durante o armazenamento

\subsubsection{Patógenos de campo}

C. gogsplil foi encontrado em sementes armazenadas a $1^{\circ} \mathrm{C}$ por até 13,5 anos; após 5 anos de armazenamento o fungo havia perdido a viabilidade apenas em sementes armazenadas com umidade acima de $14 \%$ (ARNDT, 1953). A $8 \%$ de umidade e a $0,5^{\circ} \mathrm{C}, C$. gossyfi $i$ se manteve nos mesmos niveis do inicio do experimento (ARNDT, 1946). Em outro estudo, com sementes armazenadas sob esta mesma temperatura por 2,5 anos, foi verificado tombamento provocado por $L$. gossypit no campo (SIMPSON, 1944). Sob temperaturas mais elevadas o periodo de sobrevivencia do 
fungo se reduz. LUWIG (1924) verificou que em sementes mantidas em condicões de ambiente não controlado de laboratório, $\vec{c}$ gosgypit perdia a viabilidade acentuadamente em um ano. ARNDT (1946) observou que, em sementes armazenadas a diferentes temperaturas $133,21^{\circ} \mathrm{C}$ e temperatura de ambiente não controlado), com teores de umidade variáveis entre 8 e $16 \%$, a sobrevivência do fungo foi nula após 17 meses. Na maior parte dos tratamentos, a germinaç̃o foi pouco alterada durante o armazenamento, com excecão das sementes mantidas com umidade ou sob temperatura elevadas. LIMA et alii (1988) verificaram decréscimo gradativo na viabilidade de $C$. gossypi $i$ var cephalosporioides, em sementes com incidência inicial de $5 \%$ deste patógeno, que não mais sobrevivia nas sementes após 14 meses de armazenamento sob condicóes de ambiente, com temperatura variando de 16 a $33^{\circ} \mathrm{C}$. A germinacão destas sementes foi, após este periodo, de $31,5 \%$. Nota-se, portanto, uma tendência de ambos os fungos perderem a viabilidade antes da perda de germinafăo das sementes.

RONCADORI et alii(1971) observaram que, em sementes armazenadas por 5 meses a $15^{\circ} \mathrm{C}, 15 \%$ do total de fungos presentes, principalmente fusariun spp. e, en menor quantidade, Diplodia gossypina e C. gossspii, perderama viabilidade, e a infeckão do embrião diminuiu em $5,1 \%$.

HALLOIN (1975) verificou que sementes com $20 \%$ de umidade e inoculadas com fhizopus sp. não apresentavam 
alteraçăo na incidência deste fungo durante a incubacão por 21 dias a $35^{\mathrm{c} C} \mathrm{C}$.

2.8.2. Patógenos de armazenamento

Microrganismos também provocam a deteriorafão de sementes durante o armazenamento. Ensre os vários fungos, considerados como de armazenamento, estão espécies de Aspergillus e fenteillium. A maior parte das mesmas é capaz de se desenvolver em tecidos com baixo potencial hidrico. Estes fungos são ativos sob condicões de umidade relativa do ar variáveis entre 65 a $90 \%$. Pode haver contaminacão no campo ou durante o processamento, mas a invasão, em geral, se processa durante o armazenamento (NEERGARD, 1977). Foi demonstrado que, para o algodão, nos EUA, é frequente a contaminacão no campo com Aspergillus niger; a contaminação com Aspergillus flabus ocorre apenas nas regiôes mais áridas, provavelmente porque nas regiões mais úmidas haja competicão com outros microrganismos (SIMPSON et alii, 1973). A umidade e a temperatura são fatores predisponentes para haver deterioracão. Algumas espécies de Aspergillus têm uma temperatura ótima para crescimento elevada, variável de $35^{\circ} \mathrm{C}$ (A. flavus) a $35-40^{\circ} \mathrm{C}$ (A. Candidus). A maior parte dos fungos cresce lentamente a $12-15^{\circ} \mathrm{C} e$, a $50^{\circ} \mathrm{C}$, o desenvolvimento praticamente cessa (NEERGARD, 1977). Os tecidos do embrião não precisam ser 
atingidos para haver a deterioracăo pois, muitos dos microrganismos que infectam as sementes, produzem toxinas, tais como a aflatoxina, que inibem a germinação a sintese de clorofila. Suspeita-se que a lipólise e vários outros processos envolvidos na deterioracăo, sejam resultado da ąão conjunta dos sistemas metabólico das sementes e microbianos (HALLOIN, 1981a).

É, entretanto, dificil separar o efeito microbiano do metabólico na deterioracão de sementes de algodão. ARNDT (1946) observou que apenas em sementes de algodão mantidas com teor de umidade maior do que $14 \%$ e temperatura de $33^{\circ} \mathrm{C}$ poder-se-ia associar a deterioracão ao crescimento de fungos dos gêneros Asfergillus e fendillium. Em sementes mantidas em menores temperaturas e com teores de água baixos, por até 28 meses, não foram observadas relacões entre fungos e deformacões em plântulas ou morte de sementes provocadas pela deterioracão. HALLOIN (1975) verificou que sementes com $20 \%$ de umidade inoculadas com os fungos A. niger e A. flatus, quando incubadas a $35^{\circ} \mathrm{C}$, perderam a viabilidade mais rapidamente do que sementes não inoculadas, embora as últimas também tenham perdido a viabilidade. A incidencia de A. flawus e A. niger nas sementes aumentou durante a incubacão e após 21 dias atingiu praticamente $100 \%$ das sementes e dos embriốes. Os danos nas sementes foram observados antes da invasão dos embriōes, indicando que foram provocados por toxinas 
liberadas por estes fungos. Comparando sementes inoculadas e sem inoculaçăo com $A$. nigzr, submetidas ao envelhecimento acelerado, HALLDIN (1981b) verificou que apenas nas sementes inoculadas houve a liberacão de ácidos graxos, embora a deterioracão tenha se processado em ambos os casos. LIMA et alii (1984), observaram que sementes inoculadas com A. niger e A. flasus perdiam a viabilidade mais rapidamente do que sementes sem inoculacăo, embora estas últimas também tentam sofrido deterioracăo durante o armazenamento por 98 dias. 
3. MATERIAL E MÉTODOS

Neste trabalho foram estudados dois métodos de deslintamento, mecánico e o deslintamento adicional, através da flambagem, empregando 12 lotes de sementes de algodão, sendo seis lotes da cultivar IAC-19 e seis lotes da cultivar IAC-20, os quais foram armazenados por 18 meses em condicões de ambiente não controlado. Avaliou-se, após a retirada de sub-amostras de cada tratamento do armazém, a umidade, a germinação e o vigor cemergência em areia, envelhecimento acelerado) e a sanidade das sementes. As análises foram realizadas no Laboratório Central de Sementes (DSMM/CATI).

\subsection{Amostras de sementes de algodão}

As amostras utilizadas no presente trabalho foram escolhidas em função de informacões recebidas pelo Servico de Producão de Sementes de Ibitinga, DSMM/CATI. Selecionaram-se seis lotes da safra $1986 / 87$ de cada uma das cultivares IAC-19 e IAC-20. Foram escolhidos trés lotes de cada cultivar com germinacão superior a $85 \%$ e três lotes com germinação inferior a $85 \%$. As amostras chegaram ao 
laboratório em setembro de 1987 e foram mantidas em câmara fria e seca $\left(15^{\circ} \mathrm{C}\right.$ e $40 \%$ de umidade relativa) até dezembro, quando foram separadas e sofreram a flambagem. Após o deslintamento a fogo, foram homogeneizadas e separadas, segundo as Regras para análise de sementes (BRASIL, 1980), em sub-amostras representativas dos tratamentos e de suas repeticões. Em janeiro de 1988, as sementes foram reanalizadas para germinacão, segundo as Regras para análise de sementes (BRASIL, 1980), no Laboratório Central de Sementes (Tabela 1 ).

Tabela 1. Amostras de sementes de algodão empregadas para verificaç̃o do efeito do deslintamento na qualidade fisiológica e sanitária

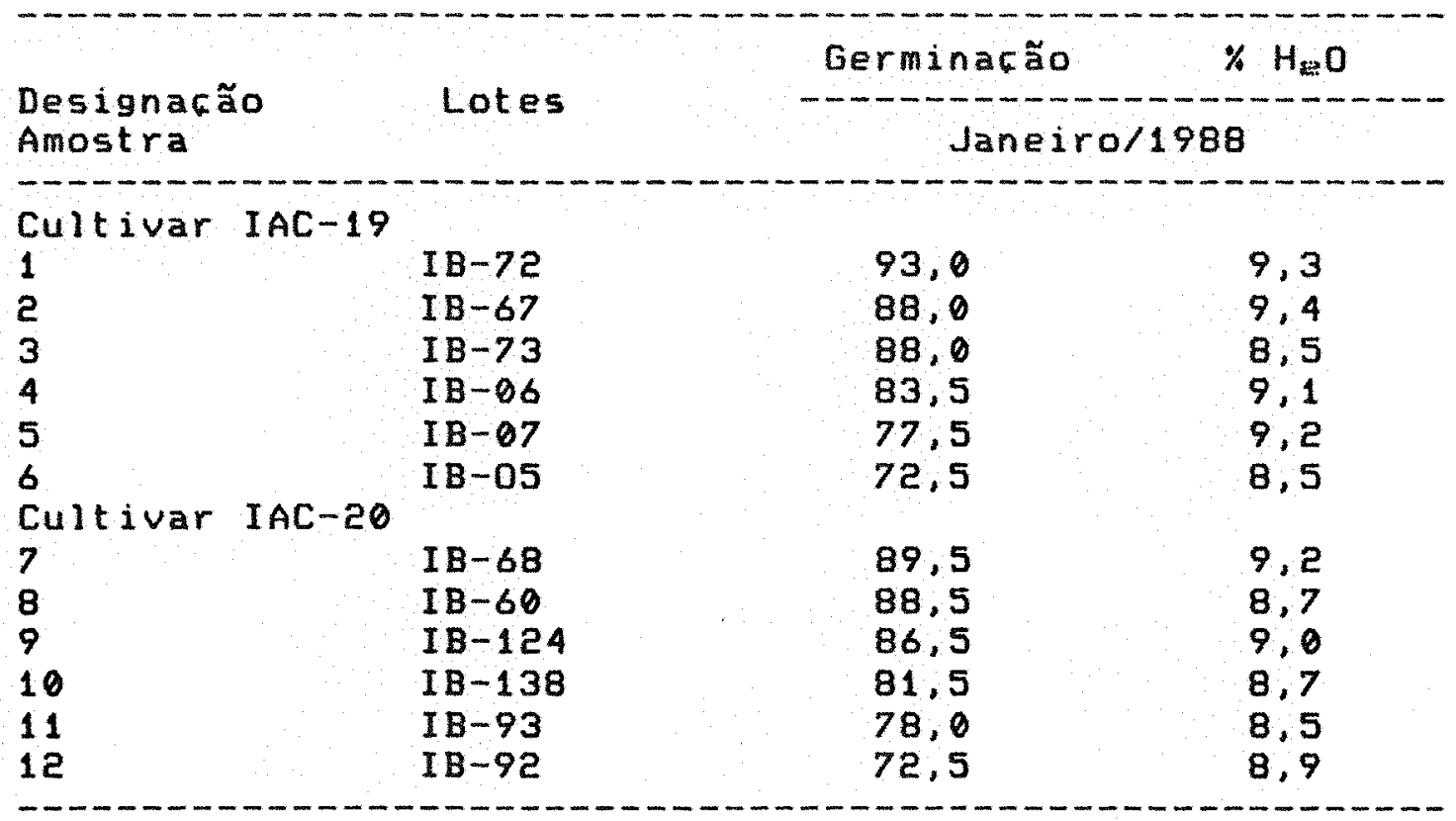




\subsection{Deslintamento}

As amostras foram retiradas de lotes deslintados mecanicamente no servico de producăo de Sementes de Ibitinga. O deslintamento mecânico é feito após a retirada das fibras e uma pré-limpeza das sementes. Estas passam por um sistema de serras que removem com maior intensidade as fibras curtas que revestem as sementes (GELMOND, 1979).

0 deslintamento adicional a flama foi realizado na Seção de Algodão do Instituto Agronômico de Campinas, em um protótipo, desenvolvido por aquela secão. 0 aparelho possui altura total de $324 \mathrm{~cm}$ e é constituido por um tubo assentado sobre um suporte, sob o qual localiza-se a saida para as sementes flambadas. As sementes passam por gravidade através deste tubo, com sessão interna de $8 \times 12 \mathrm{~cm}$ e externa de $20 \times 25 \mathrm{~cm}$, sendo a diferenca preenchida por tijolos refratários. As sementes caem através de uma entrada lateral com altura de $194 \mathrm{~cm} e$ são flambadas durante a queda livre por duas chamas opostas, situadas a $111 \mathrm{~cm}$ das sementes e a $83 \mathrm{~cm}$ do solo. As chamas são formadas a partir de dois misturadores onde há duas entradas de gás e uma de ar comprimido. A regulagem da altura da chama cem funcão da entrada de gás e ar comprimido) é feita através de testes, passando as sementes 
pelo aparelho, até que se atinja o nivel desejado de flambagem das mesmas.

\subsection{Armazenamento das amostras de sementes}

As sementes flambadas e sem flambagem foram acondicionadas em sacos de papel e conservadas no armazém do Servico de Producão de sementes de Campinas, à temperatura ambiente, simulando as condicões em que as sementes são armazenadas pela Secretaria da Agricultura. A estocagem teve inicio em janeiro de 1988. As avaliacóes foram efetuadas a intervalos de três meses, por um periodo de 18 meses: janeiro, abril, julho, e outubro de 1988 e janeiro, abril e julho de 1989, com excecão do teste de emergência em areia que foi realizado nos meses de janeiro de 1988, janeiro de 1989 e julho de 1989.

\subsection{Avaliacóces de qualidade das sementes}

3.4.1. Umidade

Foi determinada segundo as Regras para análise de sementes (BRASIL, 1980). Na primeira avaliacão utilizaram-se duas repeticôes com $50 \mathrm{~g}$ de sementes cada e, nas seguintes, quatro repeticões com 259 de sementes cada. As sementes foram colocadas em estufa a $105^{\circ} \mathrm{C}$ por 24 horas. 
sendo retiradas e pesadas, e o teor de água obtido por diferenca de peso.

\subsubsection{Germinacão e vigor (emergência em areia)}

Efetuou-se o teste de germinacão segundo as Regras para análise de sementes (BRASIL, 1980). As amostras foram semeadas em 4 rolos de pano, com 50 sementes por rolo, previamente esterilizados e umedecidos em água destilada, e colocadas em germinadores a $30^{\circ} \mathrm{C}$. Após 4 a 10 dias, foram contadas como germinadas as sementes que produziram plântulas normais. Cada rolo representou uma repetiธaัo.

Para a avaliação da emergência em areia, utilizaram-se bandejas plásticas contendo areia esterilizada, nas quais foram semeadas 200 sementes por tratamento, sendo 50 sementes por repeticăo. As bandejas foram dispostas de forma inteiramente casualizada no laboratório. Após 15 dias, as plântulas foram retiradas e avaliadas. Foram contadas as plântulas que apresentaram raizes, hipocótilo e cotilédones normais.

\subsubsection{Vigor (envelhecimento acelerado)}

As sementes foram colocadas em estufa com $100 \%$ de umidade relativa e $42^{\circ} \mathrm{C}$ por 96 horas, periodo sugerido 
pelo "Handbook of vigour test methods" (PERRY, 1981). Após este tratamento, as sementes foram submetidas ao teste de germinacão, seguindo os mesmos procedimentos citados no item anterior.

\subsubsection{Sanidade}

As sementes receberam um pré-tratamento com hipoclorito de sodio a $1 \%$ por 3 minutos, sendo que esta desinfestacão superficial mostrou-se mais eficiente para evitar a presenca de Khizopus sp. que prejudica a avaliafão de fungos fitopatogênicos (LIMA et alii, 1982). Colocaramse as sementes em placas de Petri plásticas, com $9 \mathrm{~cm}$ de diâmetro, 10 sementes por placa, sobre três folhas de papel de filtro previamente umedecidas em água destilada e esterilizada. As sementes foram incubadas por 7 dias em câmara com temperatura de $20^{\circ} \mathrm{C}$ sob ciclos alternados com 12 horas de luz ultravioleta e 12 horas de escuro. A detecfão foi realizada com base nos caracteres morfológicos dos fungos observados em microscópio estereoscópico. Foram empregadas 4 repeticões, com 50 sementes cada 15 placas de Petri). 


\subsection{Delineamento análise estatistica}

Para todos os parâmetros avaliados foi empregado 0 delineamento experimental inteiramente casualizado, com quatro repeticŏes. 0 esquema estatistico foi um fatorial 2 (métodos de deslintamento) $\times 7$ (épocas de avaliacão) $x$ 12 (lotes). Cada parcela foi representada por uma sub-amostra com $200 \mathrm{~g}$ de sementes; assim, o experimento contou com um total de 672 recipientes que eram coletados periodicamente para que suas sementes fossem submetidas às análises.

Ds dados em porcentagem foram analisados diretamente, exceto para sanidade, os quais foram transformados em $\sqrt{x+1}$ devido à ocorrência de números com valor zero.

Os dados foram submetidos à análise de variância e, nos casos em que o valor de $F$ era significativo, foi aplicado um teste de média (Tukey, ao nivel de $5 \%$ de probabilidade).

As médias entre as cultivares e as amostras com germinacão inicial acima e abaixo de $85 \%$ foram comparados através do teste $F$ de contraste entre as médias.

Foi feito teste de correlacão entre as variáveis germinaçăo, envelhecimento acelerado, umidade e incidência de C. gossgfit, Fusarium spp. , Botryodiplodia Sp.. Aspergillus spp. e fenitillium spp. 
Esquema estatistico:

\begin{tabular}{lc}
\hline Fontes de variacão & Graus de liberdade \\
\hline Épocas & 6 \\
Deslintamentos & 1 \\
Lotes & 11 \\
Épocas $\times$ Deslintamentos & 6 \\
Épocas $\times$ Lotes & 66 \\
Deslintamentos $\times$ Lotes & 11 \\
Épocas $\times$ Deslintamentos $\times$ Lotes & 66 \\
Residuo & 504 \\
\hline Total & 671 \\
\hline
\end{tabular}


4. REsUltados E DIscusszo:

\subsection{Unidade}

Ds resultados das avaliacóes dos teores de água das sementes, nas várias épocas, estão listados nas Tabelas 2 e 3 .

A umidade das sementes foi variável nas diversas épocas de análise. Os menores valores de umidade das amostras avaliadas foram obtidos na instalacão do experimento, em janeiro de 1988 , seguidos por outubro do mesmo ano. As sementes se encontravam com o maior teor de água em janeiro de 1989.

As sementes flambadas possuiam no inicio do trabalho, teor de água significativamente inferior ao das sementes com deslintamento mecânico e permaneceram, durante todo o periodo de armazenamento, nestas condicões. Era de se esperar que as sementes, ao entrarem em equilibrio higroscópico com a umidade relativa do ar, atingissem o mesmoteor de água após o armazenamento. É provável que a diferenca de umidade detectada entre sementes flambadas e deslintadas mecanicamente se deva a uma certa impermeabilizaçăo do tegumento, provocada pela flambagem, 
ou porque as sementes flambadas, com menor teor de linter, entrem em equilibrio higroscópico com o ar em um nivel mais baixo de umidade.

Esta variaça no teor de água de acordo com a época de avaliacão ocorreu porque as sementes entram em equilibrio higroscópico com o ambiente, como foi demonstrado por SIMPSON \& WILSON (1944). 05 autores calcularam que, possivelmente, o periodo necessário para que as sementes entrem em equilibrio com a atmosfera é de aproximadamente 4 semanas. 0 mês de janeiro de 1989 , quando foram encontrados os maiores teores de água, foi precedido, desde o último decêndio de dezembro, por umidades relativas médias elevadas, como se pode observar na Fig. 1. No mês de outubro de 1988, foram encontrados os menores teores de água, refletindo os baixos indices de umidade relativa do ambiente, indicados pela umidade relativa média, que foi baika desde agosto do mesmo ano.

Na Tabela 3 verifica-se o comportamento das amostras quanto ao teor de água das sementes a nota-se que existe diferenca significativa entre as mesmas, principalmente nas sementes com deslintamento mecânico. As amostras 2 e 3 apresentaram os maiores indices de umidade, e as amostras 7, 9, 10 e 12 os menores valores. Embora tenha havido diferenca entre as amostras, nota-se nas fig. 2 e 3 que, para todas as amostras, com excecão das amostras 
1, 6 e 12, as sementes flambadas permaneceram com umidade inferior à das deslintadas mecanicamente.

As sementes deslintadas mecanicamente das amostras 2, 3, 4, 9 e 10 mostraram aumento mais acentuado, no teor de água no mês de janeiro de 1989, do que as sementes apenas flambadas (Fig. 2 e 3 ).

\subsection{Germinaç̃o e vigor (emergência em areia)}

Ds resultados de germinacão estão apresentados nas Tabelas 4 e 5 .

Houve um decréscimo gradativo na germinacão após o armazenamento. As sementes deslintadas mecanicamente apresentaram uma queda mais acentuada na germinaço do que as deslintadas a flama.

Durante todo o periodo de estocagem as sementes flambadas apresentaram, em média, germinacão significativamente superior à das sementes não flambadas (Tabela 4).

Os resultados médios de germinacão, durante os 18 meses de armazenamento, indicam que as amostras 1, 2, 8 e 9 apresentaram os maiores valores e as amostras 5 e 6 os menores indices de germinacão (Tabela 5). As primeiras amostras apresentaram os maiores valores de germinacão no inicio do experimento. 




$\square$ UR $\quad \cdot$ TEMPERATURA

Figura 1. Dados meteorológicos (Decendiais), coletados na cidade de Campinas, de umidade relativa média e temperatura média, do periodo de janeiro de 1988 a jultho de 1989, fornecidos pela secão de Climatologia do Instituto Agronômico de Campinas. 
Tabela 2. Umidade das sementes de algodão (Método da Estufa, $24 \mathrm{~h}$ a $195^{\circ} \mathrm{C}$ ) submetidas a dois tipos de deslintamento durante o armazenamento por 18 meses em condicões de ambiente não controlado. Resultados médios de 12 lotes de sementes de algodão.




Tabela 3. Umidade média de doze amostras de sementes de algodão durante 18 meses de armazenamento sob condicôes de ambiente não controlado.

\begin{tabular}{|c|c|c|c|c|c|}
\hline \multirow{2}{*}{ Amostras } & \multicolumn{4}{|c|}{ Deslintamentos } & \multirow{2}{*}{ Médias } \\
\hline & \multicolumn{2}{|l|}{ Mecânico } & \multicolumn{2}{|c|}{ Flambagem } & \\
\hline & \multicolumn{5}{|c|}{$-----------------\%---------------1-$} \\
\hline 1 & $10,3 a b c$ & A & $9,8 a b$ & B & $10,1 \mathrm{ab}$ \\
\hline 5 & $10,6 a$ & $A$ & $9,8 a b$ & B & $10,2 a$ \\
\hline 3 & $10,7 a$ & A & $9,9 a b$ & $B$ & $10,3 \mathrm{a}$ \\
\hline 4 & $10,4 a b$ & A & $9,4 \mathrm{ab}$ & B & 9,9 abc \\
\hline 5 & $10,1 \mathrm{abc}$ & A & $9,8 a b$ & B & $10,0 \mathrm{ab}$ \\
\hline 6 & $10,3 a b c$ & A & $9.9 \mathrm{a}$ & B & $10,1 \mathrm{ab}$ \\
\hline 7 & $9,7 \mathrm{c}$ & A & $9, \mathrm{eb}$ & B & $9,5 c$ \\
\hline 8 & $10,2 a b c$ & A & $9,6 \mathrm{ab}$ & B & $9.9 \mathrm{abc}$ \\
\hline 9 & $10,0 \mathrm{abc}$ & A & $9,3 \mathrm{ab}$ & B & $9,7 \mathrm{bc}$ \\
\hline 10 & $10,0 a b c$ & A & $9,3 \mathrm{ab}$ & B & $9,7 \mathrm{bc}$ \\
\hline 11 & $10,5 \mathrm{ab}$ & A & $9,7 \mathrm{ab}$ & B & $10,1 \mathrm{ab}$ \\
\hline 12 & $9,6 b c$ & A & $9,5 a b$ & B & $9,7 \mathrm{bc}$ \\
\hline Médias & $10,3 A$ & & $9,6 \mathrm{~B}$ & & \\
\hline CU\% & $--\cdots$ & & $3,8-$ & $\cdots$ & $\cdots--$ \\
\hline
\end{tabular}

Letras minúsculas comparam médias na vertical e maiúsculas na horizontal.

Médias seguidas pela mesma letra não diferem entre $5 i$ a nivel de $5 \%$ de probabilidade pelo teste de Tukey. 
UMIDADE \%

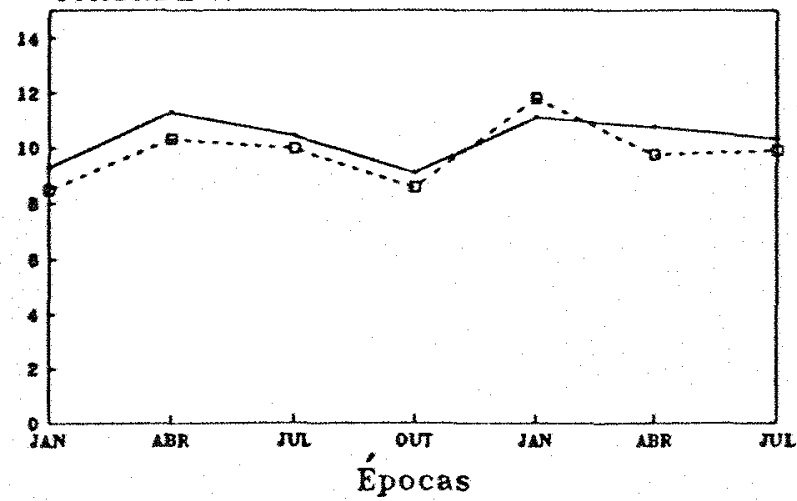

AMOSTRA 3

UMIDADE \%

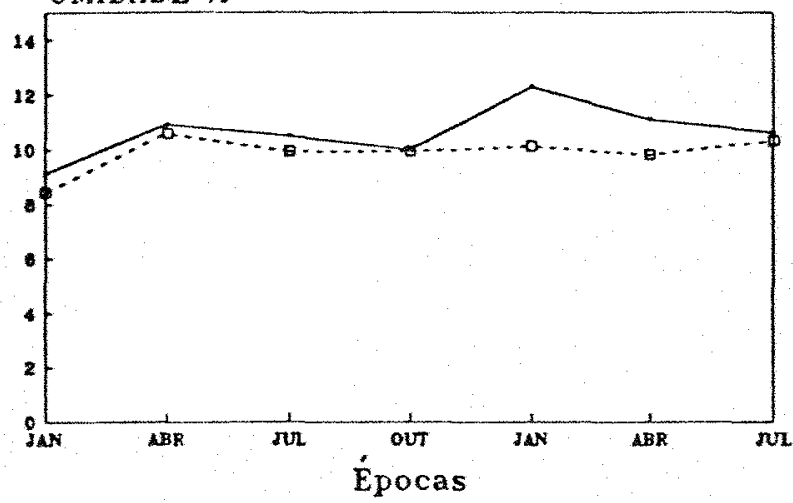

MECÂNICO

AMOSTRA 5

UMIDADE \%

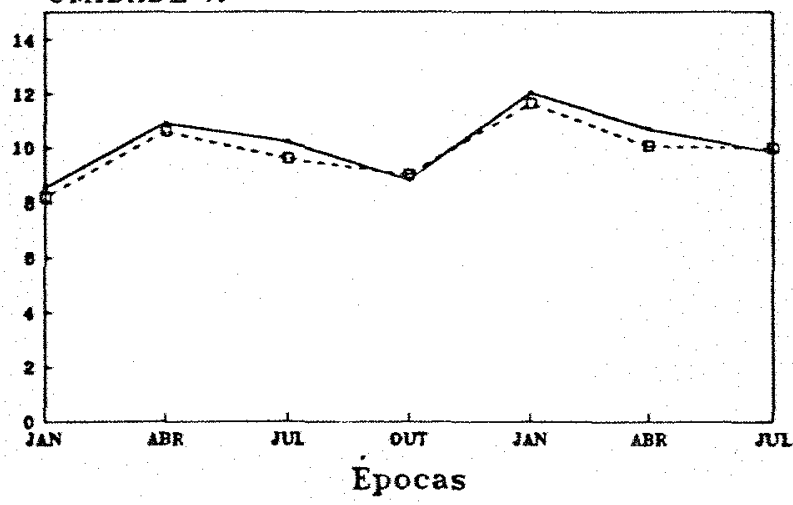

UMIDADE \%

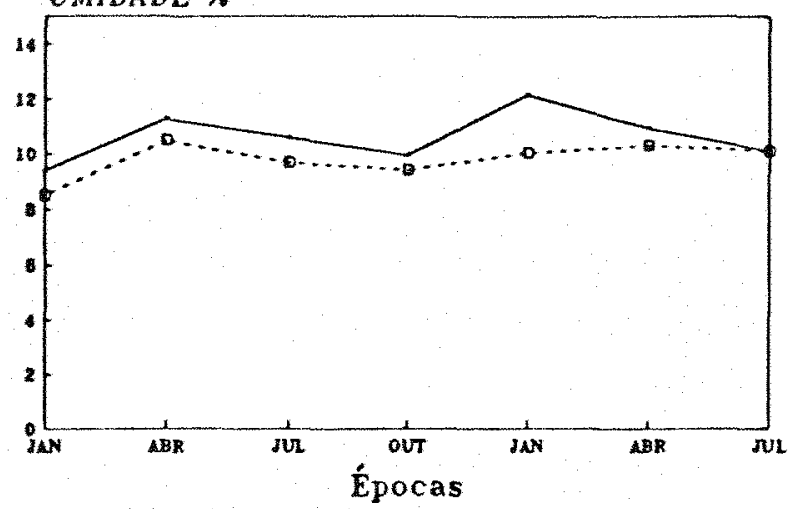

AMOSTRA 4

UMIDADE \%

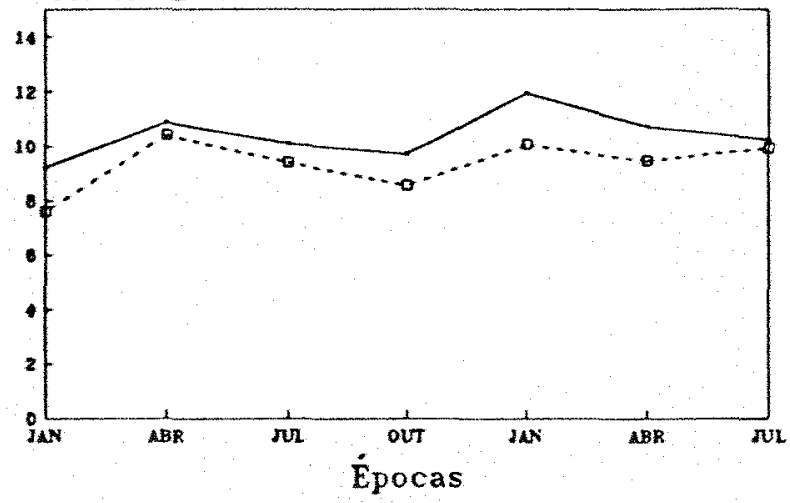

FLAMBAGEM

AMOSTRA 6

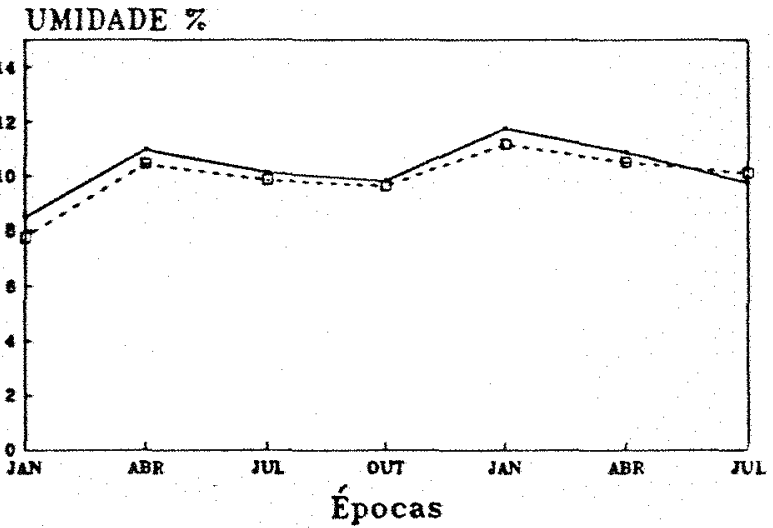

Figura 2. Umidade das sementes de algodão (Método da Estufa, 24h a $\left.105^{\circ} \mathrm{C}\right)$, da cultivar IAC-19, submetidas a dois tipos de desintamento e avaliadas a cada três meses, durante o armazenamento por 18 meses em condicões de ambiente não controlado. 
UMIDADE $\%$

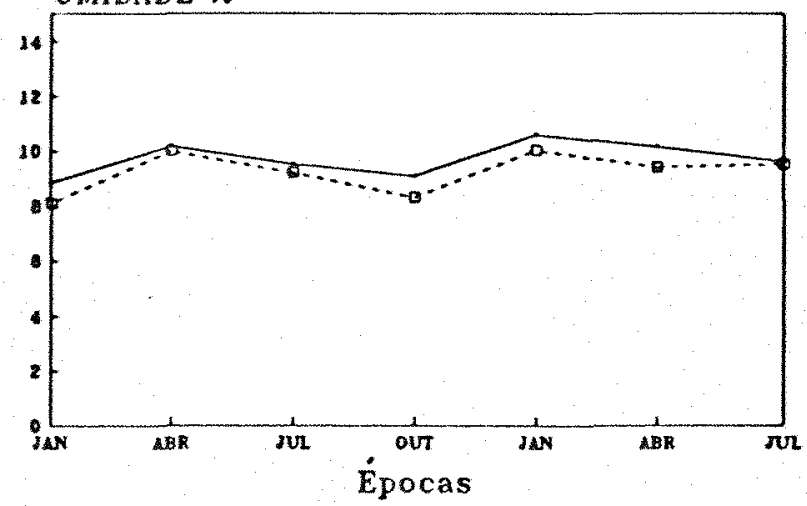

\section{AMOSTRA 9}

UMIDADE \%

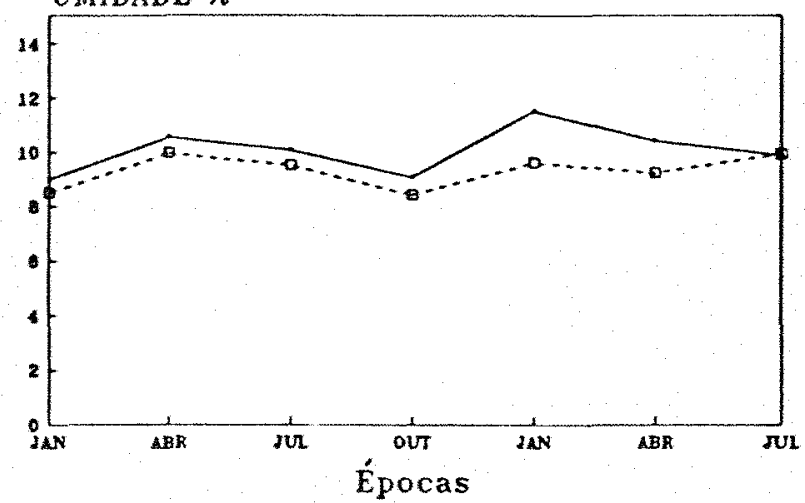

MECÂNICO

AMOSTRA 11

UMIDADE \%



UMIDADE \%



AMOSTRA 10

UMIDADE \%

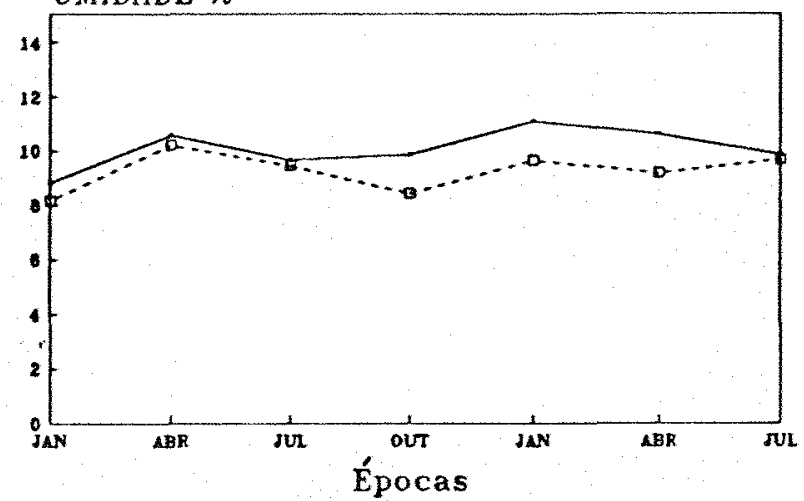

FLAMBAGEM

AMOSTRA 12

UMIDADE \%

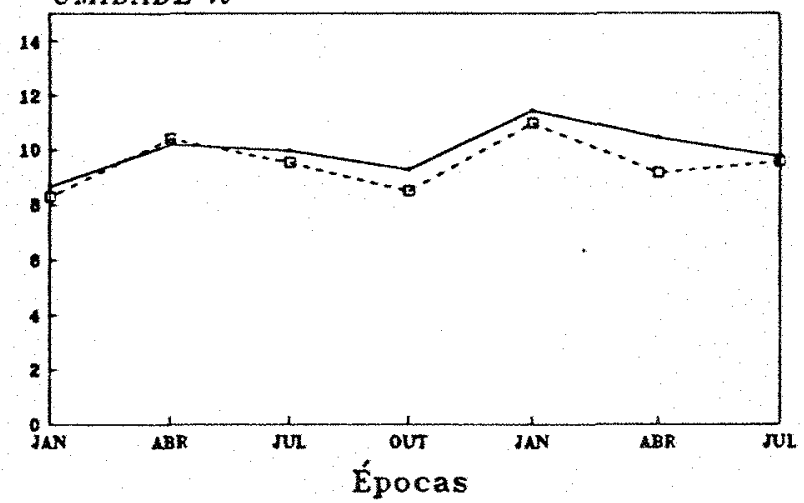

Figura 3. Umidade das sementes de algodão (Método da Estufa, $24 h$ a $105^{\circ} \mathrm{Cl}$, da cultivar IAC-20, submetidas a dois tipos de deslintamento e avaliadas a cada três meses, durante o armazenamento por 18 meses em condicốes de ambiente não controlado. 
Como se pode observar nas fig. 4 e 5 , para todas as amostras durante a estocagem, as sementes flambadas mostraram indices superiores de germinacão, a diferenca se acentuou durante o armazenamento. A amostra 1 (Fig. 4), entretanto, apresentou menor valor de germinacão para sementes flambadas em outubro de 1988 , o mesmo ocorrendo para as amostras 8 e 11 (Fig. 5) em abril de 1989.

A germinafão das amostras da cultivar IAC-19 foi comparada com a das amostras da cultivar IAC-20 através do teste $F$ de contraste entre as médias. Verificou-se que as amostras da cultivar IAC-20 apresentaram germinacão significativamente superior, com a média de $89,2 \%$, à das amostras da cultivar IAC-19, com germinação média de $73,7 \%$ (Fig. 6). Năo houve diferenca entre as cultivares nos primeiros 6 meses de armazenamento ljaneiro de 1988 até julho do mesmo ano). Realizou-se a regressão linear para as médias de ambas as cultivares e foram obtidas as equacões $Y=85,8-1,34 X$ com $r^{E}=-0,97$ para IAC-19 e $Y=86,5-1,08 X$ com $r^{m}=-0,92$ para $I A C-20$, onde $Y$ é a germinaç̃o $e X$ é 0 periodo em meses de armazenagem. observa-se que o coeficiente angular é ligeiramente superior para a cultivar IAC-19, indicando que a inclinacăo da reta é um pouco maior para esta cultivar, confirmando a maior perda de viabilidade para as amostras desta cultivar. 
0 teste F também foi usado para comparar as amostras com indices de germinação iniciais maiores que $85 \%$ com as amostras com germinacão inicial inferior a $85 \%$. Verificou-se que a diferenca se manteve constante durante o armazenamento, como se pode observar na Fis. 7. Realizou-se regressão linear para as amostras com germinacão inicial maior que $85 \%$, cuja equacão é $Y=91,0-1,20 x$, com $r=-0,92$ e menor que $85 \%$, cuja equacão é $Y=81,3-1,22 X$, com $r=0,97$. Verifica-se que os coeficientes angulares das equacões são semelhantes, ou seja as retas têm a mesma inclinação, confirmando a tendência de decréscimo na viabilidade semelhante entre sementes com diferentes qualidades iniciais.

D decréscimo na germinacão foi gradativo, sendo mais acentuado a partir de outubro de 1988, 9 meses após o inicio do experimento. No término do experimento, julto de 1989, perdeu-se $40 \%$ do poder germinativo das sementes deslintadas mecanicamente e $20 \%$ das flambadas. MAEDA et alii (1977), RODRIGUES FILHO et alii (1979), e CIA et alii (1980), observaram inicio no decréscimo da viabilidade a partir de seis meses de armazenamento. Para os primeiros autores, trabalhando com sementes com $55 \%$ de germinaço inicial (GI), após 12 meses de estocagem, as sementes haviam perdido aproximadamente $50 \%$ do poder germinativo; já para RODRIGUES FILHO et alii (1979), trabalhando com sementes semelhantes às anteriores, após 18 meses, as 
sementes haviam perdido $60 \%$ da germinacão inicial. Os dados de USBERTI (1984) mostraram que sementes com (GI) maior e menor que $70 \%$ perderam $17 \%$ da viabilidade, neste mesmo periodo. Dbserva-se nos dados de LAGO (1985), que houve um decréscimo entre $55 \%$ e $58 \%$ na germinacão de sementes com GI maior que $60 \%$, entre 60 e $50 \%$ e GI menor que $50 \%$. Apenas após um periodo mais prolongado de estocagem ( 50 meses) as sementes armazenadas por USBERTI (1984) mostraram diferenca na perda da viabilidade de acordo com sua qualidade inicial. Sementes com GI maior que $70 \%$ perderam $33 \%$ do poder germinativo e sementes com GI menor que $70 \%$ perderam $50 \%$ do poder germinativo. Tanto os dados deste trabalho como os dos demais autores indicam que, para o periodo de armazenamento de até 18 meses, há uma tendência de lotes com diferentes qualidades iniciais apresentarem decréscimo na viabilidade constante. As diferencas quanto à magnitude do decréscimo na viabilidade possivelmente se devam às diferentes origens das sementes utilizadas, grau de deterioracăo das sementes no inicio do armazenamento, condicões climáticas no ambiente em que estas sementes permaneceram estocadas e, aos possiveis teores diversos de umidade destas sementes no inicio do armazenamento. 
Tabela 4. Germinacão de sementes de algodão (Rolo de Pano, avaliacão após 4 dias de incubação a $30^{\circ} \mathrm{C}$ ), submetidas a dois tipos de deslintamento $e$ armazenadas por 18 meses em condicóes de ambiente năo controlado. Resultados são média de 12 lotes.



Letras minúsculas comparam médias na vertical e maiúsculas na horizontal.

Médias seguidas pela mesma letra não diferem entre si ao nivel de $5 \%$ de probabilidade pelo teste de Tukey. 
Tabela 5. Germinação média de 12 amostras de sementes de algodão durante 18 meses de armazenamento sob condicỗes de ambiente não controlado.



Letras minúsculas comparam médias na vertical e maiúsculas na horizontal.

Médias seguidas pela mesma letra não diferem entre si ao nivel de $5 \%$ de probabilidade pelo teste de Tukey. 

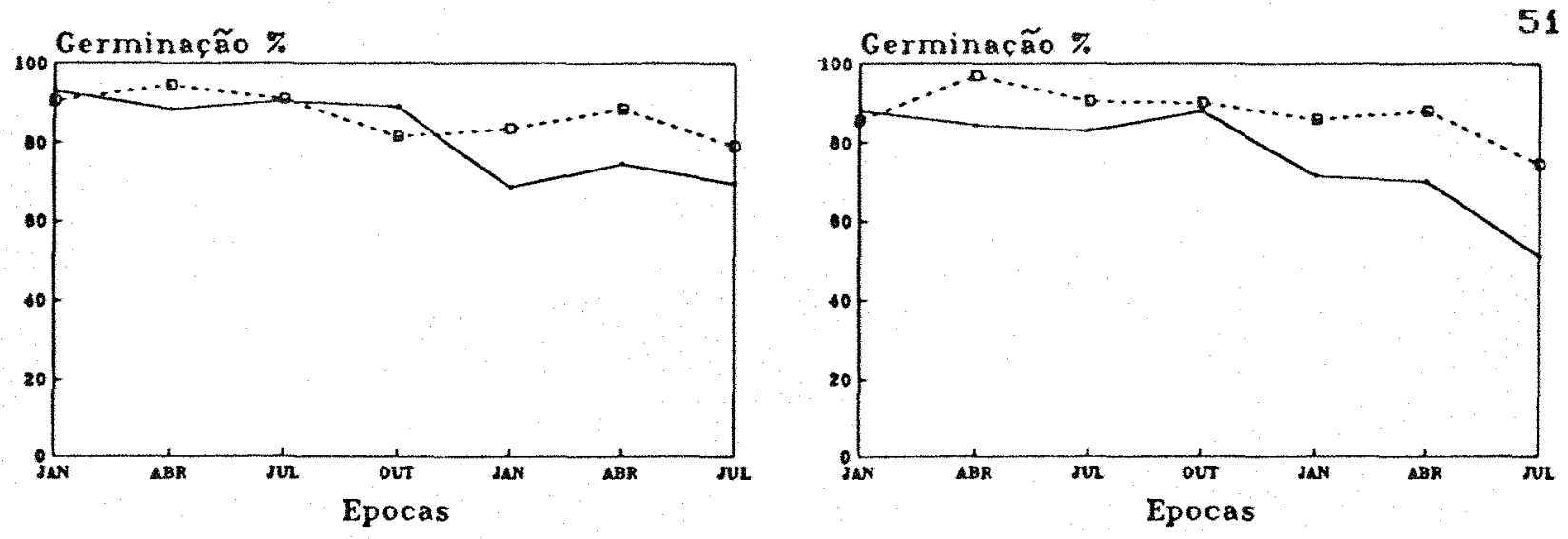

AMOSTRA 3

AMOSTRA 4

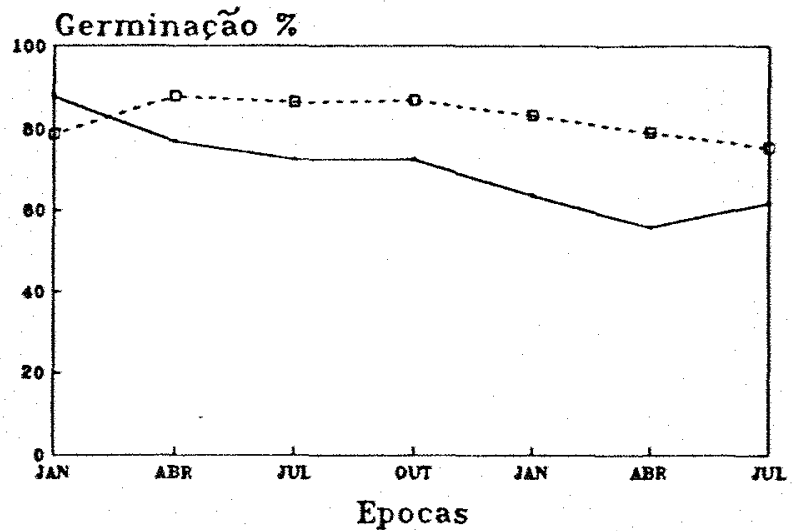

- MECÂNICO

AMOSTRA 5

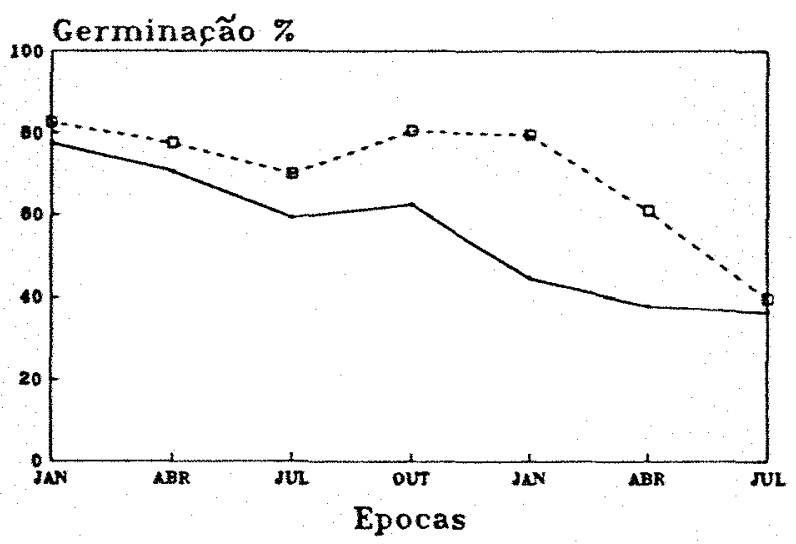



FLAMBAGEM

AMOSTRA 6

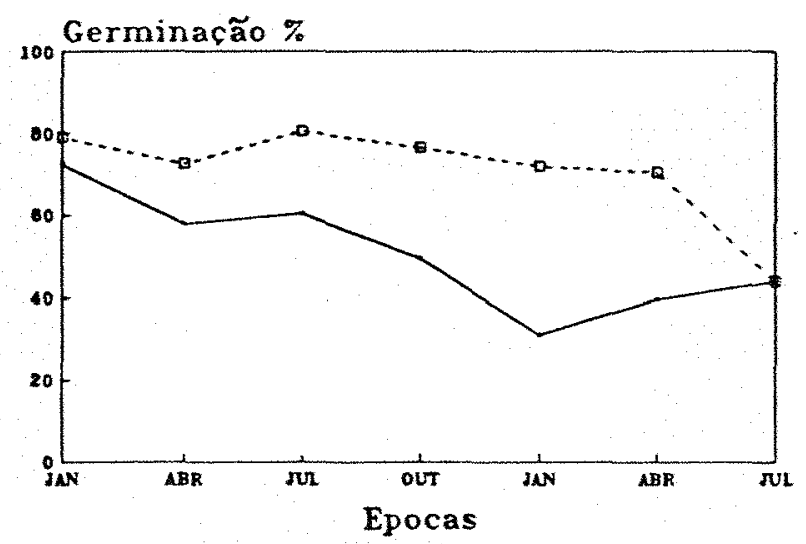

Figura 4. Germinaçăo de sementes de algodão, das seis amostras da cultivar IAC-19, submetidas a dois tipos de deslintamento e armazenadas por 18 meses, com avaliậ̃o a cada três meses. 

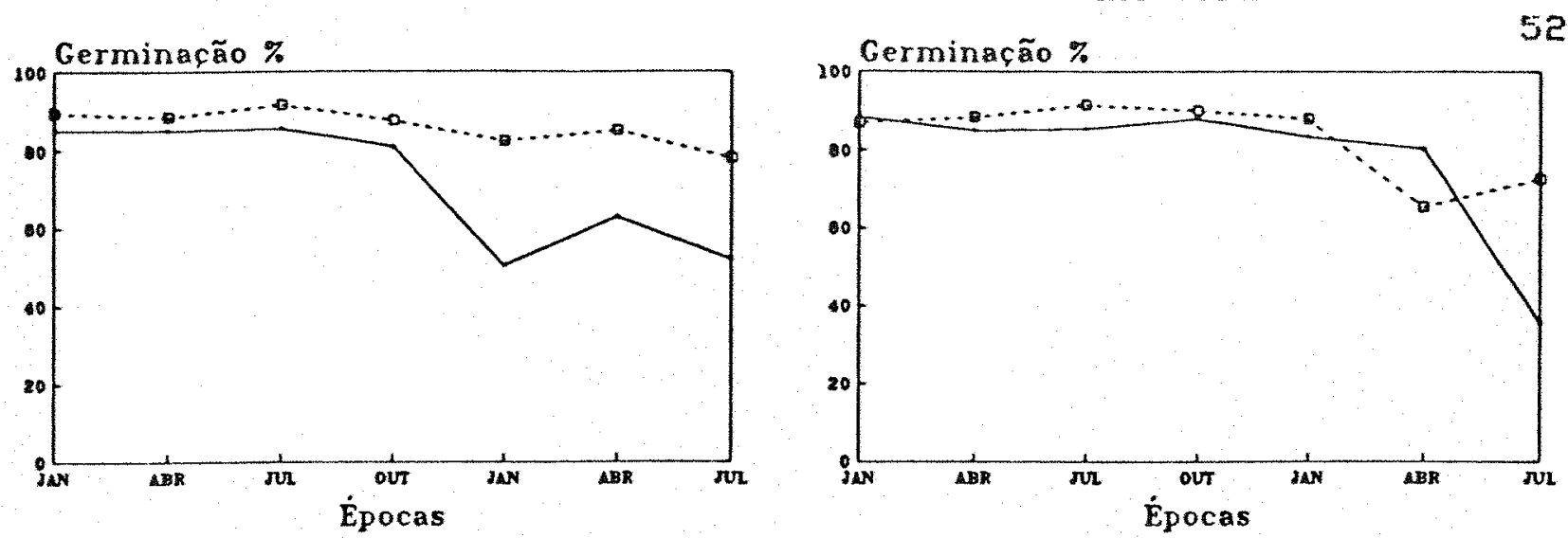

AMOSTRA 9

AMOSTRA 10
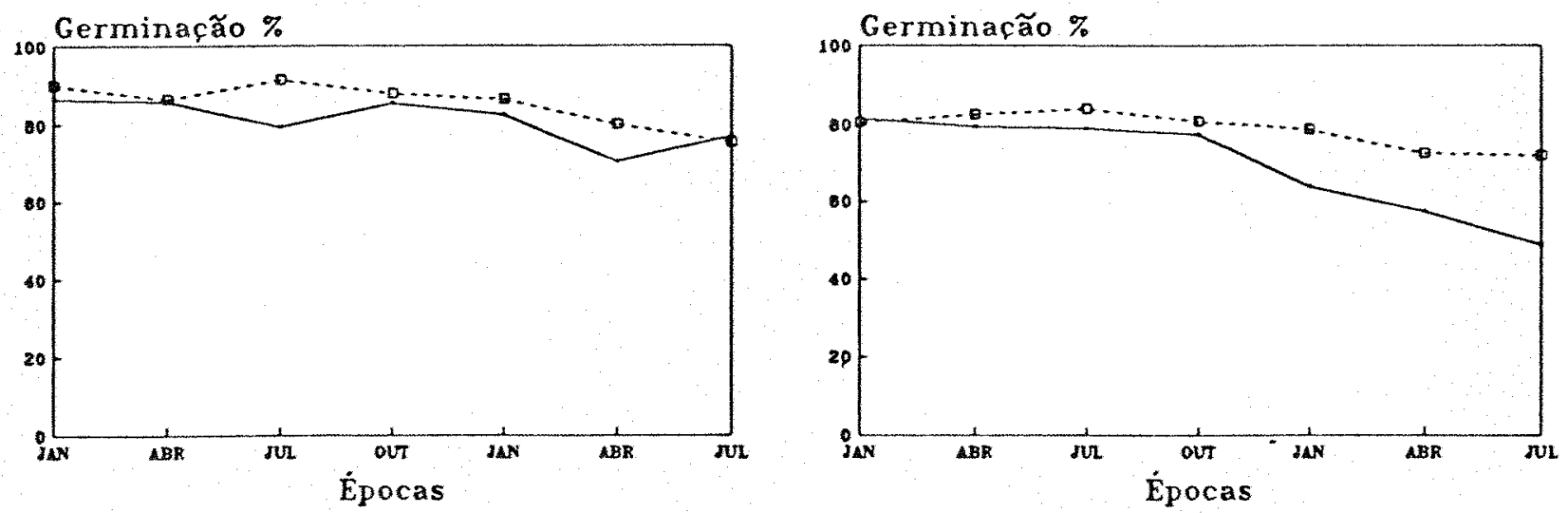

MECÂNICO

FLAMBAGEM

AMOSTRA 11

AMOSTRA 12
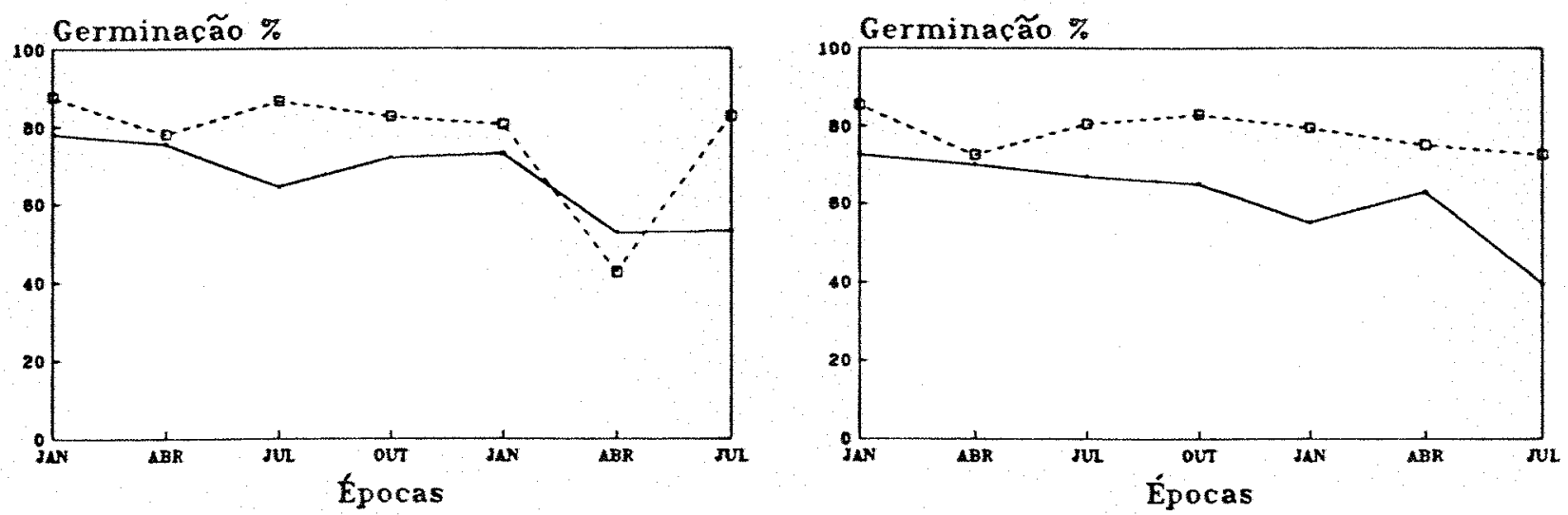

Figura 5. Germinafão de sementes de algodão, das seis amostras da cultivar IAC-20, submetidas a dois tipos de deslintamento e armazenadas por 18 meses, com avaliaça a cada três meses. 


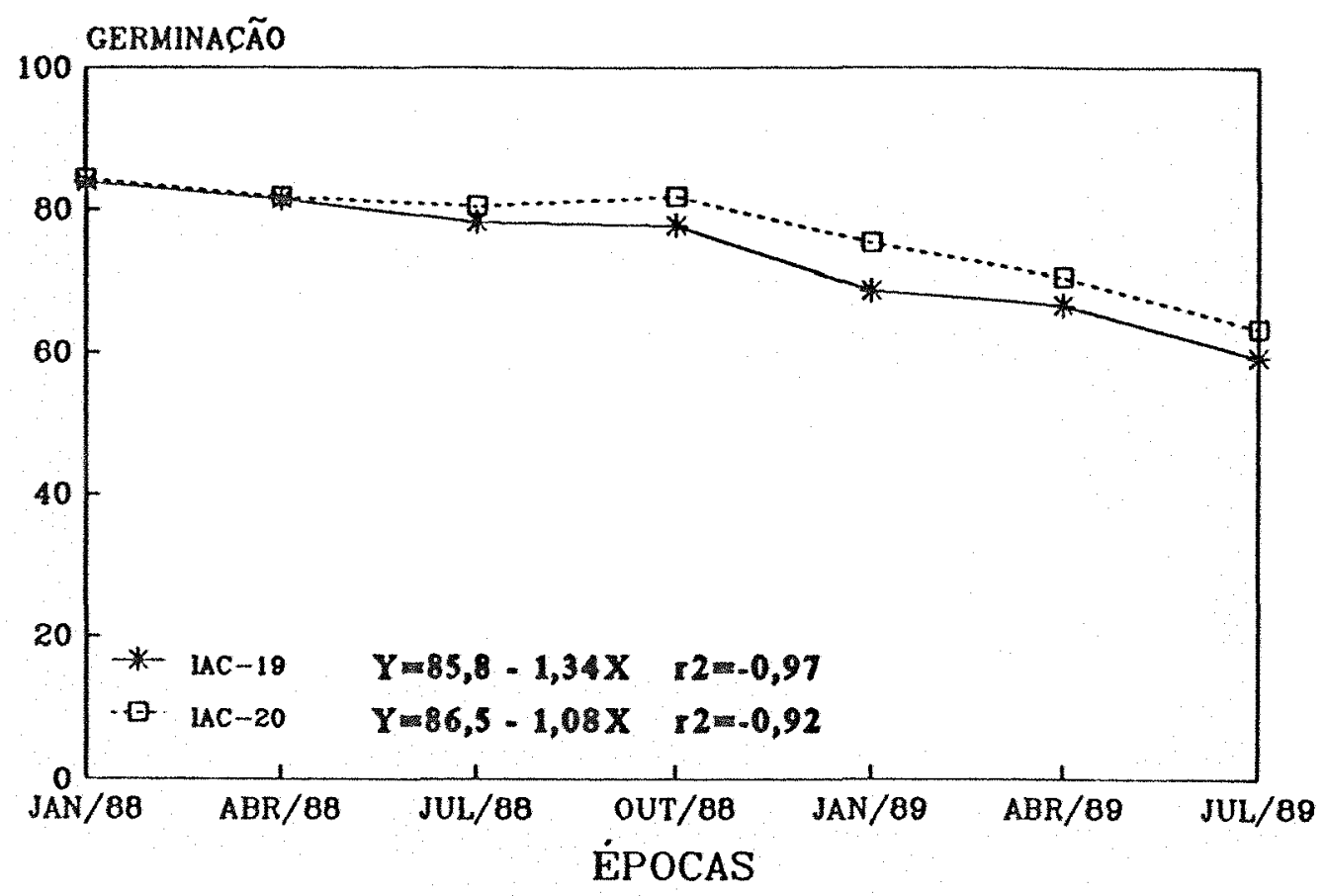

Figura 6. Germinação de sementes de algodão, das cultivares IAC-19 e IAC-20, submetidas a dois tipos de deslintamento, durante o armazenamento por 18 meses em condicóes de ambiente não controlado



Figura 7. Germinacão de sementes de algodão, com germinacão inicial (GI) maior e menor que $85 \%$, submetidas a dois tipos de deslintamento, durante o armazenamento por 18 meses en condicóes de ambiente não controlado 
É de se esperar que no Brasil, com clima tropical, as sementes de algodão tenham uma vida mais curta quando comparadas às sementes mantidas em condicôes de ambiente não controlado nos EUA. Naquele pais, as sementes comerciais são armazenadas por até 2 anos (DELOUCHE, 1981 ).

Foi demonstrado por SIMPSON (1946) que as sementes de algodão apresentam longevidade diferente de acordo com o local em que forem armazenadas. Na regiăo mais árida dos EUA as sementes sobreviveram por até 14 anos e na região mais úmida estavam mortas após 3 anos. No Estado de São Paulo, com grande parte do ano com clima úmido e quente, os trabalhos parecem indicar que um periodo seguro de armazenamento seria até a safra seguinte.

0 deslintamento através da flambagem foi benéfico para a germinacão durante todo o periodo de armazenamento, acentuando-se o efeito deste tratamento após - mês de janeiro de 1989. MAEDA (1977), RODRIGUES FILHO (1979) e OTAZú (1986), não observaram diferenca entre sementes deslintadas mecanicamente e sementes flambadas, quando submetidas ao armazenamento.

As vantagens encontradas para as sementes flambadas, durante a estocagem, talvez se devam ao diferente teor de água das mesmas quando submetidas ao armazenamento, pois as sementes flambadas encontravam-se com teores significativamente inferiores de umidade durante todo o periodo. SIMPSON (1935, 1946) demonstrou que quanto 
mais baiko o teor de água das sementes durante o armazenamento, principalmente para sementes mantidas sob temperatura e umidade constantes, maior o tempo de sobrevivência das mesmas.

- decréscimo na germinatăo durante o armazenamento era esperado, pois ocorre uma série de processos deteriorativos em sementes durante a estocagem (Ross, 1986), inclusive devido à acão de microrganismos. É, entretanto, dificil separar o efeito fisiológico do microbiano (HALLOIN, 1986).

Quanto ao teste de emergência em areia, ilustrado na Fig. 8, observou-se que as sementes flambadas apresentaram resultado de emergência superior ao das deslintadas mecanicamente, assim como ocorreu para germinação. Não foi encontrada correlacão entre a germinacão e a emergência em areia, provavelmente porque no rolo de pano, que é mantido no germinador com temperatura de $30^{\circ} \mathrm{C}$ e umidade elevada, as condicões sejam propicias ao desenvolvimento de Khizopus sp., que provoca podridão de hipocótilo e cotilédones (LIMA et alii, 1982), o que também foi observado, embora não quantificado, neste trabalho. Problemas na germinacăo provocados por este fungo já haviam sido observados por TOOLE (1924), GELMOND (1979), LIMA et alii (1982) e LIMA et alii (1986). fhizopus sp.é um fungo contaminante em laboratório, mas foi descrita a sua penetracão no campo em sementes de algodão (GELMOND, 1979). 
Embora tenham sido utilizados panos esterilizados $e$ os germinadores tenham sido limpos e desinfestados antes de cada experimento, pode ter havido contaminacão através dos rolos de pano e germinadores, já que este é um fungo frequente em laboratório. Em geral, no teste de germinacão, os indices foram ligeiramente superiores aos encontrados no teste de emergencia em areia. Nem sempre as sementes que apresentaram niveis elevados de emergencia em areia mostraram os mesmos resultados no teste de germinacão. Notou-se, no teste de germinacão, que nas sementes flambadas fhizopus SP. ocorria em menor quantidade.

\subsection{Vigor (envelhecimento acelerado)}

Ds dados relativos à aplicacão do teste de vigor (envelhecimento acelerado) nas sementes são mostrados na Tabela 6. Houve variacão no resultado deste nos diversos meses de análise. Os resultados iniciais de envelhecimento acelerado foram os mais elevados sendo que houve uma queda acentuada nestes valores a partir de abril de 1989.

As amostras da cultivar IAC-19 foram comparadas com as amostras da cultivar IAC-20 através do teste $F$ de contraste entre as médias. 


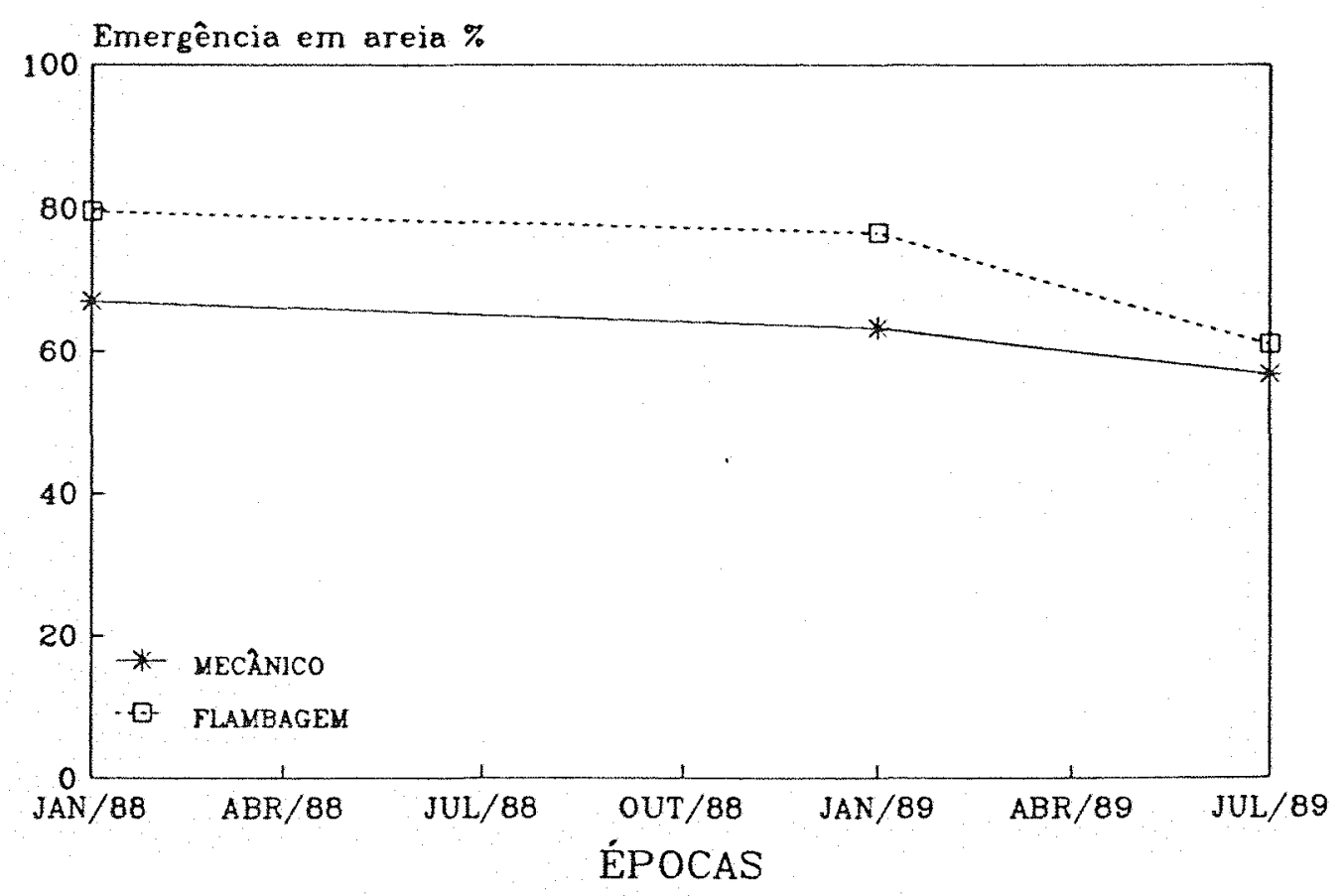

Figura 8. Emergência em areia de sementes de algodăo submetidas a dois tipos de deslintamento e armazenadas por 18 meses, com avaliagão a cada três meses. 
Verificou-se que as amostras da cultivar IAC-20 mostraram valores de envelhecimento acelerado significativamente superiores, com média de $61,4 \%$, aos das amostras da cultivar IAC-19, com média de $56,4 \%$. Năo houve diferenca entre as cultivares nos três ulitimos periodos avaliados (janeiro, abril e julho de 1989).

os resultados de envelhecimento acelerado também podem ter sido influenciados pela quantidade de fungos, como Aspergillus spp. Embora no envelhecimento acelerado as condicões sejam de $100 \%$ de unidade relativa e $42^{\circ} \mathrm{C}$, HALLOIN (1975) observou que, incubando sementes com $20 \%$ de umidade a $35^{\circ} \mathrm{C}$, o fungo Aspergillas flavus aumentava rapidamente e simultaneamente ocorria decréscimo na germinação.

Na Tabela 7 estão listados os valores médios das amostras durante todo o periodo, resultantes da aplicacão do envelhecimento acelerado sobre as sementes. Verifica-se que as amostras 12 e 7 apresentaram os maiores indices de envelhecimento acelerado e as amostras 3 e 11 os menores valores. Para as amostras 4,6 e 9 os indices de envelhecimento acelerado das sementes desintadas mecanicamente foram superiores aos das flambadasi para as amostras 1, 2 e 12 o contrário ocorreu e, para as demais, năo houve diferenca entre os deslintamentos. No entanto, na média das doze amostras, a germinacão após o envelhecimento 
acelerado foi superior nas amostras flambadas (Tabelas b e 7).

De uma maneira geral as sementes flambadas apresentaram maiores valores de vigor, mas não houve consistência nestes resultados, embora, em relação à germinaçăo, a flambagem tenha demonstrado nitida superioridade. Este fato ocorreu provavelmente porque neste teste de envelhecimento acelerado houve flutuacão nos resultados. OTAZú (1986) também não detectou diferenca entre estes dois tratamentos, com relacão ao envelhecimento acelerado.

Verifica-se que as amostras 1 e 2, com deslintamento mecânico, cujo comportamento durante a estocagem está ilustrado na Fig. 9, apresentaram indices de vigor extremamente baixos em julho de 1988 , sendo que o mesmo não ocorreu nas sementes flambadas. As amostras 3 e 5 com deslintamento mecânico e flambagem apresentaram decréscimo no envelhecimento acelerado neste mesmo periodo. Tais fatos podem ser devidos a problemas não detectados na câmara de incubação, pois nos meses subsequentes os mesmos não ocorreram. Verificou-se um decréscimo mais acentuado no envelhecimento acelerado, Para todas as amostras, a partir de janeiro de 1989, após 12 meses de armazenamento.

Embora sementes de algodão tolerem periodos prolongados de exposicão ao envelhecimento acelerado (BOLLENBACKER et alii, 1963; WANJURA et alii, 1969; 
DHARMALINGHAN et alii, 1978; BISHNOI \& DELDUCHE, 1980), acredita-se que o periodo utilizado neste trabalto ( $96 \mathrm{~h}$ ) tenha sido muito elevado, provocando esta flutuacão nos resultados. USBERTI (1984) observou que, realizando envelhecimento acelerado em sementes por este mesmo periodo, após 12 meses de armazenamento, houve morte das sementes. 0 autor considerou o tempo de exposicão muito elevado e concluiu que 84 horas de exposicão seria um período mais adequado.

Dbservou-se, através do teste $F$ de contraste entre as médias, que para sementes armazenadas por 18 meses, os indices de envelhecimento acelerado das amostras com germinacão inicial superior a $85 \%$, com média geral (todo o periodo) de $59,8 \%$, foram significativamente superiores aos indices das amostras com germinacão inicial menor que $85 \%$, cuja média foi $57,3 \%$.

Nem sempre o envelhecimento acelerado é o melhor indicativo para prever o comportamento dos lotes submetidos à estocagem, como foi demonstrado por outros autores ao concluirem que a germinacão inicial (USBERTI, 1984) e a germinacão a $20^{\circ} \mathrm{C}$ (LAGO, 1985), seriam os melhores parâmetros para prever a capacidade de estocagem das sementes. BISHNOI \& DELOUCHE (1980), entretanto, demonstraram que houve maior correlaçăo entre emergência em campo e diversos testes de vigor, do que entre emergência e germinacão. 
Tabela 6. Envelhecimento acelerado das sementes de algodão cmantidas por 96 horas em câmara a $42^{\circ} \mathrm{C}$, com $100 \%$ de Umidade Relativa, com a realizą̆̃a, em seguida, do teste de germinacão) submetidas a dois tipos de deslintamento durante o armazenamento por 18 meses em condicóes de ambiente não controlado.



Letras minúsculas comparam médias na vertical e maísculas na horizontal.

Médias seguidas pela mesma letra não diferem entre si ao nivel de $5 \%$ de probabilidade pelo teste de Tukey. 
Tabela 7. Resultados médios da aplicacão do envelhecimento acelerado em 12 amostras de sementes de algodão durante 18 meses de armazenamento sob condicões de ambiente não controlado.

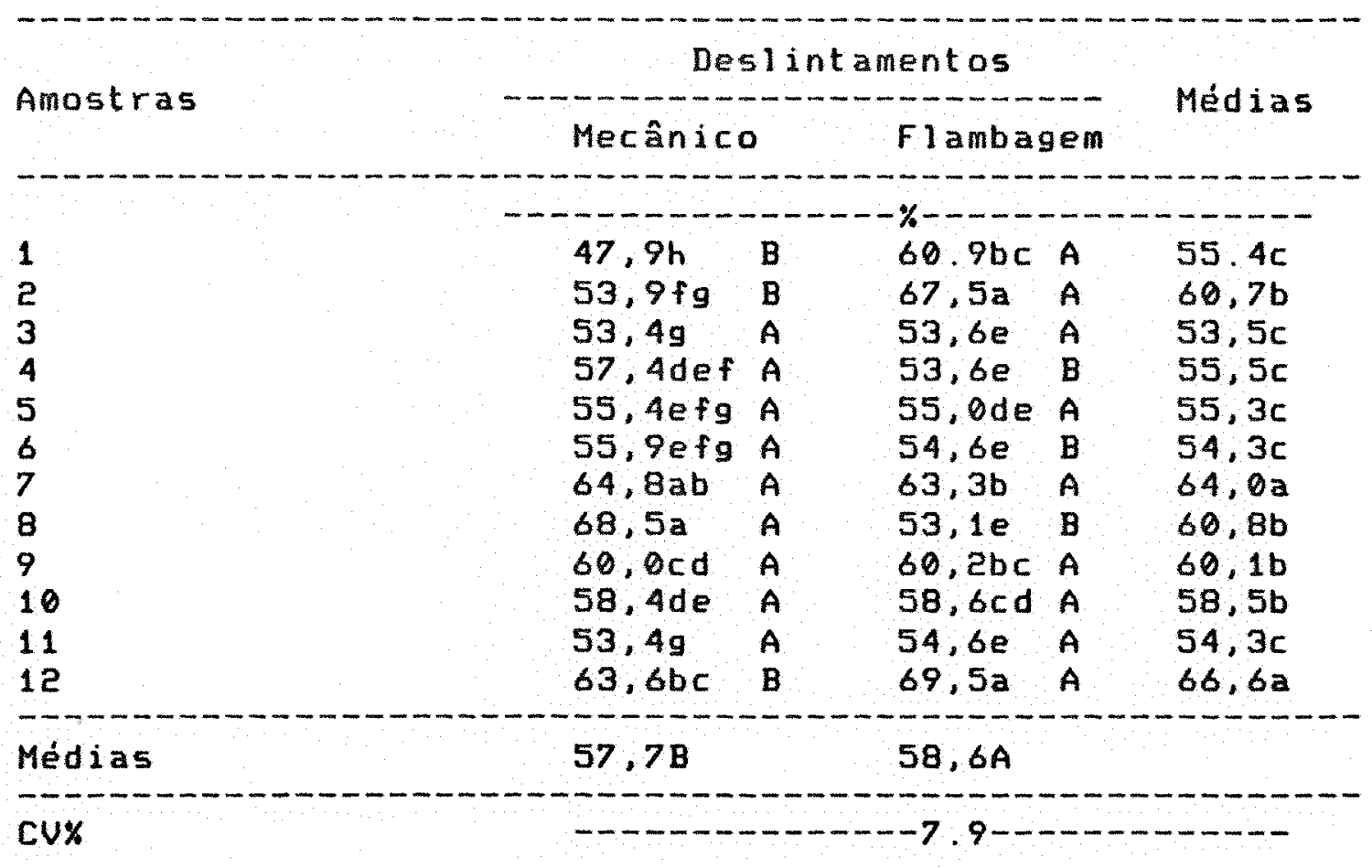

Letras minúsculas comparam médias na vertical e maiúsculas na horizontal.

Médias seguidas pela mesma letra năo diferem entre $5 i$ ao nivel de $5 \%$ de probabilidade pelo teste de Tukey. 
AMOSTRA 1



AMOSTRA 3

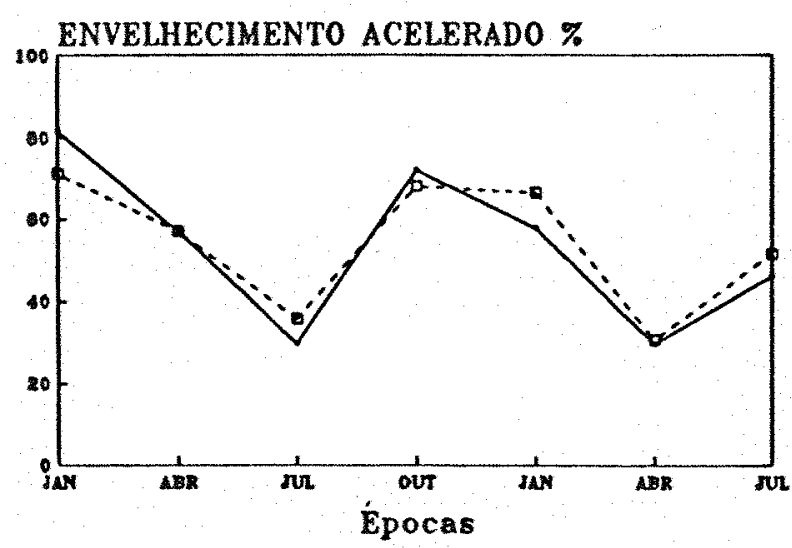

MECÂNICO

AMOSTRA 5

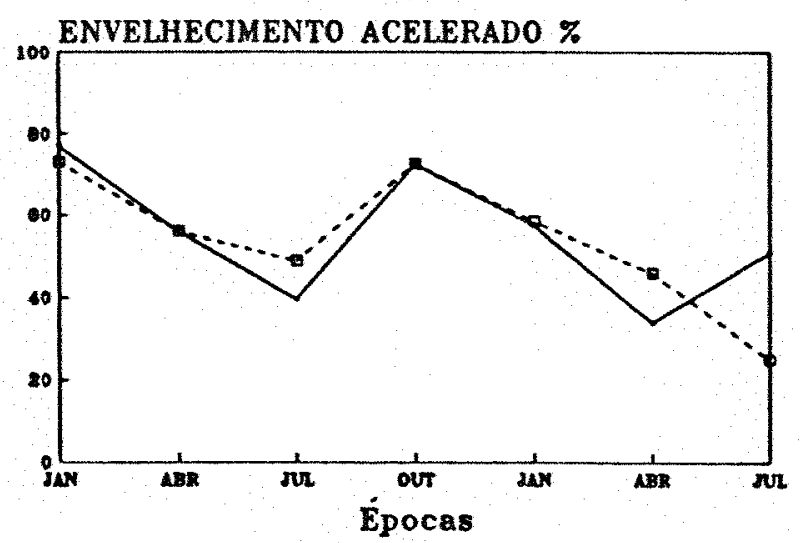

AMOSTRA 2

ENVELHECIMENTO ACELERADO \%

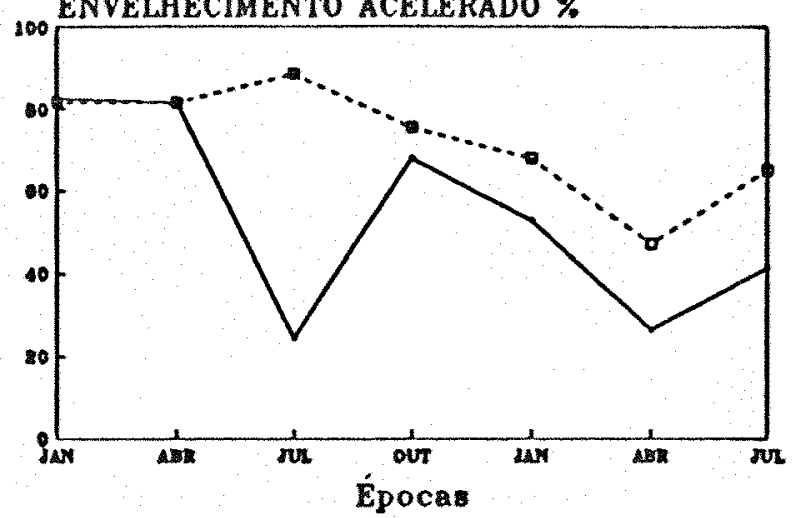

AMOSTRA 4



FLAMBAGEM

AMOSTRA 6



Figura 9. Envelhecimento acelerado das sementes das seis amostras da cultivar IAC-19, submetidas a dois tipos de deslintamento e armazenadas por 18 meses, com avali ação a cada três meses. 



AMOSTRA 9

AMOSTRA 10


MECÂNICO

\section{FLAMBAGEM}

AMOSTRA 11

AMOSTRA 12

ENVELHECIMENTO ACELERADO \%
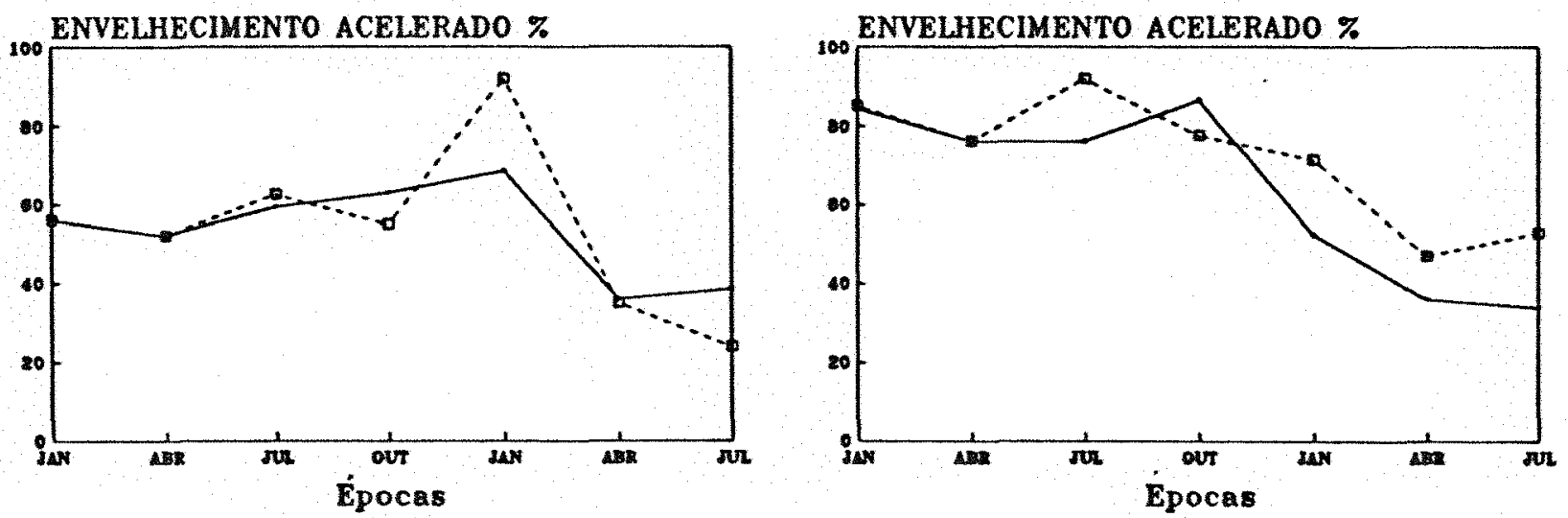

Figura 10. Envelhecimento acelerado das sementes das seis amostras da cultivar IAC-20, submetidas a dois tipos de deslintamento e armazenadas por 18 meses, com avaliacão a cada três meses. 


\subsection{Sanidade:}

Na análise de sanidade foram detectados diversos fungos, vários deles saprófitas; portanto, só foram considerados os fungos patogênicos ao algodoeiro e, frequentemente, detectados em sementes, como colletotrichum gossgpii, Botrsodiplodia sp., Fusalum spp., além dos fungos que prejudicam o armazenamento das sementes como Aspergillus spp. e Fentililium spp.

\subsubsection{Colletotrithum gos gypil}

Os resultados da incidência deste fungo nas sementes estão 1 istados na Tabela 8.

A viabilidade de Colletotrichun gossypit decresceu já nos primeiros três meses de armazenamento das sementes, sendo a morte do fungo mais acentuada nas sementes flambadas. Em abril, julho e outubro de $1988 \mathrm{e} e m$ janeiro de 1989 as sementes deslintadas mecanicamente apresentaram incidencias significativamente superiores deste microrganismo.

Năo houve diferenca entre as médias da incidência de $C$. gossgpili nas amostras das cultivares IAC19 e IAC-20. Amostras com germinąão inicial superior a $85 \%$ não apresentaram diferencas na incidência de colletotrichum 
gossypil quando comparadas com as amostras de germinacão inicial inferior a $85 \%$.

Logo após o deslintamento, o fungo foi encontrado em maior incidencia nas sementes flambadas, possivelmente pela maior facilidade de deteção do mesmo. A retirada parcial do linter expõe a superficie da semente, facilitando a visualizacăo do fungo sob estereomicroscópio. As amostras apresentaram incidencias iniciais entre 0 e $9,4 \%$ de $C$. gosssfil, mas após três meses de estocagem, já estavam com níveis, em geral, mais baixos, entre 0 e $3,5 \%$, indicando que o mesmo perdeu rapidamente a viabilidade, em condicóes de ambiente não controlado. Como pode ser observado nas Fig. 11 e 12, amostras com diferentes indices iniciais apresentaram incidencias semelhantes após 3 meses de estocagem.

Em julho de 1989 o fungo ainda permanecia viável apenas em duas amostras, 2 e 7 , em niveis baixos $(0,2 \%)$

Na Tabela 9 observa-se que o deslintamento a flama não teve influência sobre a presenca de $C$ gossłfili nas sementes nas diversas amostras armazenadas, considerando-se a média de todo o experimento. A amostra 10 mostrou os maiores indices deste fungo e as amostras 5,8 e 9 os menores, destacando-se que a incidência do patógeno foi reducida logo no inicio do armazenamento. 
Tabela 8 . Incidência, durante o armazenamento por 18 meses em condicốes de ambiente não controlado, de Colletotrichum gossypii em sementes de algodão (Método do papel de filtro, 7 dias de incubacão) submetidas a dois tipos de deslintamento. Resultados são médias de doze amostras de sementes.

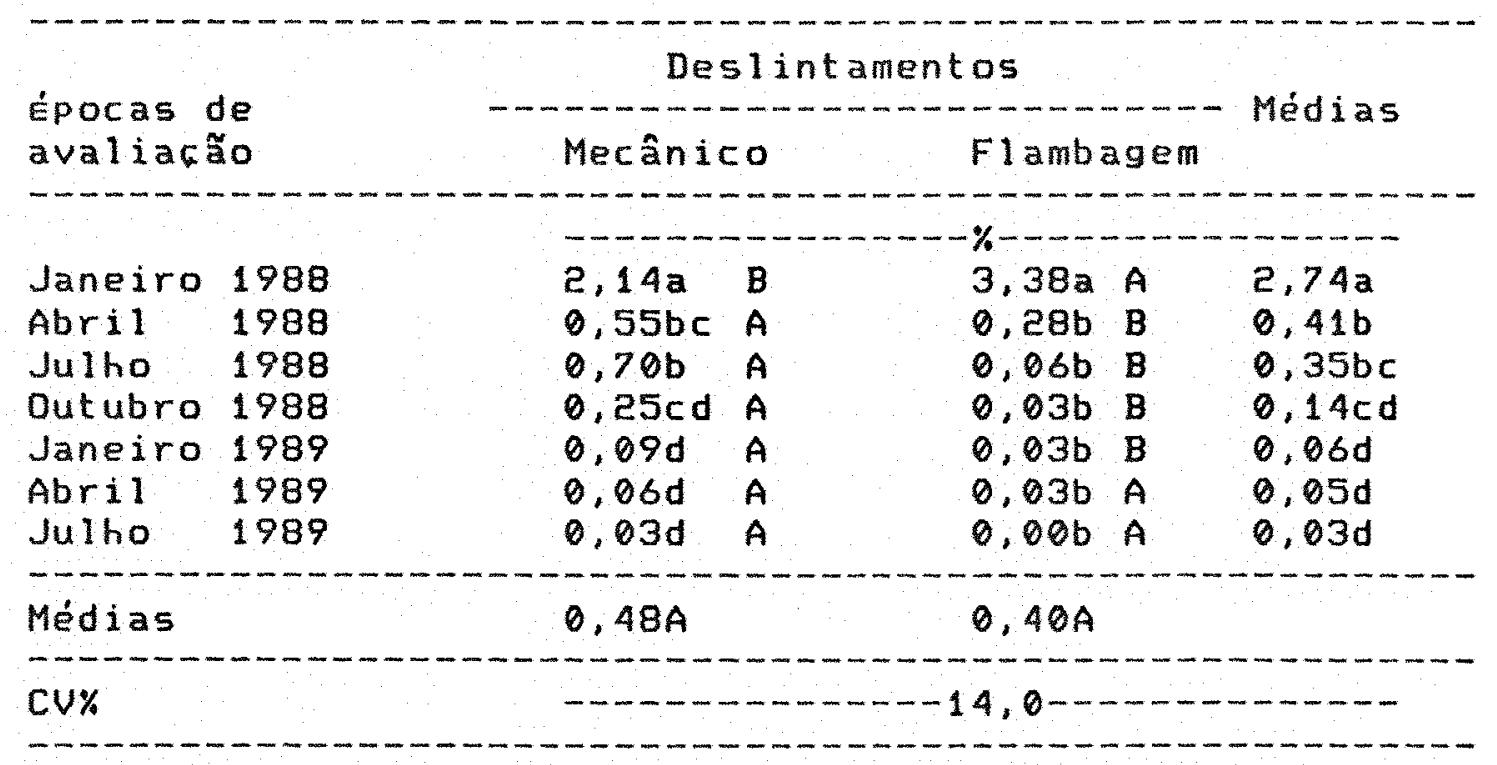

Letras minúsculas comparam médias na vertical e maísculas na horizontal.

Médias seguidas pela mesma letra não diferem entre si ao nivel de $5 \%$ de probabilidade pelo teste de Tukey. 
Tabela 9. Incidencia média de Colletatrithum gossyfil em sementes de algodão durante 18 meses de armazenamento sob condicões de ambiente não controlado.



Letras minúsculas comparam médias na vertical.

Médias seguidas pela mesma letra não diferementre si ao nivel de $5 \%$ de probabilidade pelo teste de Tukey. 

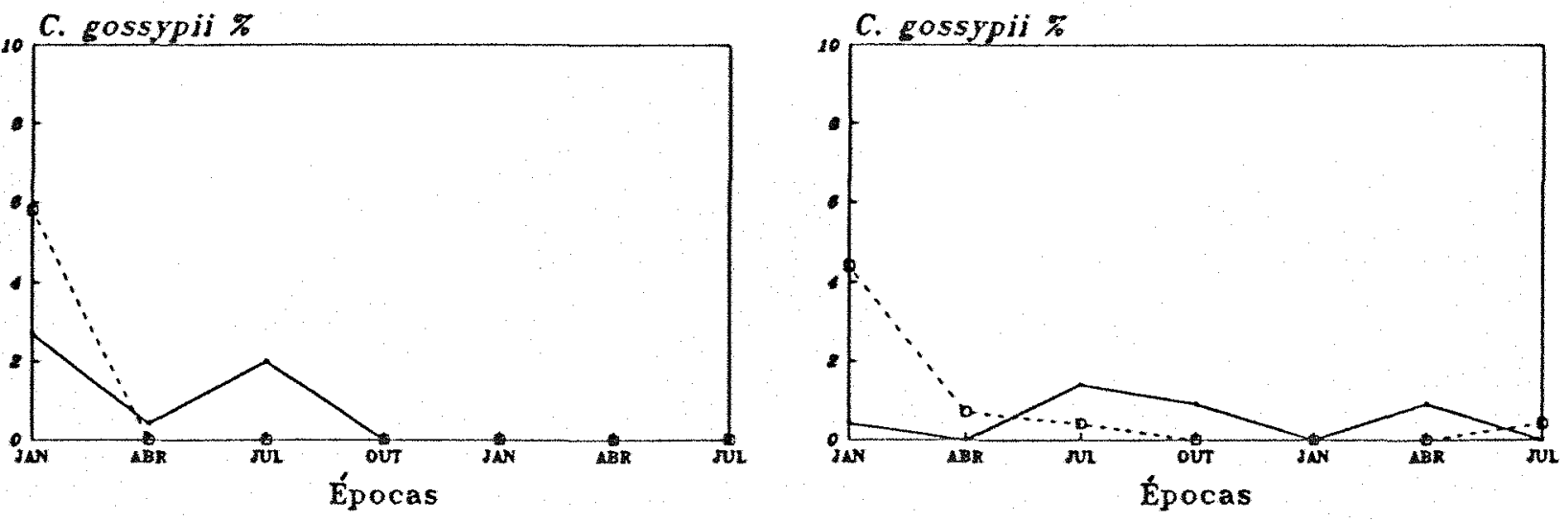

AMOSTRA 3

AMOSTRA 4


MECÂNICO

FLAMBAGEM

AMOSTRA 5

AMOSTRA 6
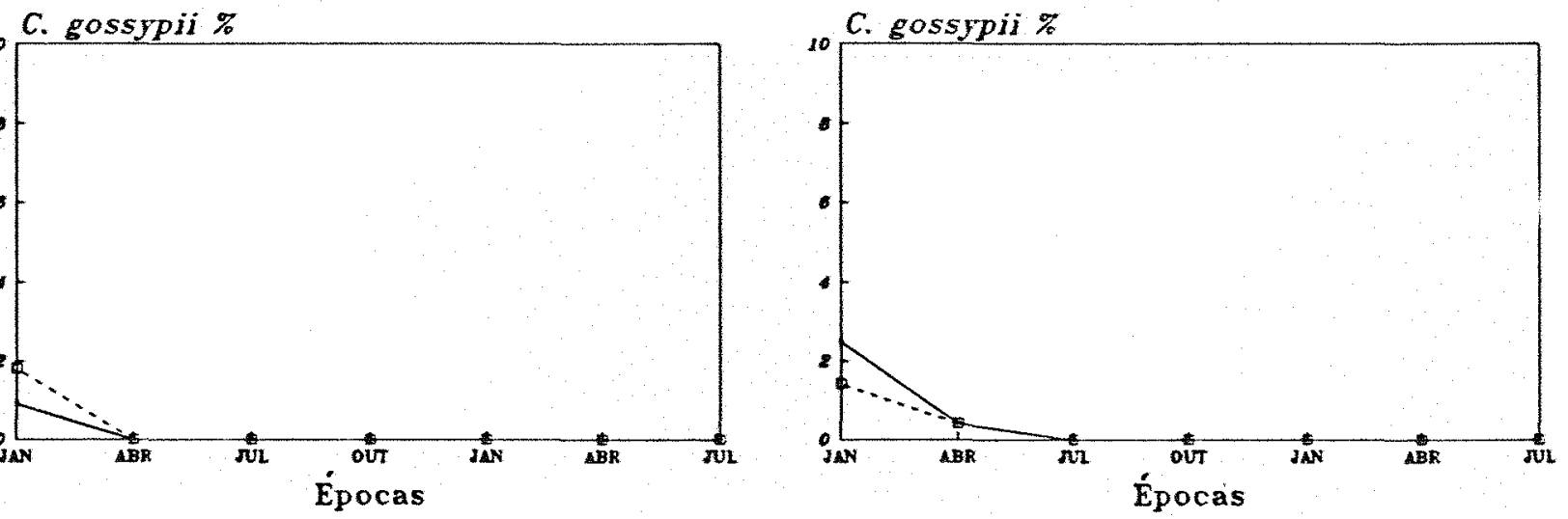

Figura 11. Incidencia de colletotrichum gossypii em sementes de algodão nas amostras da cultivar IAC-19, submetidas a dois tipos de deslintamento, durante o armazenamento por 18 meses em condicôes de ambiente não controlado. 

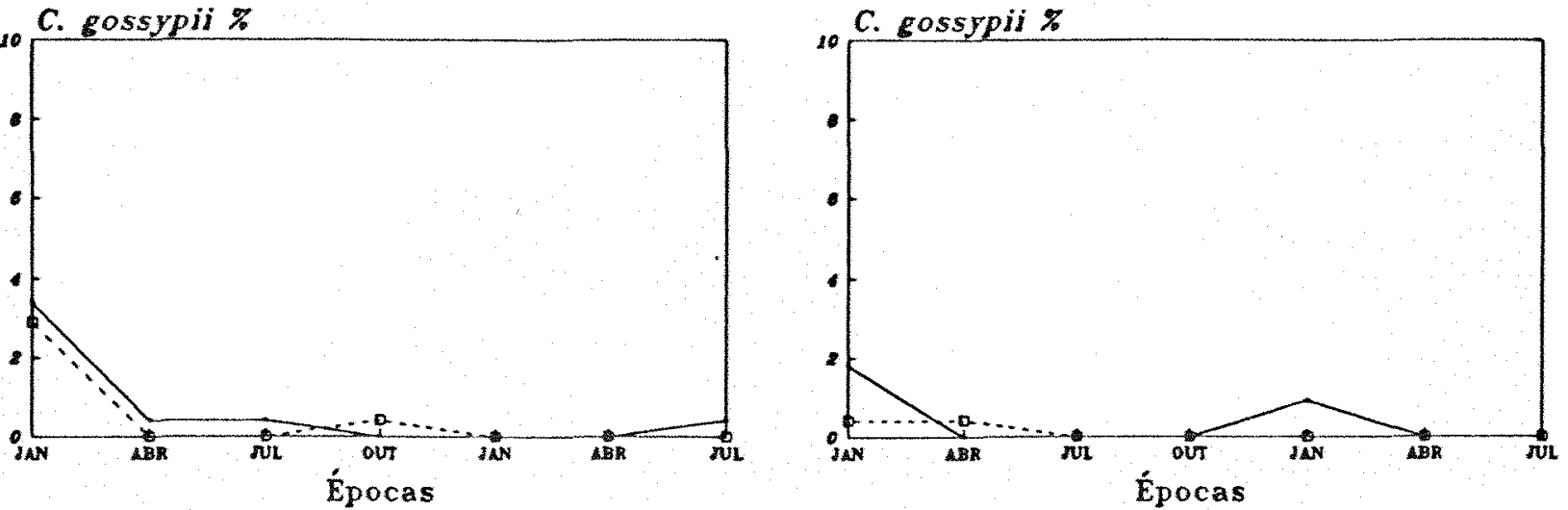

AMOSTRA 9

AMOSTRA 10
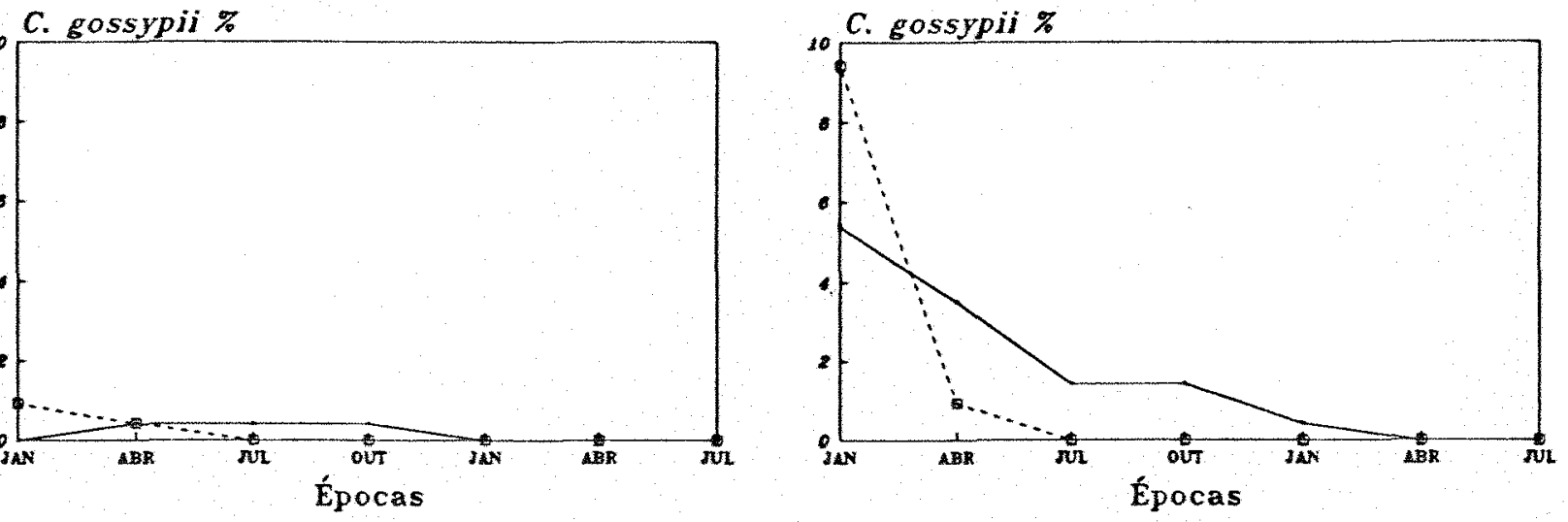

FLAMBAGEM

AMOSTRA 11

AMOSTRA 12
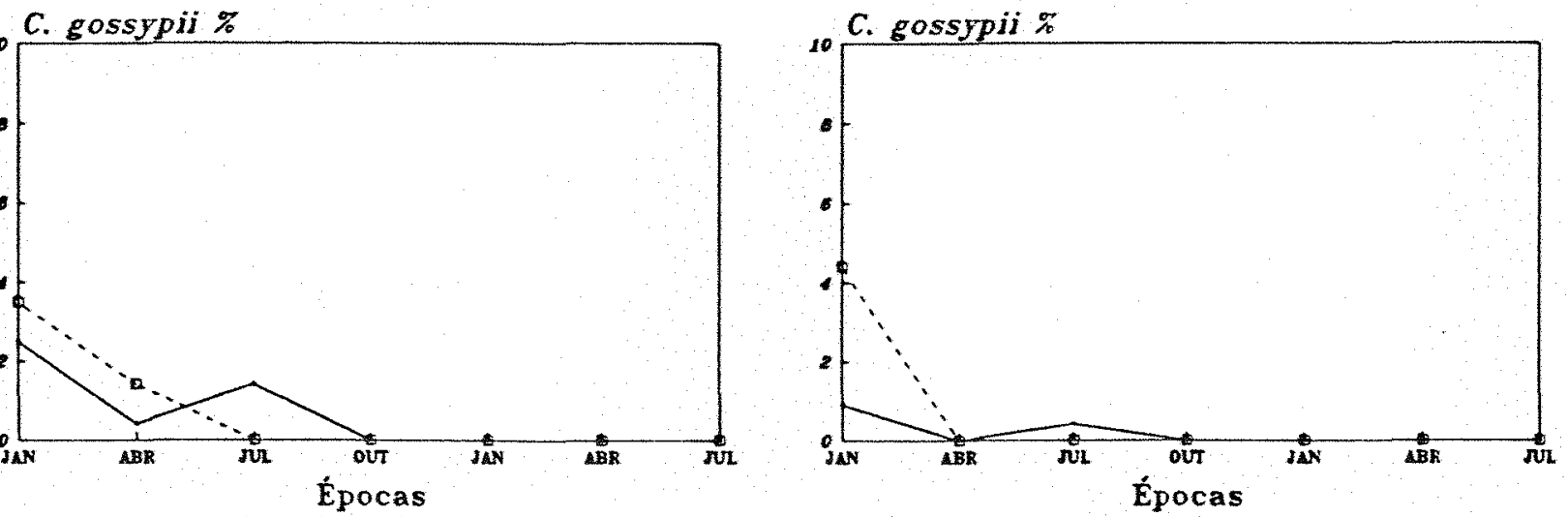

Figura 12. Incidência de Colletotrithum gossypii em sementes de algodâo nas amostras da cultivar IAC-20, submetidas a dois tipos de deslintamento, durante o armazenamento por 18 meses em condicôes de ambiente não controlado. 
É necessário lembrar que estas sementes foram colhidas em abril e maio de 1987. Embora as sementes tenham permanecido em câmara fria e seca de setembro a dezembro de 1987, o decréscimo na viabilidade de $C$. gosgypil nas mesmas deve ter ocorrido a partir da colheita. Detectou-se neste trabalho o final da curva de decréscimo na viabilidade do fungo, pois as análises tiveram início em janeiro de 1988.

Como já havia sido demonstrado por LUWIG (1924), ARNDT (1946) e, para c. gossgfil var Eephalosporioides, por LIMA et alii (1988), o fungo Colletotrithum gossgail perdeu a viabilidade rapidamente durante o armazenamento. Se as sementes armazenadas fossem plantadas na safra seguinte, outubro de 1988, o microrganismo estaria presente em taxas não expressivas nas mesmas.

\subsubsection{Fusarium SPP.}

As principais espécies de Fusarlum, observadas nas sementes, foram $F$. moniliforme, $F$, semitertum e $F$. equiseti, além de outras espécies com ocorrência ocasional, não identificadas. Como estas espécies possuem Patogenicidade semelhante (PIZZINATTO, 1989), as mesmas foram agrupadas para análise dos dados.

Ds resultados da incidencia das diversas espécies de Fusarium que ocorreram nas sementes estão 
listados na Tabela 10. Este fungo também teve a incidência reduzida durante o armazenamento, e o decréscimo mais expressivo ocorreu após o mês de julho de 1988.

As sementes deslintadas mecanicamente permaneceram, durante todo o periodo de armazenamento, com maior incidência de fusarium spp., com excefão de janeiro e outubro de 1988, quando não houve diferenca entre os deslintamentos.

Quando se comparou a incidência deste microrganismo nas seis amostras da cultivar IAC-19, com as seis amostras da cultivar IAC-20, através do teste $F$ de contraste entre as médias, verificou-se que as amostras da cultivar IAC-19 (média de $2,85 \%$ ) apresentaram niveis significativamente superiores de Fusarium spP. aos das amostras da cultivar IAC-20 (média de $2,42 \%$ ).

Amostras com germinação inicial superior a $85 \%$ mostraram, através do teste $F$ de contraste entre as médias, incidencia significativamente inferior (média de 2,41 ) de Fusarium SpP. à das amostras com germinacão abaixo de $85 \%$ (média de 2,86 ).

$\mathrm{Na}$ instalacão do experimento, as incidências variaram entre 0,9 e $11,9 \times$ sem que houvesse diferenca entre os deslintamentos. Após 3 meses de armazenamento quando houve decréscimo na quantidade de Fusariua SPP. nas sementes, o fungo teve a sua viabilidade reduzida mais rapidamente nas sementes flambadas. Nas sementes que 
sofreram apenas deslintamento mecânico, ocorreu decréscimo a partir de julho de 1988 . Se as sementes fossem plantadas na safra seguinte (outubro de 1988) estariam com niveis baixos de Fusarium spp., entre 0,4 e $3,7 \%$, que possivelmente não provocariam danos à emergencia das mesmas. Este fungo sobreviveu nas sementes por um periodo mais longo que $E$. gossypit, talvez porque tenha ocorrido em niveis iniciais mais elevados, ou por estar localizado mais internamente na semente, ou ainda porque é mais resistente à estocagem. RONCADORI et alii (1971) também observaram decréscimo na viabilidade deste fungo em sementes de algodão, quando armazenadas por 5 meses; o total de Fusarium spp. decresceu nas sementes de 36,1 para $22,3 \%$ e ao separar o embrião, de 13 para $9,5 \%$. Como estes autores observaram, grande parte do inóculo de Fusarium pode estar no interior da semente, onde o mesmo sobrevive por mais tempo, o que pode ter ocorrido neste trabalho, no qual a local ização do fungo não foi determinada.

Na Tabela 11 verifica-se que as amostras 10, 3 e 1 apresentaram, na média, os maiores indices de fusarium spp. e a amostra 12 o menor nivel do fungo. Com excecão das amostras 2, $7,8,9$ e 10 , este patógeno ocorreu em menores proporcões nas sementes flambadas.

Nas amostras 1,2 e 5 (Fig. 13 e 14) foi detectado um aumento na quantidade de Fusarium nas sementes flambadas no mês de abril de 1989. Esse aumento pode ser 
atribuido a uma contaminacão em laboratório. Pode ainda ser aventada a hipótese da maior incidência deste patógeno ser devida à morte de possiveis antagonistas neste periodo de armazenagem.

4.4.3. Sotryodiflodia sp.

Ds resultados da média da incidência deste microrganismo nas sementes estão descritos na Tabela 12.

Gofigodiflodia SP. usualmente ocorre em pequenas quantidades nas sementes de algodão. Como para $C$. gosgypil e Fusalium spP. , houve decréscimo na incidência deste fungo durante o armazenamento; entretanto algumas amostras ainda estavam contaminadas após o periodo de 18 meses de estocagem.

Não ocorreram diferencas nas quantidades encontradas deste microrganismo entre sementes flambadas e deslintadas mecanicamente (Tab. 12 e 13). Também não houve diferenca na incidencia de sotryodiflodia sp. entre as amostras das cultivares IAC-19 e IAC-20, quando comparadas através do teste $F$ de contraste entre as médias. 
Tabela 10. Incidência, durante o armazenamento por 18 meses em condicóes de ambiente não controlado, de Fusiariun spP. em sementes de algodão (Método do papel de filtro, 7 dias de incubacão) submetidas a dois tipos de deslintamento. Resultados são médias de doze amostras de sementes.

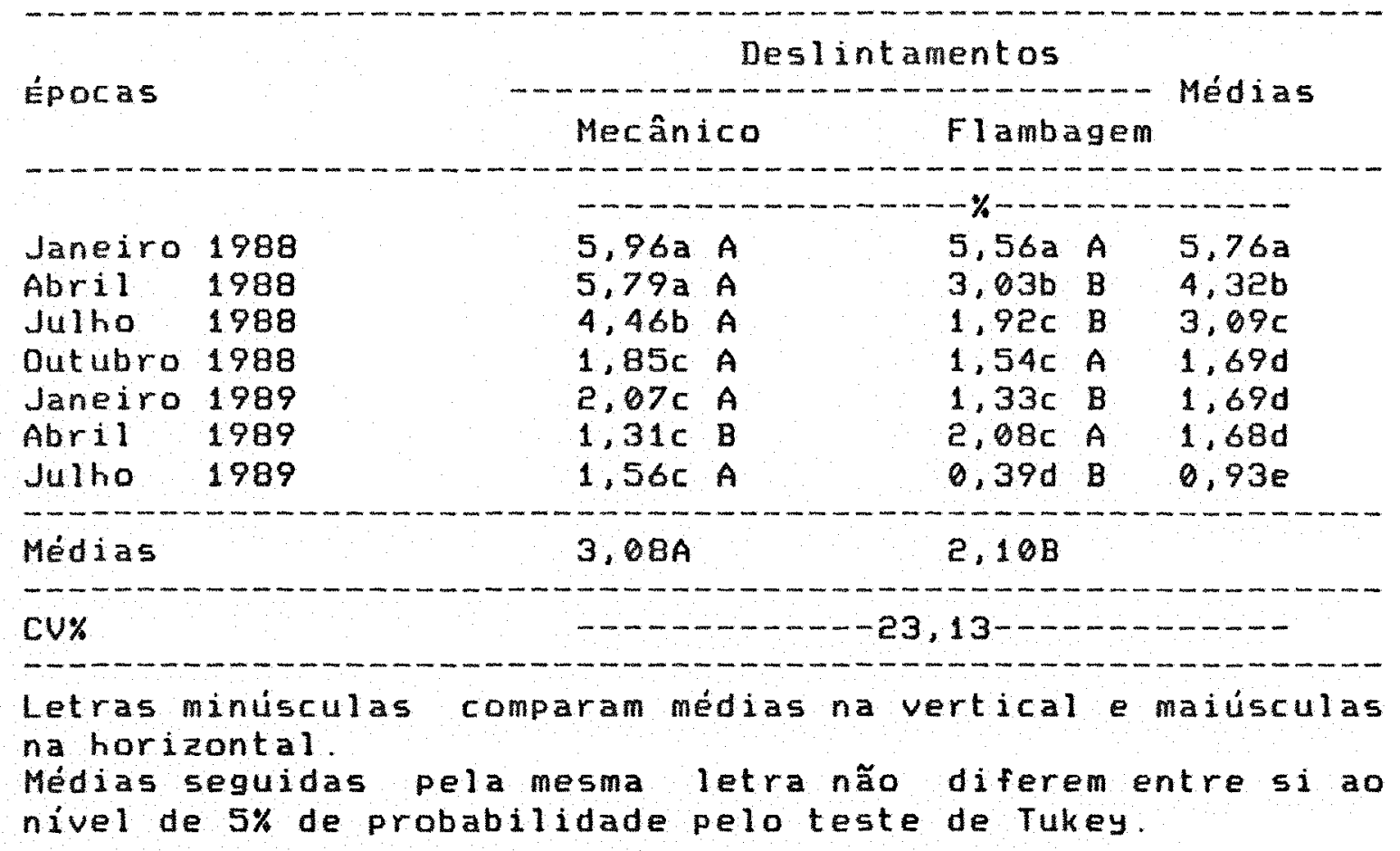


Tabela 11. Incidência média de Fusarium spp. em sementes de algodão durante 18 meses de armazenamento sob condicốes de de ambiente não controlado.

\begin{tabular}{|c|c|c|c|c|c|}
\hline \multirow[b]{2}{*}{ Amostras } & \multicolumn{4}{|c|}{ Deslintamentos } & \multirow[b]{2}{*}{ Médias } \\
\hline & \multicolumn{2}{|c|}{ Mecânico } & \multicolumn{2}{|c|}{ Flambagem } & \\
\hline & \multicolumn{5}{|c|}{ 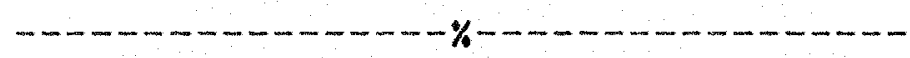 } \\
\hline 1 & $4,6 \mathrm{a}$ & A & $2,6 b$ & $\mathbf{B}$ & $3,6 \mathrm{ab}$ \\
\hline 2 & $3,0 \mathrm{bcd}$ & A & $2,2 b$ & A & $2.8 \mathrm{bcd}$ \\
\hline 3 & $3,9 a b c$ & A & $2,4 b$ & B & $3,1 \mathrm{bc}$ \\
\hline 4 & $3,3 b c d$ & A & $2,2 b$ & B & $2,7 \mathrm{bcd}$ \\
\hline 5 & $3,4 a b c d$ & A & $2,3 b$ & B & 2, Bbcd \\
\hline 6 & 3, ebcd & A & $1,4 \mathrm{bcd}$ & B & $2,3 c d$ \\
\hline 7 & $1,3 f$ & A & $0.9 \mathrm{~cd}$ & A & $1,0 \mathrm{e}$ \\
\hline 8 & 2,0 def & A & $2,0 \mathrm{bc}$ & A & $2,0 d$ \\
\hline 9 & $2,5 c d e$ & A & $2,5 b$ & A & $2,5 b c d$ \\
\hline 10 & $5,0 \mathrm{a}$ & A & $4,3 a$ & $A$ & $4,6 a$ \\
\hline 11 & $4,3 a b$ & $A$ & $2,2 b$ & $B$ & 3, $\mathrm{ebc}$ \\
\hline 12 & $1,5 \mathrm{ef}$ & A & $0,7 d$ & B & $1,0 \mathrm{e}$ \\
\hline \multicolumn{6}{|c|}{$\begin{array}{lll}\text { Médias } & 3,08 \mathrm{~A} & 2,10 \mathrm{~B}\end{array}$} \\
\hline CV\% & $\ldots-\cdots$ & 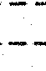 & $--23,1$ & $1-1$ & $\cdots-\cdots$ \\
\hline
\end{tabular}

Letras minúsculas comparam médias na vertical e maiúsculas na horizontal.

Médias seguidas pela mesma letra não diferem entre si ao nivel de $5 \%$ de probabilidade pelo teste de Tukey. 
Fusarium spp \%

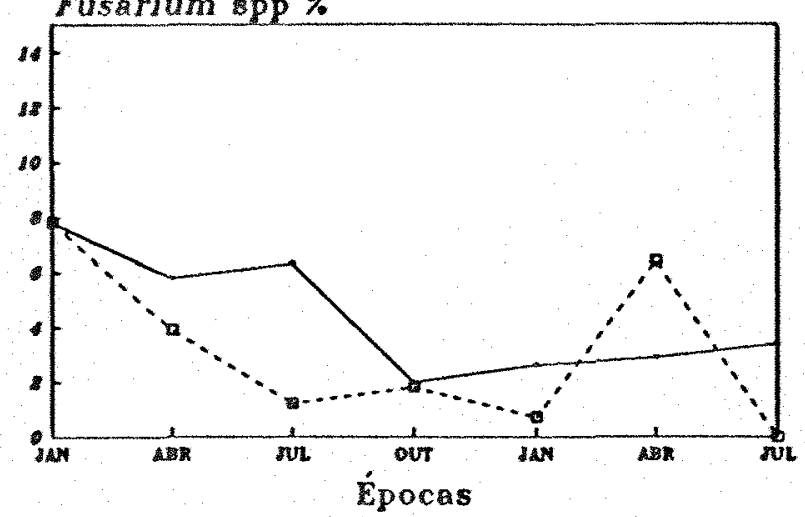

AMOSTRA 3

Fusarium spp \%

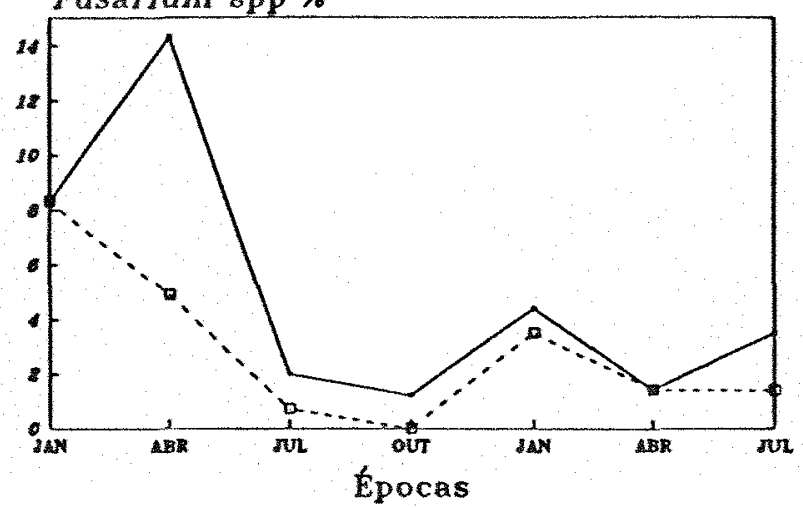

MECÂNICO

AMOSTRA 5

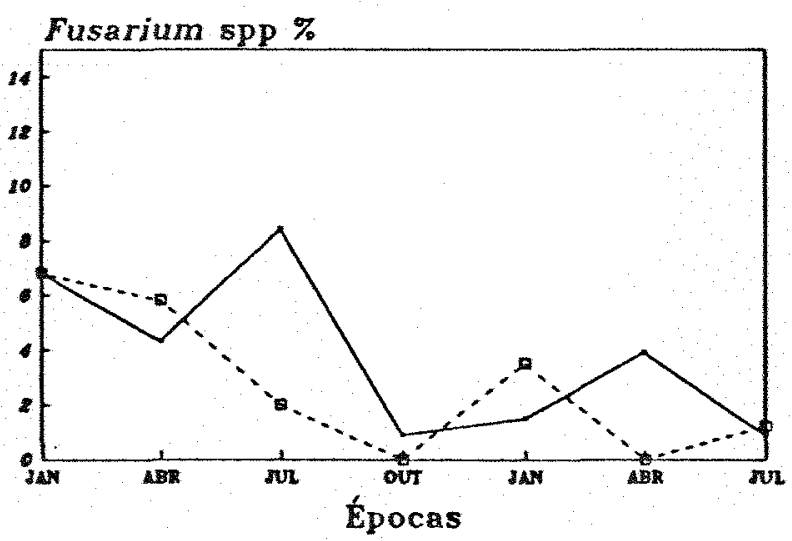

Fusarium op \%

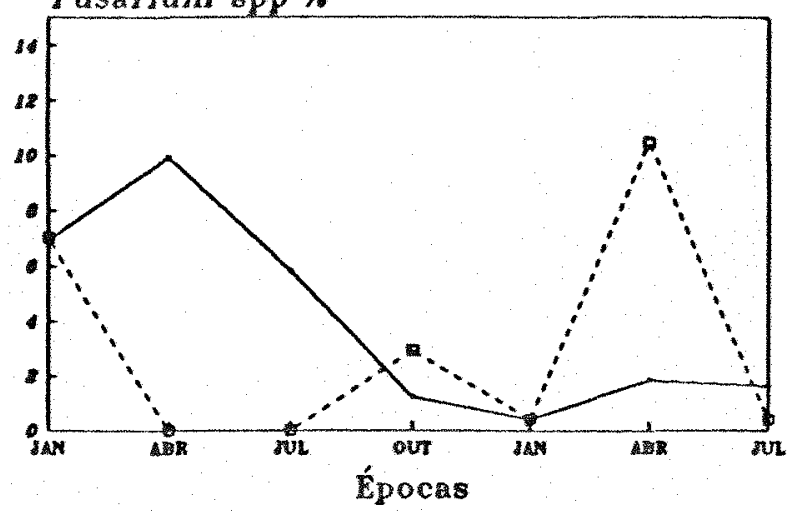

AMOSTRA 4

Fusarium spp \%

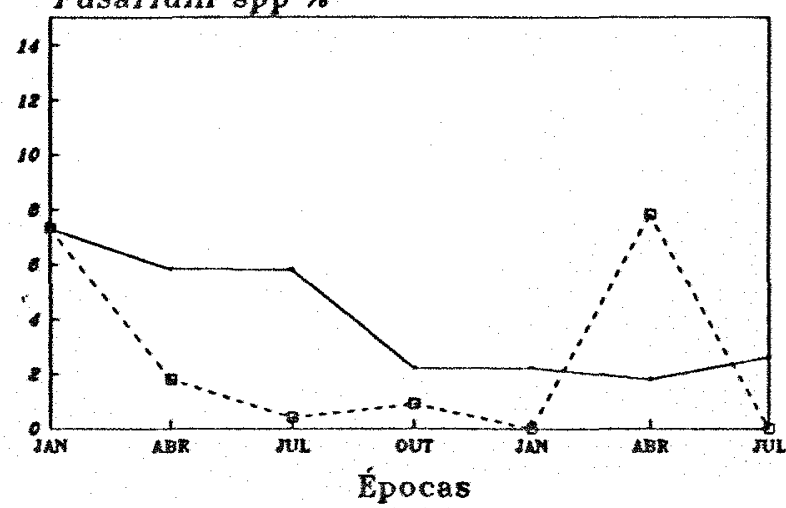

FLAMBAGEM

AMOSTRA 6

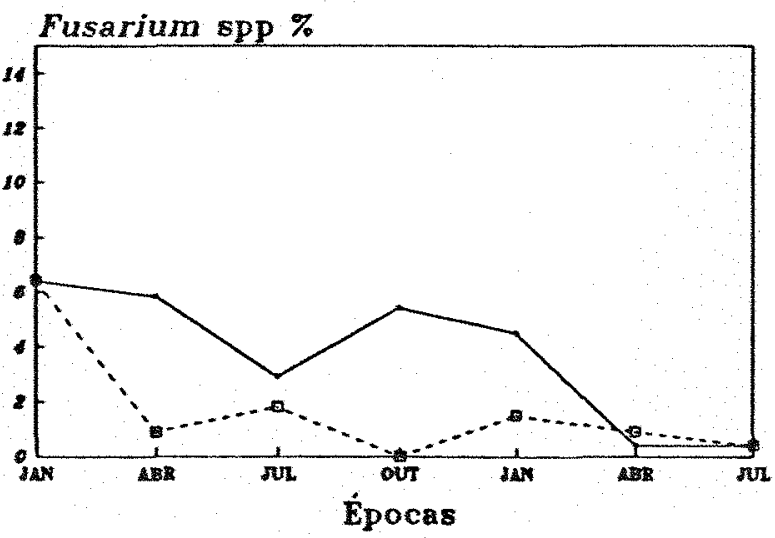

Figura 13. Incidencia de Fusarium spp. em sementes de algodão nas seis amostras da cultivar IAC-19, submetidas a dois tipos de deslintamento durante o armazenamento por 18 meses em condicões de ambiente năo controlado. 
Fusarium spp $\%$

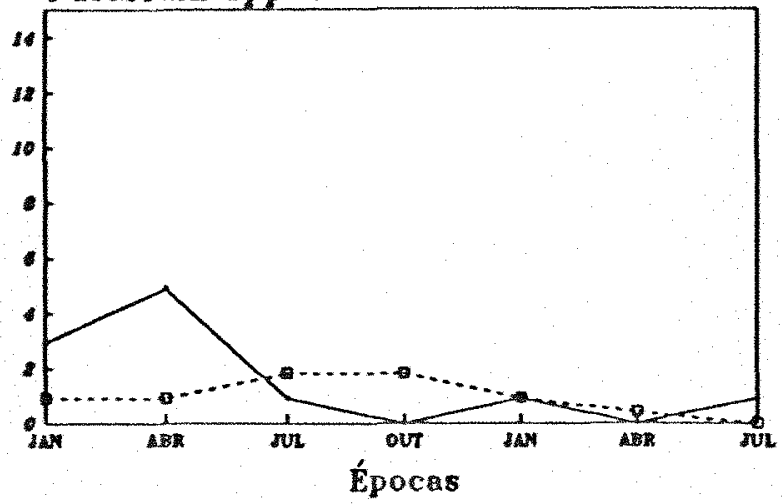

AMOSTRA 9

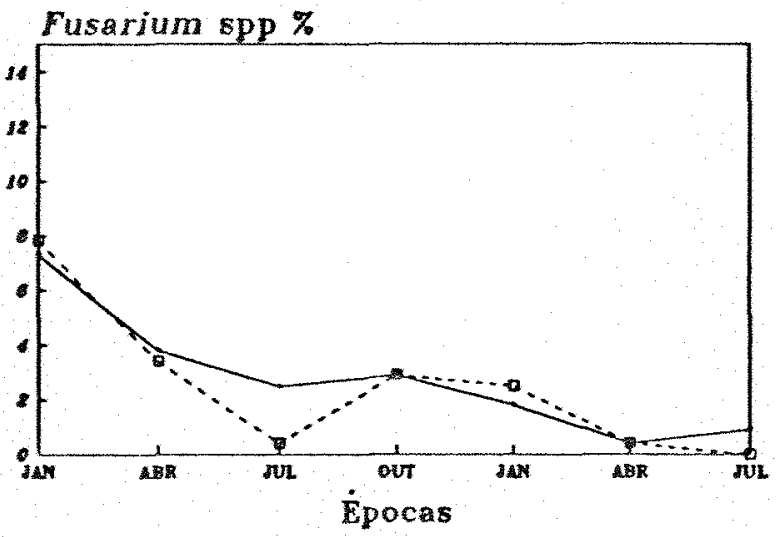

MECÂNICO

AMOSTRA 11

Fusarium spp $\%$



Fusarium spp \%

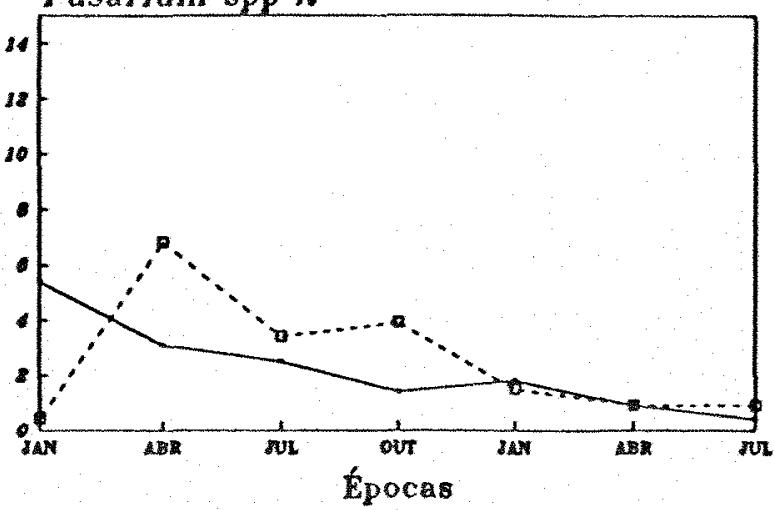

AMOSTRA 10



FLAMBAGEM

AMOSTRA 12



Figura 14. Incidência de Fusarium spp. em sementes de algodão nas seis amostras da cultivar IAC-20. submetidas a dois tipos de deslintamento. durante o armazenamento por 18 meses em condicốes de ambiente não controlado. 
Embora Botrsodiplodia sp. seja um fungo frequente em sementes de algodão, sua incidência nas sementes foi bem menor que a dos fungos anteriores. Na instalacão do experimento, variou entre 0 e $2,3 \%$ (Fig. 13 e 14). Nesta primeira época as sementes flambadas apresentaram niveis maiores, talvez pela maior facilidade de detecaão, o contrário ocorrendo nos meses de abril e julho do mesmo ano. A retirada parcial do linter expốa a superficie da semente, facilitando a visualizacão do fungo sob estereomicroscópio. Após jultho de 1988, as incidencias foram extremamente baixas. Surpreendentemente, na ultima avaliagão (julho de 1989) três amostras ainda apresentaram Botryodiflodia sp., indicando que, mesmo em niveis baixos, - fungo póde sobreviver por até 18 meses nas sementes (Fig. 13 e (4).

Comparando-se a incidência do fungo entre as amostras (Tabela 13), verifica-se que não houve diferenca entre sementes flambadas e deslintadas mecanicamente. As amostras 10 e 11 apresentaram os maiores niveis de Eotryodiflodia sp. e, as amostras 1,5 e 12, os menores valores.

Amostras com germinacão inicial maior que $85 \%$ mostraram incidência, através do teste $F$ de contraste entre as médias, significativamente inferior (média de $0,10 \%$ ) de Botryodiflodia sp. à das amostras com germinacăo inicial inferior a $85 \%$ (média de $0,20 \%$ ). 
Tabela 12. Incidência, durante 18 meses de armazenamento em condicões de ambiente não controlado, de Botryodiplotia $5 \mathrm{P}$. em sementes de algodão (Método do papel de filtro, 7 dias de incubacão) submetidas a dois tipos de deslintamento. Resultados são médias de doze amostras de sementes.



Letras minúsculas comparam médias na vertical e maiúsculas na horizontal.

Médias seguidas pela mesma letra não diferem entre si ao nivel de $5 \%$ de probabilidade pelo teste de Tukey. 
Tabela 13. Incidência média de Batryodiplodia sp. em sementes de algodão durante 18 meses de armazenamento sob condicóes de ambiente não controlado.




4.4.4. Aspergillas spp.

As médias de incidência de Aspergillus spp. estão listadas nas Tabelas 14 e 15.

A incidência foi variável nas diversas épocas de avaliacão das sementes, sendo a mais baixa em janeiro de 1988 e a mais elevada em julto de 1989 . Em outubro de 1988 diminuiu a quantidade encontrada deste fungo, que voltou a crescer nos meses subsequentes.

As sementes deslintadas mecanicamente apresentaram, em todo o periodo, niveis significativamente maiores de Aspelgillus spp. do que as flambadas, com excecão do inicio do experimento (janeiro de 1988), quando - contrário ocorreu.

Quando se comparou a incidencia deste microrganismo nas amostras da cultivar IAC-19 em relação às amostras da cultivar IAC-20, através do teste $F$ de contraste, verificou-se que as sementes da cultivar IAC-2O apresentaram quantidades significativamente superiores (média de $7,47 \%$ ) às das amostras da cultivar IAC-19 (média de $3,71 \%$ ). Este fato pode se dever à diferenca entre as cultivares quanto à resistência ao fungo, ou a diferentes indices iniciais do patógeno nas sementes.

Na Tabela 15, verifica-se que as amostras 10 e 11 apresentaram os maiores indices deste fungo $e$ as amostras 12, 2, 4 e 5, os menores niveis. Para todas as 
amostras, com exceção da amostra 11, foi detectada maior quantidade de Asfergillus spp. en sementes deslintadas mecanicamente. Provavelmente esta diferenca no desenvolvimento de espécies de Aspergillus durante o armazenamento, tenha ocorrido porque as sementes flambadas permaneceram, durante todo o periodo, com umidade mais baixa.

Observando-se as amostras isoladamente (Fig. 15 e 16) verifica-se que houve um grande desenvolvimento de espécies de Aspergillus em julho de 1988 nas sementes da cultivar IAC-20, com deslintamento mecânico. 0 aumento na quantidade de Asfergillus SPP. no mês de juitho de 1988 , com - subsequente decréscimo na avaliacão seguinte coutubro de 1988) pode ser devido às condicôes climáticas do periodo, pois a umidade relativa média (Figura 1) de janeiro a julho de 1988 foi elevada, mas foi baixa de julto a outubro do mesmo ano. A umidade das sementes acompanhou a flutuacão na umidade relativa do ar, o que já havia sido demonstrado por SIMPSON (1944).

Sabe-se que a ocorrência de espécies de Aspergillus em sementes armazenadas é dependente da umidade das mesmas. Não foram encontrados dados especificos para algodão, mas para outras culturas oleaginosas como soja, quando as sementes estão com $12-13 \%$ de umidade $(65-70 \%$ de UR) os fungos que se desenvolvem são Aspergillus halofilicus; com umidade entre $13-14 \%(70-75 \%$ de UR), A. 
Tabela 14. Incidência de Aspelyillus spp., durante o armazenamento por 18 meses em condicões de ambiente não controlado, em sementes de algodão (Método do papel de filtro, 7 dias de incubaçăo), submetidas a dois tipos de deslintamento. Resultados são médias de doze amostras de sementes.




Tabela 15. Incidência média de Asfergillas spp. em sementes de algodão durante 18 meses de armazenamento sob condicões de ambiente não controlado.

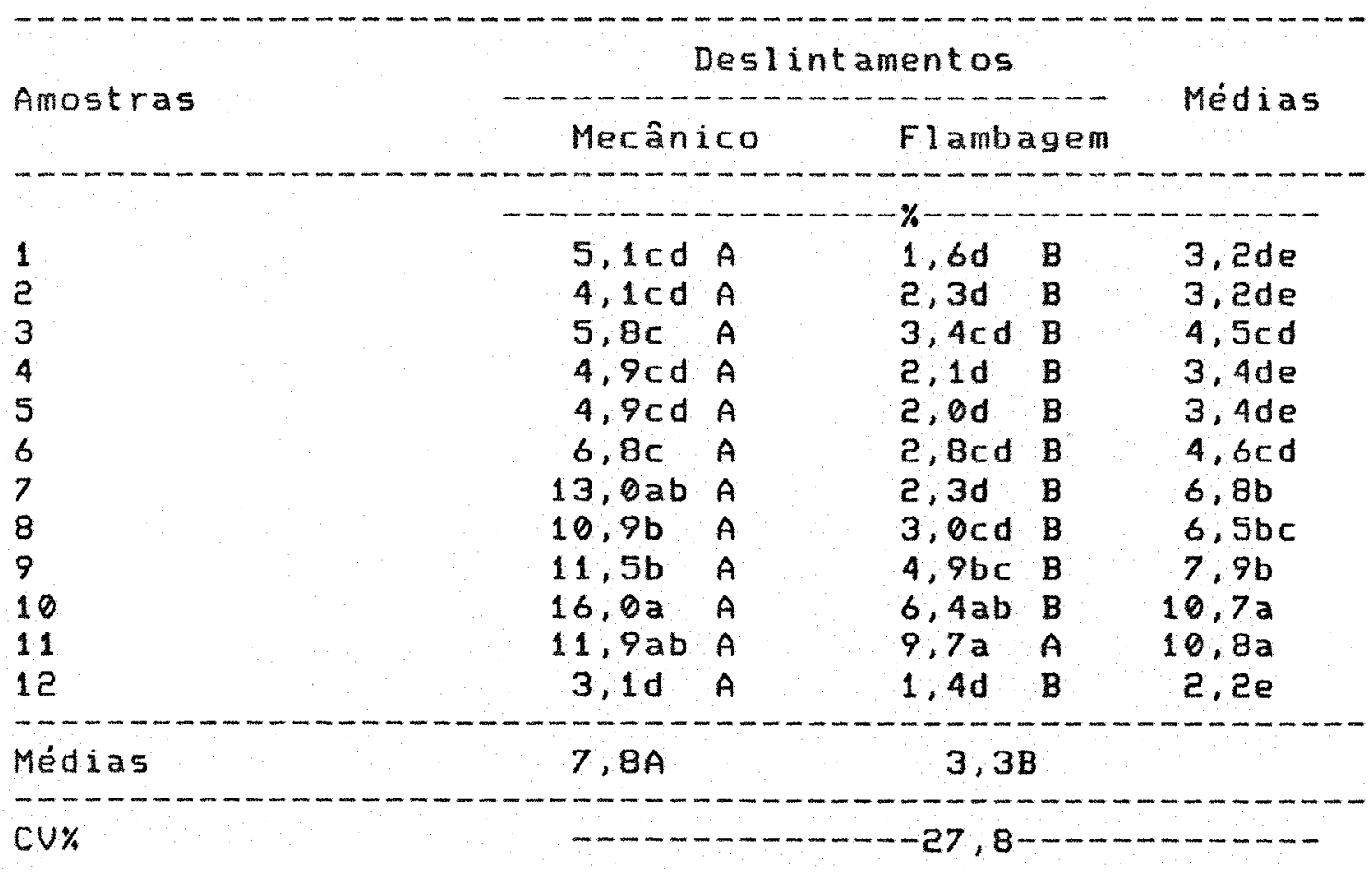

Letras minúsculas comparam médias na vertical e maiúsculas na horizontal.

Médias seguidas pela mesma letra não diferementre si ao nivel de $5 \%$ de probabilidade pelo teste de Tukey. 

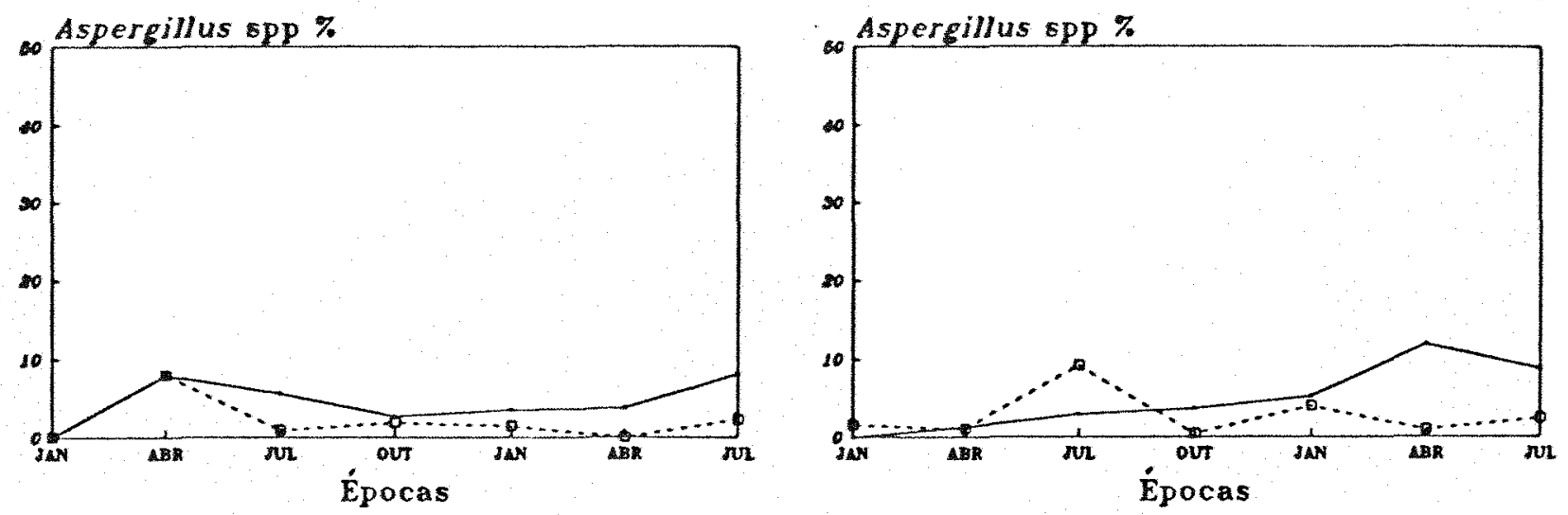

\section{AMOSTRA 3}



MECÂNICO

AMOSTRA 5

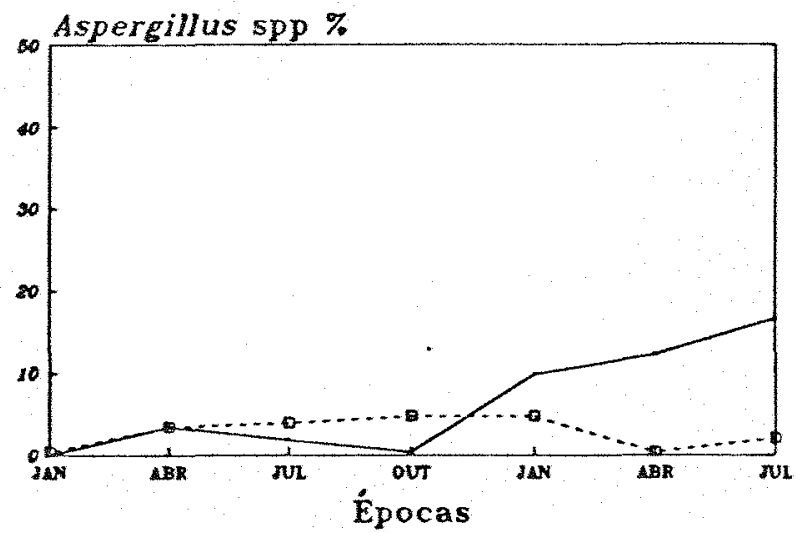

\section{FLAMBAGEM}

AMOSTRA 6
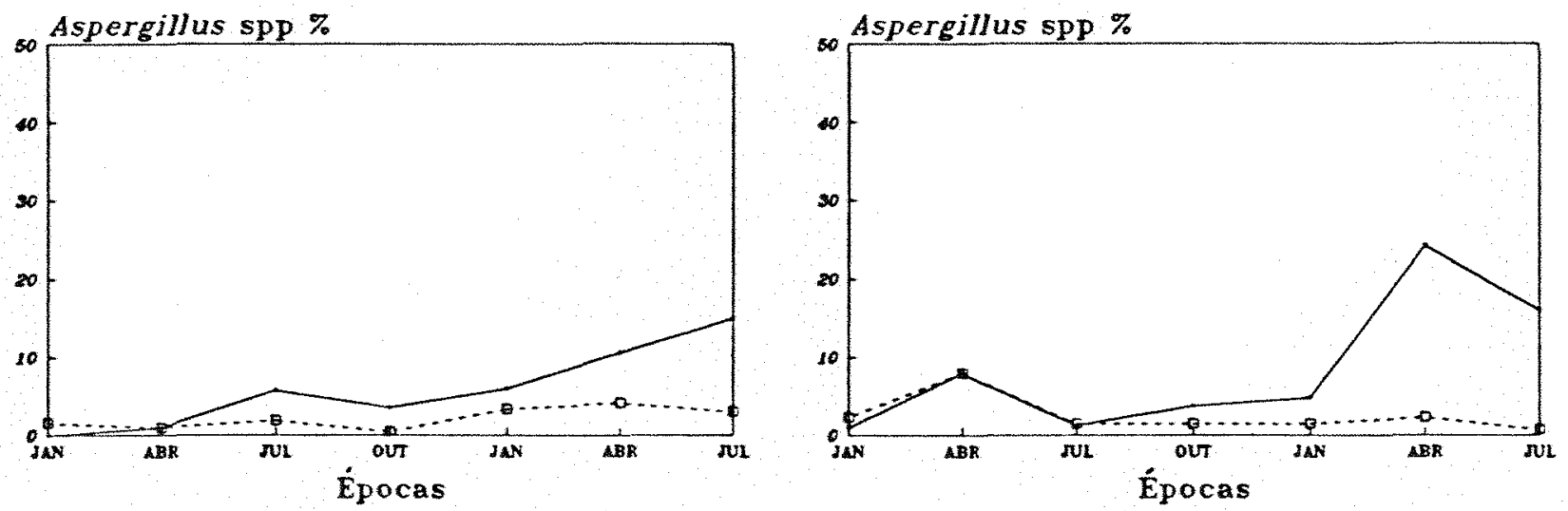

Figura 15. Incidência de Aspergillus spp em sementes de algodão, nas seis amostras da cultivar IAC-19, submetidas a dois tipos de deslintamento. durante 0 armazenamento por 18 meses em condicões de ambiente não controlado. 

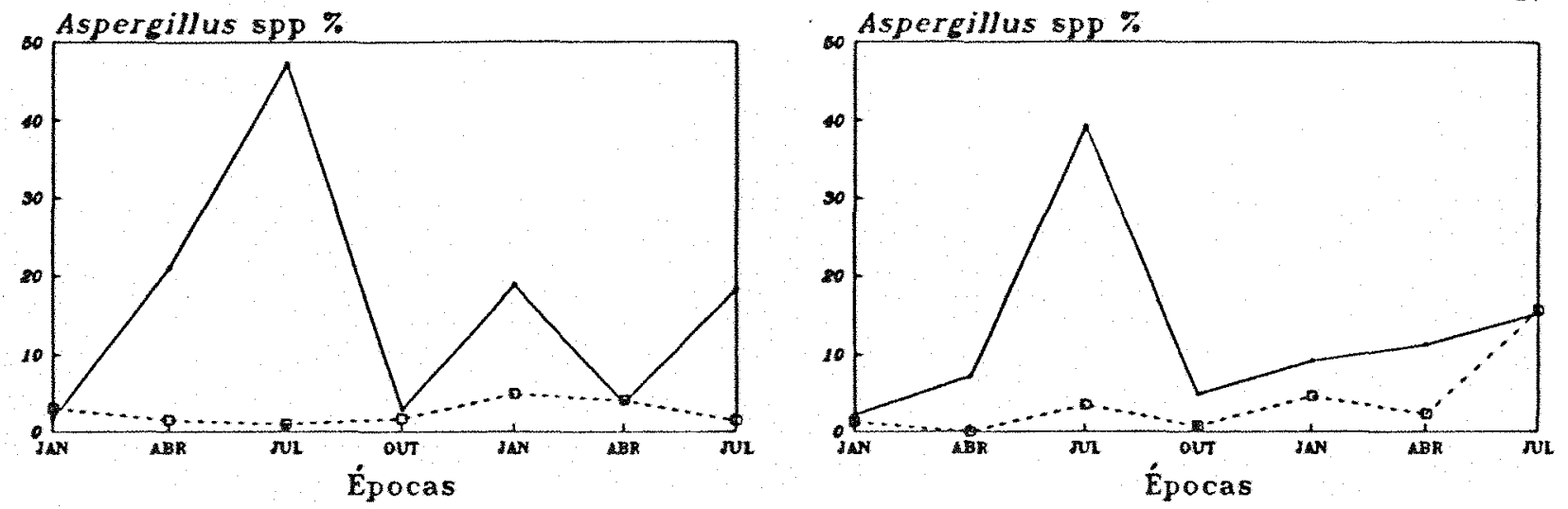

AMOSTRA 9

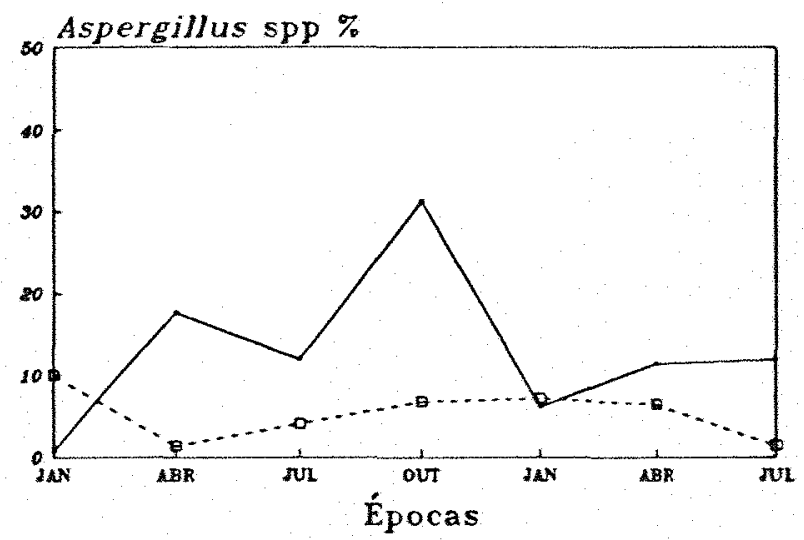

- MECÂNICO

AMOSTRA 11



AMOSTRA 10

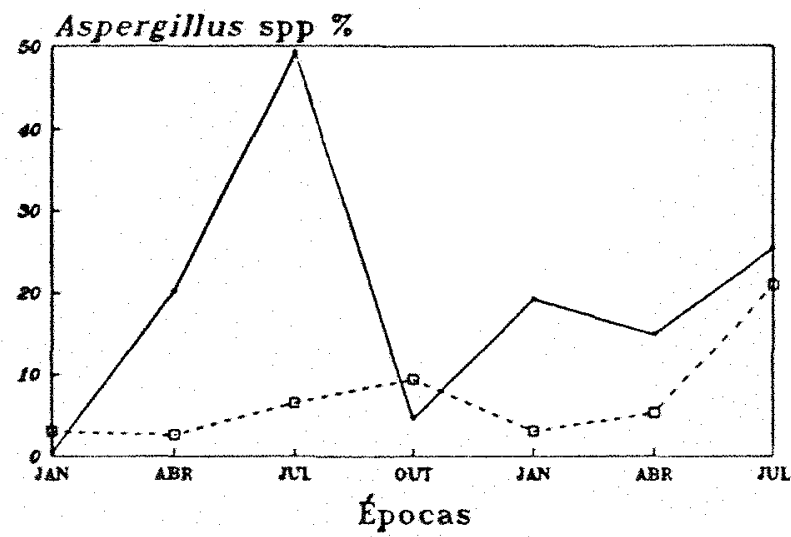

FLAMBAGEM

AMOSTRA 12

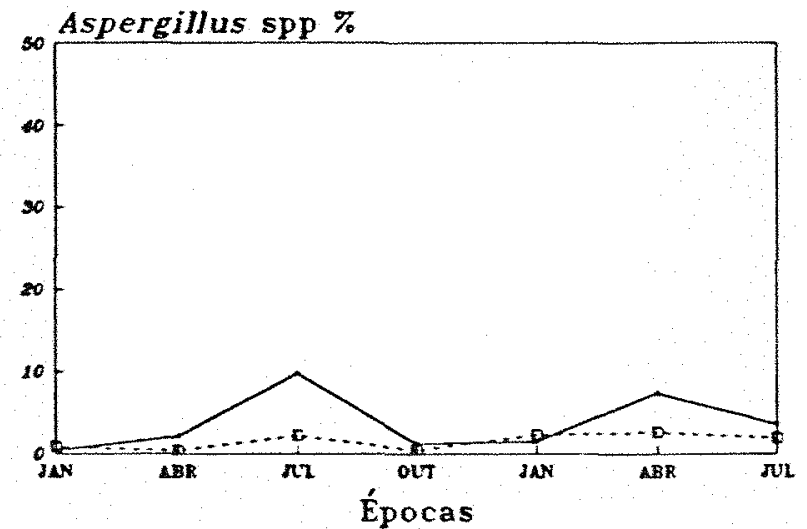

Figura 16. Incidência de Aspergillus spp. em em sementes de algodão, nas seis amostras da cultivar IAC-20, submetidas a dois tipos de deslintamento. durante 0 armazenamento por 18 meses em condicốes de ambiente não controlado. 
restrictus, A. glautus e Maldemia sebi. Em teores de água mais elevados, entre $14-15 \% \quad(75-80 \%$ de UR) proliferam $A$. candidus, A. ochraceus e para umidade entre $15-17 \%$ (80-85\% de UR) se desenvolvem os fungos anteriores e A. flaws e Paniclilium e para $17-19 \% \quad(85-90 \%$ de UR) os fungos anteriores (HALLOIN, 1986).

Pode ter ocorrido, também, uma sucessão de espécies de Asfergillus não detectada neste trabalho porque não se procedeu à identificacão de espécies do fungo. Em futuros trabalhos sobre armasenamento, devido à importancia de fungos do gênero Aspergillus na deterioracão de sementes, é interessante que a avaliaçăo seja feita a nivel de espécie, inclusive utilizando meios de cultura especificos para identificacão de fungos deste gênero. Utilizando meio malte-ágar com NaOCl a $10 \%$ em sementes de algodão, com ou sem desinfeccão superficial com cloreto de sódio, foram detectadas espécies de Asfergillus dos grupos Aspergillus flavus, Aspelgillus glaums, A. orhaters, A. bersicolor, A. niger, A. nidulans, além de fenicilliume alguns fungos de campo. Em algodão, ao contrário de outras espécies como soja e milho, estes fungos foram encontrados em quantidades semelhantes em sementes com e sem desinfectão, principalmente o fungo Aspergillus glausus, que normalmente é o primeiro a colonizar as sementes (WEIDENBORNER \& HINDORF, 1989) 


\subsubsection{Fenticillium SpP.}

Os resultados da incidência deste fungo nas sementes de algodão estão listados na Tabela 16.

Houve variacão na quantidade encontrada de Pentillium spp. nas diversas épocas de avaliafão. A incidencia inicial foi a mais baixa, havendo aumento a partir de abril de 1989. As sementes deslintadas mecanicamente apresentaram quantidades superiores deste microrganismo após janeiro de 1989.

Verificou-se, através do teste F de contraste entre as médias, que as amostras da cultivar IAC-20, com média de $5,44 \%$, apresentaram indices superiores de Penticillium spp. aos das amostras da cultivar IAC-19, com médi a de $3,14 \%$.

A incidência de fenicillium spP., tal como o microrganismo anterior, aumentou com $o$ decorrer da estocagem das sementes. Em abril e julho de 1989 foram encontrados os maiores indices. Na instalacão do experimento, a incidencia nas amostras variava entre 0,4 e $7,3 \%$. Em julho de 1989 os niveis nas sementes estavam entre 0,7 e $37,6 \%$. Notou-se que o coeficiente de variacão foi relativamente alto. Possivelmente, também, possa ter havido contaminação pelo ambiente, já que fungos dos gêneros Aspelgillus e fenicillium são frequentes no ambiente, a a 
metodologia empregada para avaliação não tenha sido a ideal para fungos de armazenamento.

As sementes flambadas, inicialmente, apresentaram incidências maiores do fungo, mas esta situacão se reverteu a partir de jultho de 1988 . Em abril e julho de 1989, os indices foram baixos para sementes flambadas e elevados para sementes deslintadas mecanicamente, possivelmente devido ao menor teor de umidade das primeiras (Fig. 17 e 18). Ocorreu, assim como para Aspergillus spp., uma flutuagão da presenca de Penicillium spp. nas sementes, ou porque a metodologia empregada não é a mais adequada ou por contaminação do ambiente, ou porque houve uma sucessão de espécies, com a morte de algumas e a substituicão por outras. Há, porém, uma tendência de aumento de Aspergillus e fenicillium em sementes durante o armazenamento (Tabelas 14 e 16 ).

Considerando-se a média de todas as amostras (Tabela 17), as sementes flambadas apresentaram menores incidências de Penicillium spp que as deslintadas mecanicamente. As amostras com maiores niveis do fungo foram 9, 10, 11 e a amostra com menor nivel foi a 12. 
Tabela 16. Incidência de Penteillium spp., durante o armazenamento por 18 meses em condicões de ambiente não controlado, em sementes de algodão (Método do papel de filtro, 7 dias de incubacão) submetidas a dois tipos de deslintamento. Resultados são médias de doze amostras de sementes.

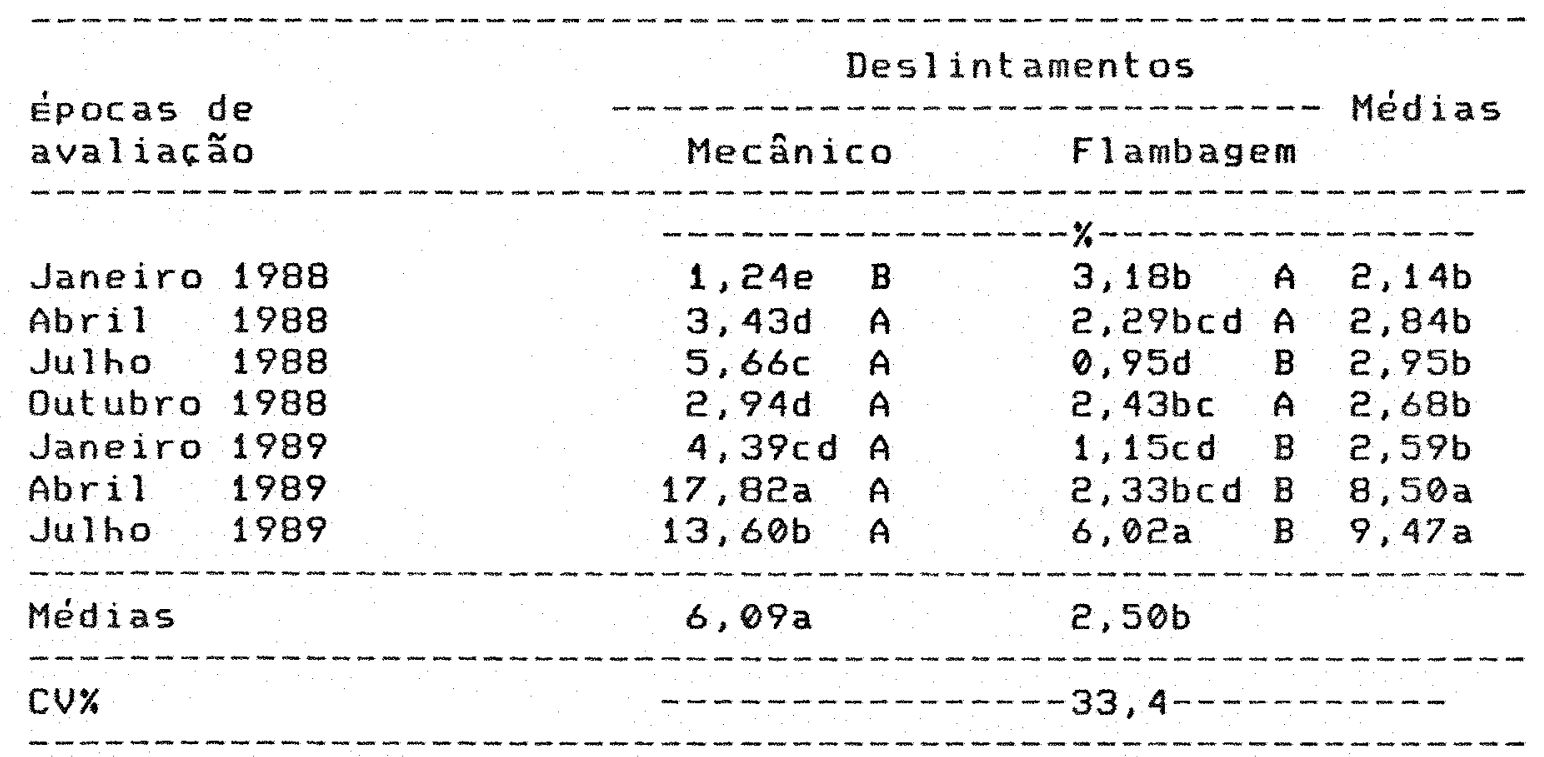

Letras minúsculas comparam medias na vertical e maiúsculas na horizontal.

Médias seguidas pela mesma letra não diferem entre si ao nivel de $5 \%$ de probabilidade pelo teste de Tukey. 
Tabela 17. Incidência média de Fenicillium spp. em sementes de algodão durante 18 meses de armazenamento sob condicôes de ambiente não controlado.



Letras minúsculas comparam médias na vertical e maiúsculas na horizontal.

Médias seguidas pela mesma letra não diferem entre si ao nivel de $5 \%$ de probabilidade pelo teste de Tukey. 

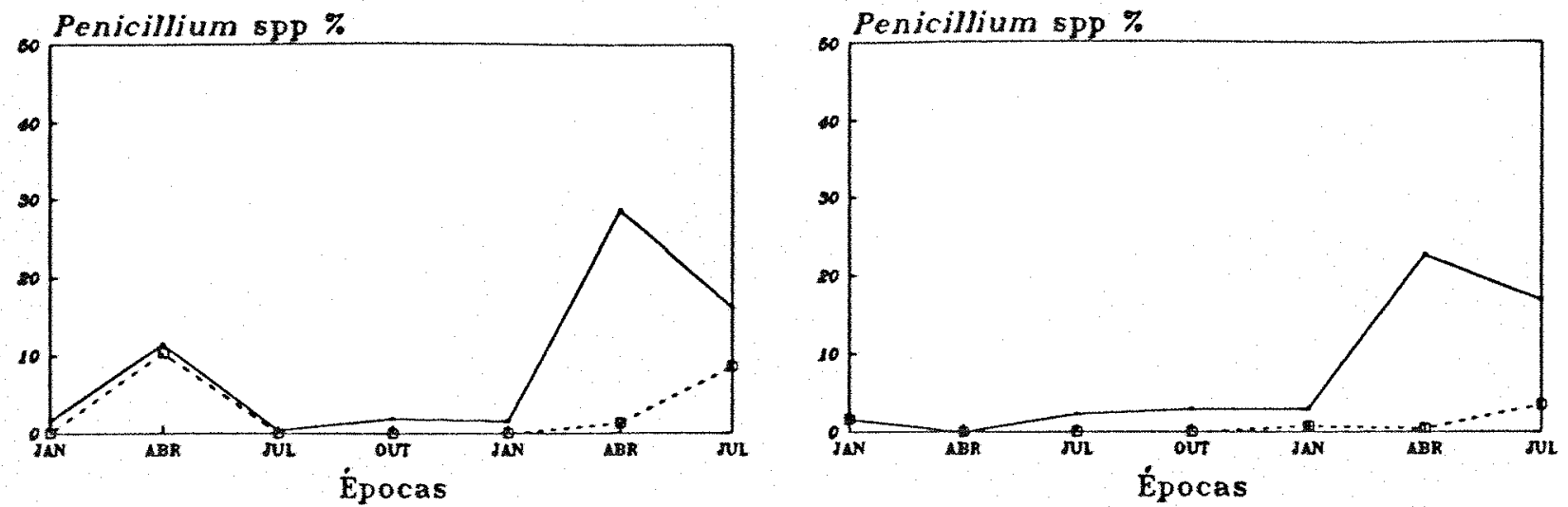

AMOSTRA 3

AMOSTRA 4


MECÂNICO

FLAMBAGEM

AMOSTRA 5

AMOSTRA 6
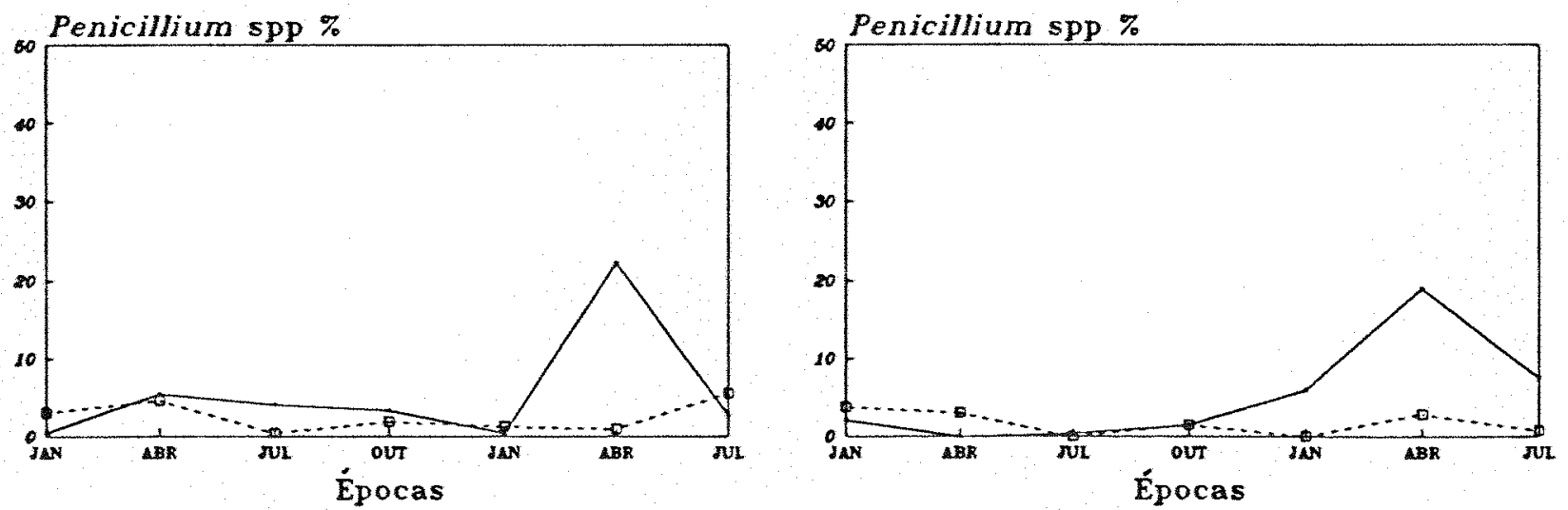

Figura 17. Incidencia de Penicillium spp. em sementes de algodão, nas seis amostras da cultivar IAC-19, submetidas a dois tipos de deslintamento, durante o armazenamento por 18 meses em condicões de ambiente não controlado. 

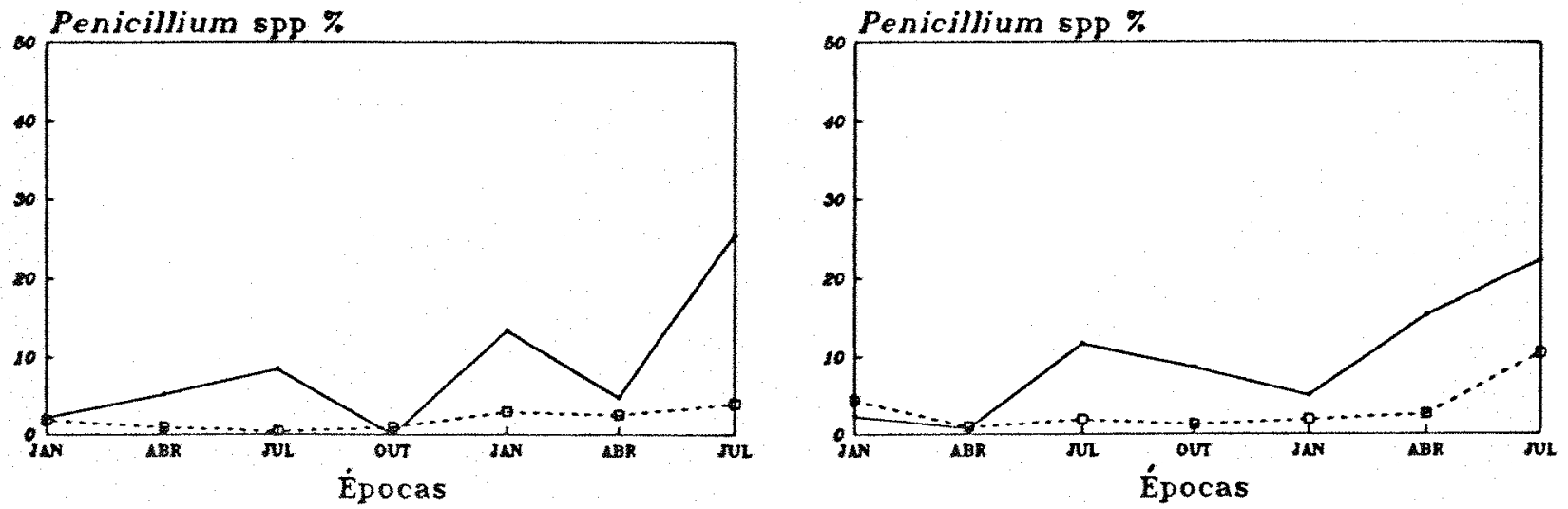

AMOSTRA 9

AMOSTRA 10

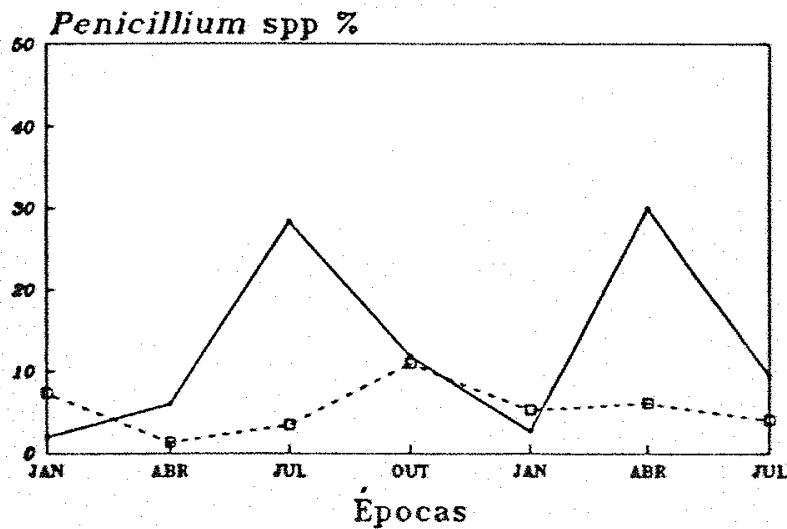

MECÂNICO



FLAMBAGEM

AMOSTRA 11

AMOSTRA 12
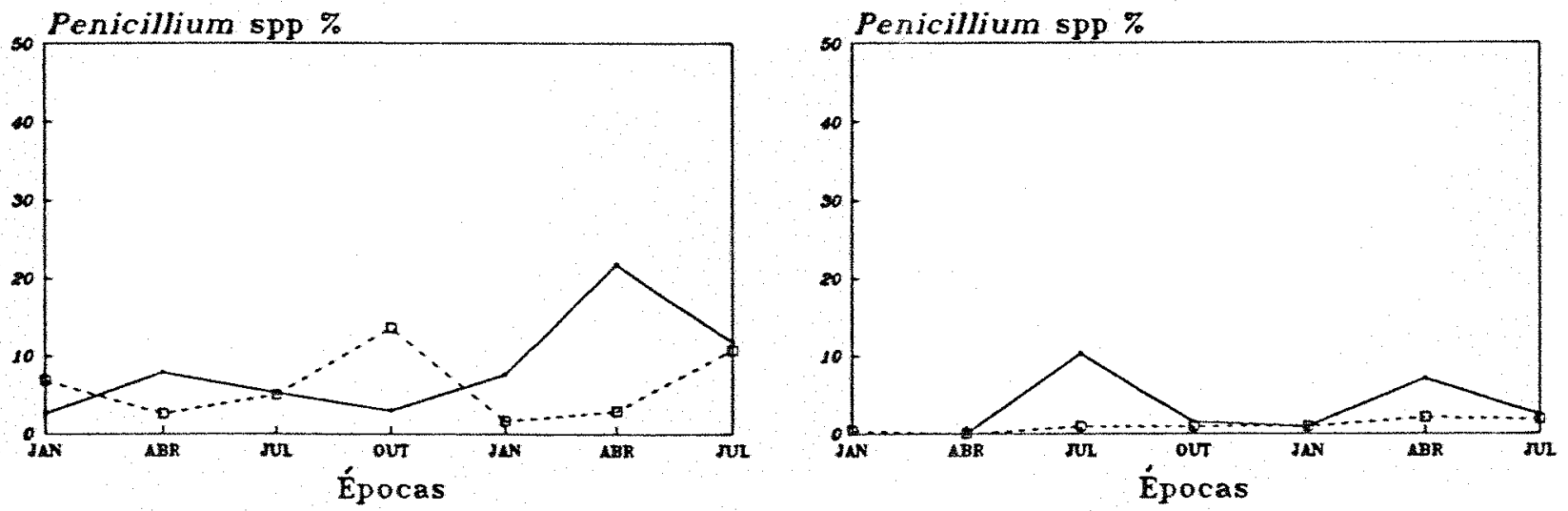

Figura 18. Incidência de fenicillium spp. em sementes de algodão, nas seis amostras da cultivar IAC-20, submetidas a dois tipos de deslintamento, durante 0 armazenamento por 18 meses em condifões de ambiente não controlado. 


\subsubsection{Discussão geral}

o principal efeito benéfico da flambagem foi a reducão na umidade das sementes, que se manteve durante os 18 meses de armazenamento. Como consequência, as sementes flambadas apresentaram resultados superiores de germinacão e vigor (emergência em areia) durante todo o periodo. As sementes flambadas também mostraram indices significativamente inferiores de Aspergillus spp. e Penicillium spP. e de fusarium sPP durante o armazenamento. Quanto ao vigor, medido pelo teste de envelhecimento acelerado, as sementes flambadas superaram as sementes deslintadas mecanicamente, mas a superioridade não foi tão nitida quanto para a germinacão logo após o deslintamento através da flambagem não houve diferenca quanto à incidência de fungos em sementes deslintadas mecanicamente e flambadas. Durante o armazenamento não ocorreram diferencas entre os tratamentos para a incidencia de C. gossypii e gotryodiflodia sp. Para Fusarium sp. o decréscimo na viabilidade foi mais acentuado em sementes flambadas. Aspelgillus spp. e fenteillium spp. se desenvolveram em maior intensidade em sementes deslintadas mecanicamente, provavelmente devido ao maior teor de água das mesmas.

Ocorreu decréscimo na germinação durante o armazenamento, que já era esperado devido a uma série de 
reacôes que ocorrem nas sementes durante o processo de deterioracão. 0 periodo de exposicão ao envelhecimento acelerado foi considerado muito longo, ocorrendo flutuacão nos resultados.

De uma maneira geral os fungos de campo tiveram a sua incidência reduzida durante 0 armazenamento. 0 decréscimo na incidência de $C$. gossypil foi mais rápido que - decréscimo na incidencia de Fusarium spp. Aspargillus 5pp. e fenicillium spp. apresentaram aumento de incidência durante o armazenamento.

Nấo foram encontradas correlacốes entre os parámetros avaliados neste trabalho (Tabela 18). Isto ocorreu possivelmente porque, em cada lote, durante o armazenamento, uma série de processos ocorrem simultaneamente, sendo dificil atribuir o decréscimo na viabilidade das sementes apenas a umas das variáveis avaliadas. 
Tabela 18. Katriz de correlacăo entre as variáveis germinaçăo, envelhecimento acelerado, umidade, e incidência de Colletotrichue gossypii, Botryodiplodia sp., Fusariu量 spp., Aspergillus spp. E Penicilliuin spp.

\begin{tabular}{|c|c|c|c|c|c|c|c|c|}
\hline Variáveis & Ger inarăo & $\begin{array}{c}\text { Envelhecinento } \\
\text { Acelerado }\end{array}$ & Unidade & $\begin{array}{l}\text { Colletotrichum } \\
\text { gossypii }\end{array}$ & $\begin{array}{c}\text { Botryodiplodia } \\
\text { sp. }\end{array}$ & $\begin{array}{c}\text { Fusariulu } \\
\text { spp. }\end{array}$ & $\begin{array}{c}\text { Aspergillus } \\
\text { spp. }\end{array}$ & $\begin{array}{c}\text { Penicillium } \\
\text { spp. }\end{array}$ \\
\hline Germinaçăo & 1,00 & 0,21 & 0,11 & 0,07 & 0,00 & 0,03 & 0,10 & 0,13 \\
\hline $\begin{array}{l}\text { Envelhecinento } \\
\text { Acelerado }\end{array}$ & - - & 1,00 & 0,11 & 0,09 & 0,01 & 0,04 & 0,05 & 0,16 \\
\hline Unidade & - & - & 1,00 & 0,21 & 0,01 & 0,01 & 0,06 & 0,02 \\
\hline $\begin{array}{l}\text { Colletotrichum } \\
\text { gossypii }\end{array}$ & - & - & - & 1,60 & 0,26 & 9,25 & 0,02 & 0,02 \\
\hline $\begin{array}{l}\text { Botryodiplodia } \\
\text { sp. }\end{array}$ & - & - & - & - & 1,00 & 0,17 & 0,02 & 0,00 \\
\hline $\begin{array}{c}\text { Fusariul } \\
\text { spp. }\end{array}$ & - & - & - & - & - & 1,60 & 0,00 & 0,00 \\
\hline $\begin{array}{l}\text { Aspergillus } \\
\text { spp. }\end{array}$ & - & - & - & - & - & - & 1,00 & 0,49 \\
\hline $\begin{array}{c}\text { Penicillium } \\
\text { spp. }\end{array}$ & - & - & - & - & - & - & - & 1,00 \\
\hline
\end{tabular}




\section{CONCLUSÕES}

Os resultados encontrados no presente trabalho permitiram a obtencão das seguintes conclusões:

I. D deslintamento adicional por flambagem, em relacão ao apenas mecânico, resultou em umidade significativamente menor nas sementes de algodão armazenadas durante 18 meses, maior germinação, emergência em areia, indice de envelhecimento acelerado, e niveis significativamente inferiores de fusallum SPP. Aspergillus spp. e fenicillium spp.

II. 0 efeito benéfico da flambagem foi significativo logo após os deslintamentos considerados, acentuando-se com o passar do periodo de armazenamento.

III. É provável que o efeito benéfico do deslintamento de sementes de algodão a flama, em relaçăo ao mecânico, quanto à germinacão, emergência em areia, envelhecimento acelerado e sanidade para Asfergillus spp. e Fenicillium spp. seja uma consequência da diminuifão da umidade.

IV. As incidências de colletotrichum gossypiti e de Botryodiflodia Sp. não foram afetadas pelo deslintamento a flama em relaçăo ao mecânico. 
V. Durante o armazenamento das sementes de algodão ocorreram decréscimos na germinacão, no vigor (emergencia em areia, envelhecimento acelerado) e incidências de $C$. gossypiti, fusarium spp. e fotryodiplodia sp.e acréscimos nas incidéncias de Aspergillus spp. e Fenicillium spp.

VI. A flambagem favoreceu a sanidade das sementes durante o armazenamento, reduzindo, ao longo do tempo, as incidências de Fusarium SPP., Aspelgillus spp. e Penicillium spP. 
REFERÉNCIAS BIBLI IOGRÁF ICAS

ARNDT, C.H. Infection of cotton seedlings by Colletotrichua gossypix as affected by temperature. Phytopathology, 5t. Paul, 34: 861-9, 1944.

ARNDT, C.H. Effect of storage conditions on survival of Colletotrichum gossypit. Phytopathology, st. Paul, 36 : $24-9,1946$.

ARNDT, C.H. Survival of Colletotrichum gossypit on cotton seeds in storage. Phytopathology, st. Paul, 43: 220. 1953.

ARNDT, C.H. Cotton seed produced in South Carolina in 1954 and 1955, its viability and infestation by fungi. Plant Disease Reporter, St. Paul, 40:1001-4, 1956.

BAGGA, H.S. Fungi associated with cotton boll rot and their frequency. Plant Disease Reporter, St. Paul, 52 : $582-4,1968$.

BAIN, D.C. Effect of sulfuric-acid treatment on fungi and bacteria present on cotton seed from diseased bolls. Phytopathology, 5t. Paul, 29: 874-9, 1934. 
BALMER, E.; SALgado, C. L.; CIA, E.; CAMPOS, H. Efeito do potencial de inóculo de Colletotrictum gossypiz south. sobre o tombamento das mudinhas de algodoeiro. Anais da Escola Superior de Agricultura "Luiz de Queiroz", Piracicaba, 23: $325-38,1966$.

BARTEE, S.N. \& KRIEG, D.R. Cottonseed density: associated fisical and chemical properties of 10 cultivars. Agronomy Journal, Madison, 66: 433-5, 1974.

BASKIN, C.C. Seed cotton storage. In: BELTWIDE COTTON PRDDUCTION RESEARCH CONFERENCE, New Orleans, 1981. Proceedings. Memphis, National Cotton Council of America, 1981. P. 306-8.

BISHNOI, U.R. \& DELOUCHE, J.C. Relationship of vigor tests and seed lots to cotton seedling establishment. Seed Science and Technology, Zurich, 8: $341-6,1980$.

BOCKHOLT, A.J.; ROGERS, J.S.; RICHMOND, T.R. Effects of various storage conditions on longevity of cotton, corn, and sorghum seeds. Crop Science, Madison, 9: 151-3, 1969.

BOLLENBACHER, K.; FULTON, N.D.; MCCUTCHEN B.E. Behavior of artificially deteriorated cottonseed after various storage periods. Agronomy Journal, Madison, 55: 521-3, 1963. 
BRASIL, Ministério da Agricultura. Regras para análise de sementes. Brasilia, 1980. 188p.

BUENO, J.T. Influência do genótipo e local de produção na incidência de fungos em sementes de algodoeiro (Gosgypium hirsutum L.) no Estado do Paraná. Piracicaba, 1986. (Mestrado - Escola Superior de Agricultura "Luiz de Queiroz"/ USP).

CHESTER, K.S. Field results with gravity cottonseed. Phytopathology, St. Paul, 30:703, 1940.

CIA, E. Ocorrência e conhecimento das doencas do algodoeiro anual bossypium hirsutum L. no Brasil. Summa Phytopathologica, Piracicaba, 3: 167-93, 1977.

CIA, E.; RODRIGUES FILHO, F.5.0,; SOAVE, J. Efeito de tratamentos com fungicidas na conservacão de sementes de algodoeiro (Gossgpium hirsutum L.). Bragantia, Campinas, $39: 59-67,1980$.

COLYER, P.D. Frequency and pathogenicity of Fusarium sPP. associated with seedling diseases of cotton in Louisiana. Plant Disease, 5t. Paul, 72(5): 400-2, 1988.

DELOUCHE J.C. Harvest and post harvest factors affecting the quality of cotton planting seed and seed quality evaluation. In: BELTWIDE COTTON PRODUCTION RESEARCH 
CONFERENCE, New orleans, 1981. Proceedings. Memphis, National Cotton Council of America, 1981. P. 289-305.

DELOUCHE, J.C. \& BASKIN, C.C. Vigor determines performance of cottonseed. Cotton International Edition, London, $27: 65-70,1970$.

DELOUCHE, J.C. \& BASKIN, C.C. Accelerated aging techniques for predicting the relative storability of seed lots. Seed Science and Technology, Zurich, 1: 427-52, 1973.

DHARMALINGAM, C. \& BASU, R.N. Control of seed deterioration in cotton (Gossyfium hilsutum L.). Current Science, Columbus, 47: 484-7, 1978.

FERRAZ, C.A.M.; RODRIGUES FILHO, F.S.0.; CIA, E.; SABINO, N.P.; VIEGA, A.A.; REIS, A.J.; ORTOLANI, D.B. Estudo comparativo de métodos de deslintamento de sementes de algodoeiro (Gossyfium hirsutum L.) em condicões de campo. Bragantia, Campinas, 36:11-2, 1977.

GELMOND, H. Relationship between seed size and seedling vigour in cotton (Gassspium hirsutum L.). Proceedings of the International Seed Testing Association, Zurich, $37(3): 797-802,1972$.

GELMOND, H. A review of factors affecting seed quality distinctive to cotton seed production. Seed science and Technology, Zurich, 7: 39-46, 1979. 
GERALDI, M.A.P. Sanidade de sementes de algodoeiro. In: IV CONGRESSO PAULISTA DE FITOPATOLOGIA, Campinas, 1981. Resumos. Summa Phytopathologica, Piracicaba, 6(2): 1213, 1981

HALLOIN, J.M. Postharvest infection of cottonseed by Ahizopus arhizus, Aspergillus niger and Aspergillus flawus. Phytopathology, St. Paul, 65: 1229-32, 1975.

HALLOIN, J.M. Weathering: changes in planting seed quality between ripening and harvest. In: BELTWIDE COTTON PRODUCTION RESEARCH CONFERENCE, New Orleans, 1981. Proceedings. Memphis, National cotton Council of America, 1981a. P. 286-9.

HALLOIN, J.M. Deterioration of cottonseed during weathering and accelerated aging: the role of microrganisms. In: BELTWIDE COTTON PRODUCTION RESEARCH CONFERENCE, New Orleans, 1981. Proceedings. Memphis, National Cotton Council of America, $1981 \mathrm{~b}$. p.29.

HALLOIN, J.M. Microrganisms and seed deterioration. In: HORNER, E.S: KRAL, D.M.; MICKELSON, S.H., ed. Physiology of seed deterioration. Madison. Crop Science Society of America, 1986. p.89-99. 
HOFMANN, W.C.; KITTOCK, D.L.; ALEMAYEHU, M. Planting seed density in relation to cotton emergence and yield. Agronomy Journal, Madison, 80:384-6, 1988.

JOHNSON, J.R.; BASKIN, C.C.; DELOUCHE, J.C. Relation of bulk density of acid delinted cottonseed to field performance. Proceedings of the Association of official Seed Analists, Geneve, 63: 63-6, 1973.

KIMATI, H. Doencas do algodoeiro. In: GALLI, F., coord., Manual de fitopatologia. São Paulo, Editora Agronômica Ceres, $1980, v$. 2. Doencas das plantas cultivadas, p.2947.

KRIEG, D.R. \& BARTEE, S.N. Cottonseed density: associated germination and seedling emergence properties. Agronomy Journal, Madison, $67: 343-7,1975$.

LAGO, A.A. Testes de armazenabilidade para sementes de algodão. Revista Brasileira de Sementes, Brasilia, $7(2): 63-84,1985$.

LEFFLER, H.R. Developmental aspects of cotton seed planting quality. In: BELTWIDE COTTON PRODUCTION RESEARCH CONFERENCES, New Orleans, 1981. Proceedings. Memphis, National Cotton Council of America, 1981.P. $283-6$ 
LIMA, E.F.; CARUALHO, J.M.F.C.; CARUALHO, L.P. Sobrevivencia de colletotrichum gossypit var cephalosporioides em sementes de algodoeiro. Fitopatologia Brasileira, Brasilia, 13: 247-8, 1988.

LIMA, E.F.; CARUALHO, L.P. \& CARUALHO, J.M.F.C. Comparagão de métodos de análise sanitária e ocorrência de fungos em sementes de algodoeiro. Fitopatologia Brasileira. Brasilia, 7: 401-6, 1982 .

LIMA, E.F.; UIEIRA, R.M.; CARUALHO, J.M.F.C. Influência de Fhizopus sp., Aspergillus niger e A. flaws na deterioracão de sementes de algodoeiro armazenadas. Fitopatologia Brasileira, Brasilia, 9: 555-60, 1984.

LIMA, E.F.; CaRualho, J.M.F.C.; CARUalHo, L.P.; Costa, J.N. Transporte e transmissibilidade de colletotrichum gossgpil var. cephalosporioides através da semente do algodoeiro. Fitopatologia Brasileira, Brasilia, 10 : $105-15,1985$

LUWIG, C.A. Studies of antracnose infection in cottonseed. Phytopathology, 5t. Paul, 14: 52, 1924.

MCCARTER, S.M.; RONCADORI, R.W.; CRAWFORD, J.L. Microrganisms associated with cotton boll rots in Georgia. Plant Disease Reporter, St. Paul, 54(7): 58690,1970 . 
MAEDA, J.A.; LAGO, A.A.; ZINK, E.; RODRIGUES FILHO, F.S.D.; FERRAZ, C.A.M.; KRIZANOUSKI, F.C. Germinąão de sementes de algodão preparadas por diferentes métodos. Bragantia, Campinas, 36: 253-8, 1977.

NEERGARD, P. Seed pathology. London, Macmillan. 1977, $839 p$.

NOGLE, G.R. Cotton seed quality. Cotton Growing Review, London, 50: 43-62, 1973.

OTAZÚ, C.S.I. Efeito de métodos de deslintamento sobre o comportamento de sementes de algodão Gossypium hirsutum L.) no armazenamento. Piracicaba, 1986. (Mestrado Escola Superior de Agricultura "Luiz de Queiroz"/ USP).

PATE, J.B. \& DUNCAN, E.N. Viability of cottonseed after long periods of storage. Crop Science, Madison, 4: 342$343,1964$.

PERRY, D.A. ed. Handbook of vigour test methods. Zurich, International Seed Testing Association, 1981.72p.

PIZZINATTO, M.A. Relacão entre densidade e qualidade de sementes de algodoeiro cbossypium hilsutum L var latifolium HUTCH.) e patogenicidade de Fusarium spp. LINK ex FR. Piracicaba, 1988. (Doutorado - Escola Superior de Agricultura "Luiz de Queiroz"/ USP). 
PizzinatTo, M.A. \& MENTEN, J.o.M. Reacão de macãs de algodoeiro a oito espécies de Fusarium isoladas de sementes. Fitopatologia Brasileira, Brasilia, 15: 33-7. 1990.

Pizzinatto, M.A.; soave, J.; CiA, E. Patogenicidade de Botryodiplodia theobromae pat. a plantas de diferentes idades e macãs de algodoeiro (Gossypium hirsutum L.). Fitopatologia Brasileira, Brasilia, 8: 223-9, 1983a.

Pizzinatto, M.A.; SDAve, J.; CiA, E. Levantamento de patógenos em sementes de seis cultivares de algodoeiro em diferentes localidades do Estado de São Paulo. Fitopatologia Brasileira, Brasilia, 9: 101-9, 1984.

PIZZINATTO, M.A.; SOAVE, J.; CIA, E.; MAEDA, J.A. Relacão entre presenca de patógenos, densidade e qualidade de sementes de algodoeiro (Gossgfium hirsutum L.). In: VI CONGRESSO PAULISTA DE FITOPATOLOGIA, Araras, 1983. Resumos. Summa Phytopathologica, Piracicaba, $9(1,2)$ : $47-8,1983 b$.

RAY, W.W. \& MCLAUGHLIN, J.H. Isolation and infection tests with seed and soilborne cotton pathogens. Phytopathology, St. Paul, 32: 233-8, 1941.

RDDRIGUES FILHO, F.S.0.; LAGO, A.A.; CIA, E.; FERRAZ, C.A.M. Conservacão de sementes de algodoeiro 
deslintadas por diferentes métodos. Bragantia, Campinas, $38: 107-13,1979$.

RONCADORI, R.W.: MCCARTER, S.M.; CRAWFORD, J.L. Influence of fungi on cotton seed deterioration prior to harvest. Phytopathology, st. Paul, 61: 1326-8, 1971.

Ross, E.E. Precepts of successful seed storage. In: HORNER, E.S: KRAL, D.M. \& MICKELSON, S.H., ed. Physiology of seed deterioration. Madison, Crop Science Society of America, 1986. P.1-25.

SANTIAGO, I.M. Influência do deslintamento à flama e químico sobre a germinacão, o vigor, e desempenho no campo de sementes de algodoeiro (Gossypiam hirsutum L.). Piracicaba, 1978. (Mestrado - Escola Superior de Agricultura "Luiz de Queiroz"/ USP).

SILUA, J.M.M. Efeito de métodos de deslintamento na germinacão e vigor de algodoeiro. Piracicaba, 1977. SMestrado - Escola Superior de Agricultura "Luiz de Queiroz"/ USP).

SIMPSON, D.M. Relation of moisture content and method of storage to deterioration of cottonseed. Journal of Agricultural Research, Madison, 50(5): 449-56, 1935. 
SIMPSON, D.M. The longevity of cottonseed as affected by climate and seed treatments. Journal of the American Society of Agronomy, Madison, 38: $32-45,1946$.

SIMPSON, D.M. Long-time storage of cottonseed. Agronomy Journal, Madison, 49: 608-609, 1957.

SIMPSON, D.M. \& WILSON, R.E. The relation of atmosferic humidity to moisture in cottonseed. Journal of the American Society of Agronomy, Madison, 35: 957-959, 1944.

SIMPSON, M.E.; MARSH, P.B.; MEROLA, G.V.; FERRETI, R.J.; FILSINGER, E.C. Fungi that infect cottonseeds before harvest. Applied Microbiology, Maryland, 26: 608-613, 1973.

SOAVE, J. Diagnóstico da patologia de sementes de algodoeiro no Brasil. Revista Brasileira de Sementes, Brasilia, $7(1): 195-200,1985$

STEWART, J. MCD. \& DUNCAN, E.N. Cottonseed viability after long-time storage. Agronomy Journal, Madison, 68: 243$244,1976$.

TANAKA, M.A.S. Patogenicidade e transmissão por sementes do agente causal da ramulose do algodoeiro. Piracicaba, 1990. (Doutorado - Escola Superior de Agricultura "Luiz de Queiroz"/ USP). 
TANAKA, M.A.S. \& PAOLINELLI, G.P. Avaliacão sanitäria e fisiológica de sementes de algodão produzidas no Estado de Minas Gerais. Fitopatologia Brasileira, Brasilia, $6(1): 71-81,1984$

TODLE, E.H. \& DRUMOND, P.L. The germination of cottonseed. Journal of Agricultural Research, Madison, 28(3): 28596. 1924 .

USBERTI, R. Determinação do potencial de armazenamento de amostras de sementes de algodoeiro. Revista Brasileira de Sementes, Brasilia, 6: 11-23, 1984.

WANJURA, D.F; HUDSPETH Jr., E.B. \& BILBRO Jr. J.D. Emergence time, seed quality, and planting depth effects on yield and survival of cotton (Gossypium hirsutum L.). Agronomy Journal, Madison, 61: 63-5, 1969.

WATKINS, G.M. Compendium of Cotton Diseases. St. Paul, The American Phytopathological Society, 1981.87p.

WEIDENBORNER, W. \& HINDORF, H. Fungi isolated from protein enriched seeds and pods with special emphasis on the genus Aspergillus. Seed Science and Technology, Zurich, $17(2): 383-9,1989$. 
WILKES, L.H. Seed cotton storage: effects on seed quality. In: BELTWIDE COTTON PRODUCTION RESEARCH CONFERENCE, Dallas, 1978. Proceedings. Memphis, National Cotton Council of America, 1978. P.215-7. 